\title{
Evaluating and Prioritizing Stream Restoration in Mined Appalachian Watersheds.
}

\author{
Eric Mitchell Miller
}

Follow this and additional works at: https://researchrepository.wvu.edu/etd

Part of the Environmental Health and Protection Commons, Natural Resources and Conservation Commons, and the Natural Resources Management and Policy Commons

\section{Recommended Citation}

Miller, Eric Mitchell, "Evaluating and Prioritizing Stream Restoration in Mined Appalachian Watersheds." (2015). Graduate Theses, Dissertations, and Problem Reports. 8169.

https://researchrepository.wvu.edu/etd/8169

This Dissertation is protected by copyright and/or related rights. It has been brought to you by the The Research Repository @ WVU with permission from the rights-holder(s). You are free to use this Dissertation in any way that is permitted by the copyright and related rights legislation that applies to your use. For other uses you must obtain permission from the rights-holder(s) directly, unless additional rights are indicated by a Creative Commons license in the record and/ or on the work itself. This Dissertation has been accepted for inclusion in WVU Graduate Theses, Dissertations, and Problem Reports collection by an authorized administrator of The Research Repository @ WVU.

For more information, please contact researchrepository@mail.wvu.edu. 


\title{
Evaluating and Prioritizing Stream Restoration in Mined Appalachian Watersheds
}

\author{
Eric Mitchell Miller \\ Dissertation Submitted to the \\ Davis College of Agriculture, Natural Resources, and Design \\ At West Virginia University \\ In partial fulfillment of the requirements for the degree of
}

Doctor of Philosophy
In

Forest Resources Science

J. Todd Petty, Ph.D., Chair
James T. Anderson, Ph.D.
Michael P. Strager, Ph.D.
Leslie Hopkinson, Ph.D.
Paul F. Ziemkiewicz, Ph.D.

School of Natural Resources

Morgantown, WV

2015

Keywords: Little Coal River, Stream Restoration, Natural Channel Design, West Virginia, In-Stream Structures

Copyright 2015 Eric Mitchell Miller 


\begin{abstract}
Evaluating and Prioritizing Stream Restoration in Mined Appalachian Watersheds
\end{abstract}

\title{
Eric Miller
}

The state of West Virginia requires stream mitigation to offset anthropogenic impacts to streams; consequently there is a high concentration of mitigation projects in the mountaintop mining/valley fill region. Projects are typically outside mine boundaries and sites are selected at the discretion of the West Virginia Department of Environmental Protection. This dissertation evaluated current in-stream, natural channel design (NCD) structures and prioritized future project locations. First, we assessed the Little Coal River, which is one of the largest physical restoration projects in the state. The Little Coal drains $994 \mathrm{~km}^{2}$ with extensive historic and contemporary coal mining. The objectives of our study were to quantify the effects of in-stream structure construction on stream channel morphology, fish habitat quality, sediment composition, bank stability, fish, and macroinvertebrate assemblages and to determine the extent to which benefits persisted over our study period ( 5 years). Our results indicate that the beneficial effects of structures include: improved fish habitat quality, increased bed complexity, and increased substrate diversity. Post-construction fish habitat quality and streambed complexity, although dynamic, appear to be relatively stable over time. We observed significant localized macroinvertebrate response to restoration that was mediated by shifts from sand dominated substrates to cobble and gravel. However, overall improvements to invertebrate assemblages at the river reach scale were not observed, because restoration did not affect substrate composition at the larger scale. In contrast, we did observe reach-scale effects of restoration on fish assemblages. However, the overall response was difficult to interpret as being ecologically beneficial or not. Total fish biomass, total abundance, and sucker abundance increased in response to NCD structure construction. Fish species richness and integrity measures remained unchanged, and gamefish abundance decreased on the Little Coal River. Second, we expanded our region and assessed the biological and physical responses to 14 restoration projects in an intensively mined region. Our results suggest that typical restoration practices consistently improve physical habitat quality regardless of drainage area. Restored reaches generally have higher habitat condition scores than adjacent reference reaches and tend to be higher than the average reach in the region. In contrast, macroinvertebrate assemblages demonstrated no measurable positive response to physical habitat restoration, regardless of drainage area, water quality, or the condition of neighboring streams. Fish assemblage response to restoration was strongly context dependent. Restoration projects on smaller streams (i.e. $<50 \mathrm{~km}^{2}$ drainage area) with lower electrical conductivity $(<1000 \mu \mathrm{s} / \mathrm{cm})$ tended to result in a more positive response by fishes than projects on small, highly conductive streams. 
However, the most consistent response by fishes to restoration was an increased abundance and biomass of tolerant taxa. 


\section{Acknowledgments}

I dedicate my dissertation to my dad. Although he was not around to see this to the end, I know he was proud of me and I couldn't have done it without his love and support. I thank Dr. Todd Petty for his patience, insight, and mentorship during my time at WVU. Also, I thank my committee, Dr. Jim Anderson, Dr. Mike Strager, Dr. Leslie Hopkinson, and Dr. Paul Ziemkiewicz for providing me instruction and advice along the way. I thank the West Virginia Department of Environmental Protection and Dennis Stottlemyer for their assistance and funding my research.

I thank the great group of friends I have made along the way that have helped me in the field and in the lab. Eric Merriam and Alison Anderson have become true lifelong friends and I am so glad we had this journey together. A special thanks to Donna Hartman, Andy Maraffa, Brock Huntsman, and Michael Tincher for all their help. I also thank Dr. George Merovich for not only what he has done for me, but what he has done for everyone in our department. I am forever indebted to him for his selflessness and willingness to help.

I thank my mom and brothers for always being there for me. Also my extended family for supporting me and questioning me every Christmas on whether I was ever going to graduate. I would like to thank Mary Burger, she has been my rock my entire time in graduate school and I am forever thankful for everything she has done for me. 


\section{Table of Contents}

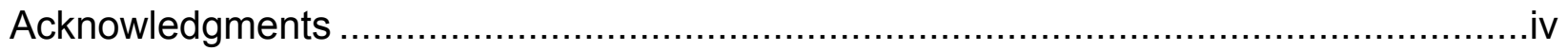

CHAPTER1: STREAM RESTORATION IN A LARGE, INTENSIVELY MINED APPALACHIAN RIVER: PHYSICAL BENEFITS AND STABILITY ............................... 1

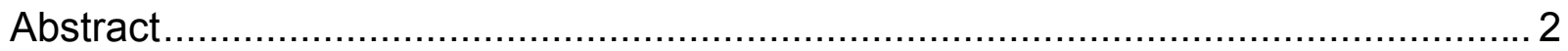

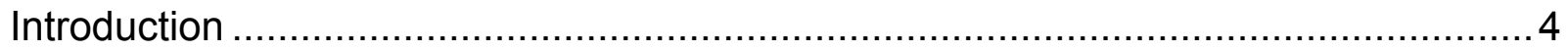

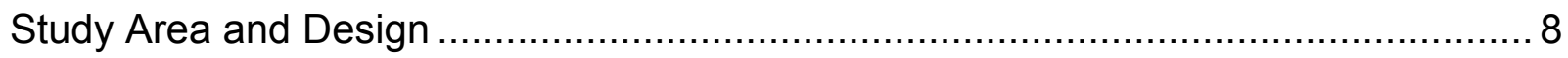

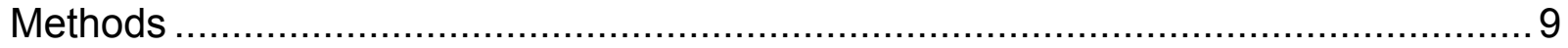

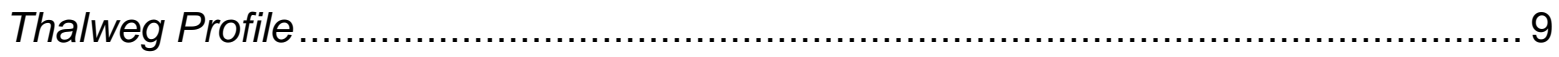

Substrate Composition and Water Depth .................................................... 10

Cross-Sectional Channel and Longitudinal Profile Geometry ............................... 11

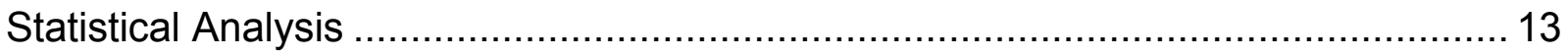

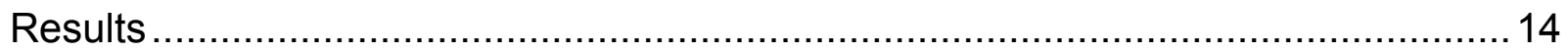

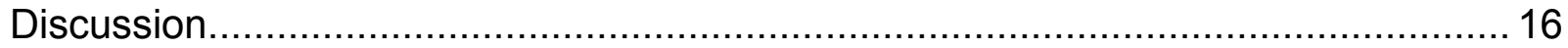

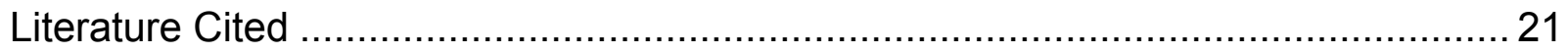

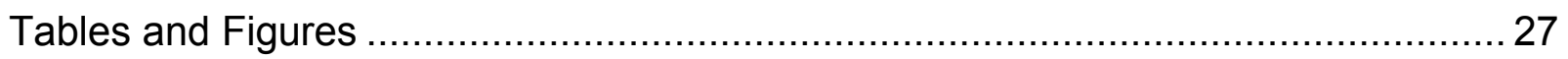

CHAPTER 2: STREAM RESTORATION IN A LARGE, INTENSIVELY MINED APPALACHIAN RIVER: MACROINVERTEBRATE AND FISH ASSEMBLAGE

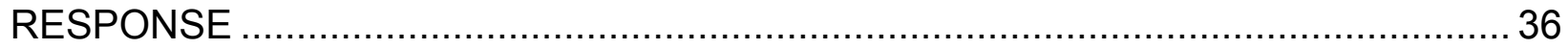

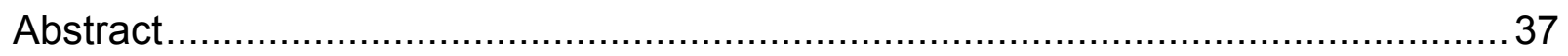

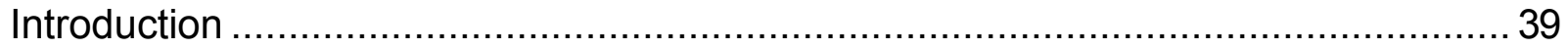

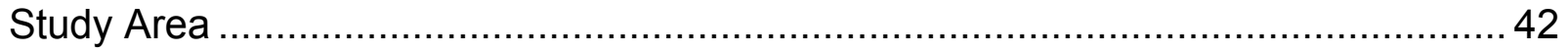

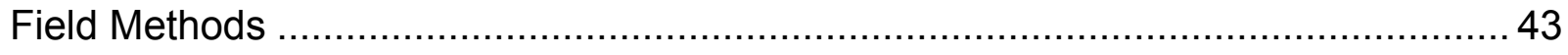

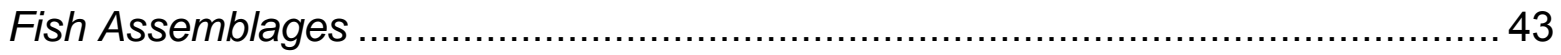

Benthic Macroinvertebrate Assemblages and Water Quality .............................. 44

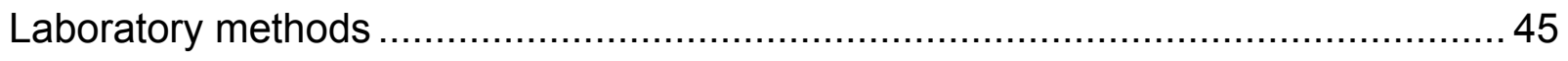

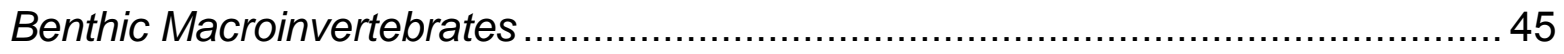

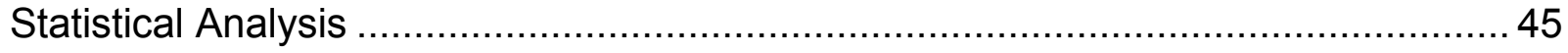

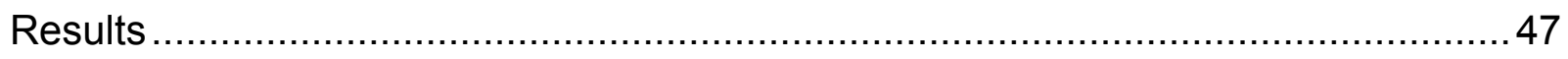

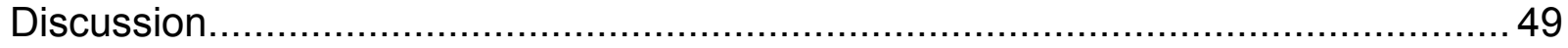




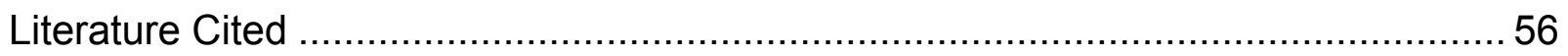

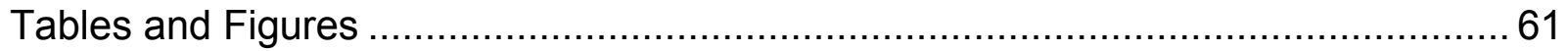

CHAPTER 3: CONTEXT-DEPENDENT EFFECTIVENESS OF STREAM

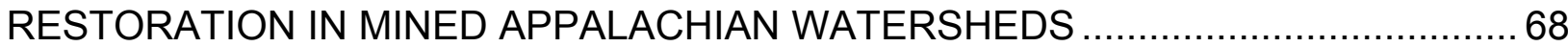

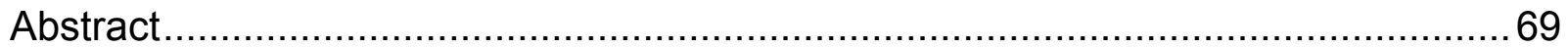

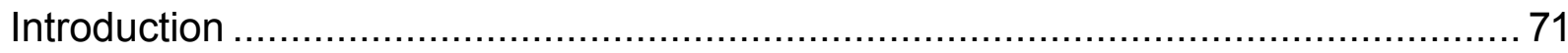

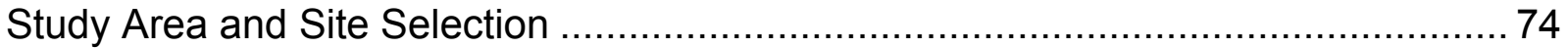

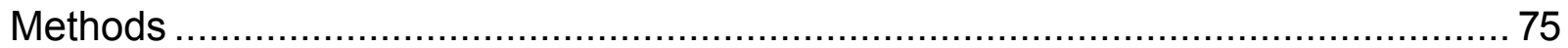

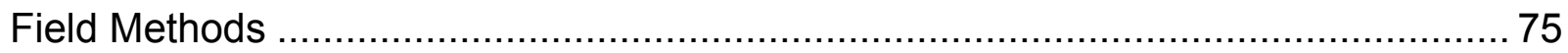

Rapid visual Habitat Assessment and Water Quality .......................................... 75

Benthic Macroinvertebrate Assemblages ....................................................... 76

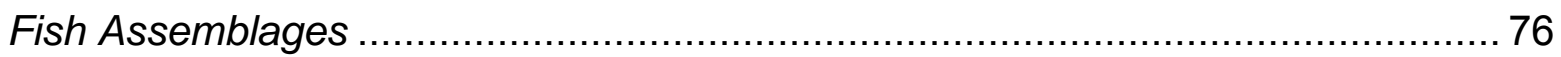

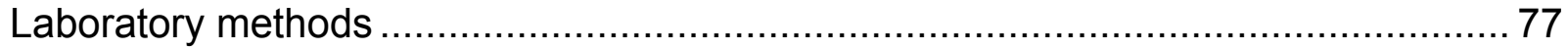

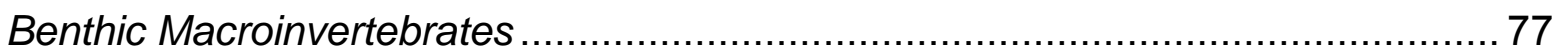

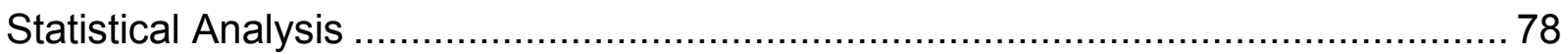

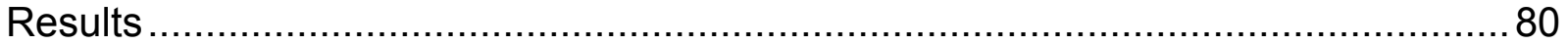

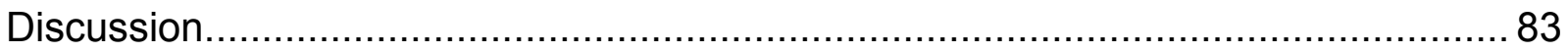

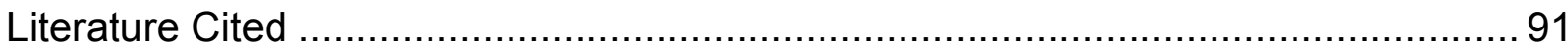

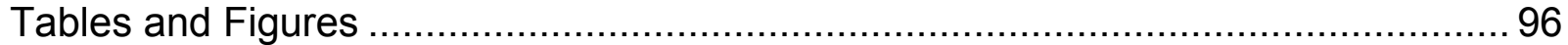

CHAPTER 4: BENEFITS AND LIMITATION OF STREAM RESTORATION IN THE MOUNTAINTOP MINING REGION OF WEST VIRGINIA ................................... 104

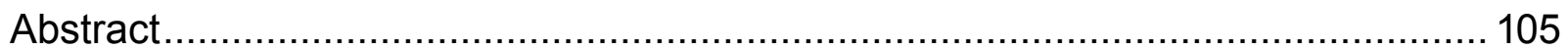

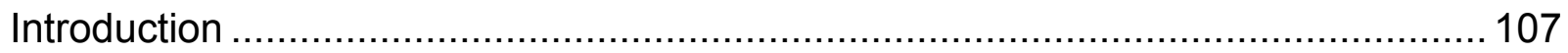

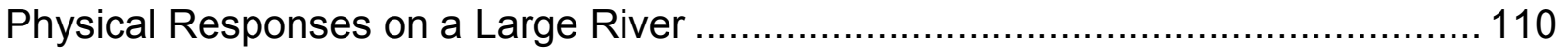

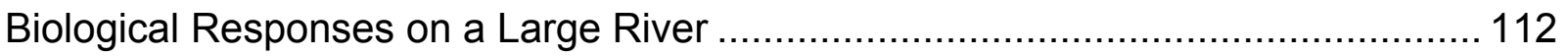

Physical Responses Over a Range of Drainage Areas and Water Qualities .......... 114

Biological Responses Over a Range of Drainage Areas and Water Qualities ......... 115

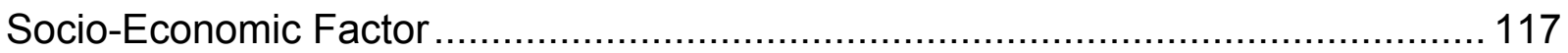

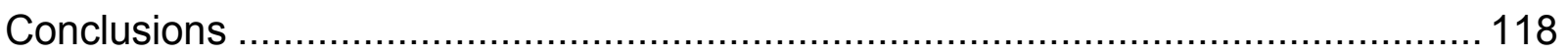

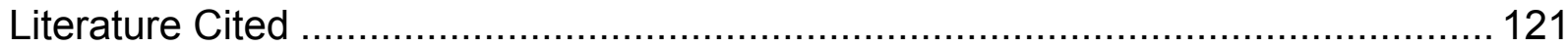

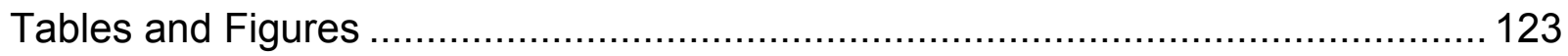


Appendix A: Cross sectional surveys of the upper, middle, and lower reaches. 
CHAPTER1: STREAM RESTORATION IN A LARGE, INTENSIVELY MINED APPALACHIAN RIVER: PHYSICAL BENEFITS AND STABILITY

Eric Miller* and J. Todd Petty

School of Natural Resources, West Virginia University, Morgantown, WV 26506

*Corresponding Author: Emiller9@mix.wvu.edu 


\section{Abstract}

Large-scale surface mining in the central Appalachians causes significant alteration of headwater catchments, and these impacts may be offset through implementation of stream restoration projects. For example, several natural channel design (NCD) structures (cross-vanes and j-hooks) were constructed along a $13.7 \mathrm{~km}$ section of the Little Coal River, West Virginia to mitigate regional mining impacts. The Little Coal River is a large river in Southern West Virginia that drains $994 \mathrm{~km}^{2}$ with extensive historic and contemporary coal mining. The objectives of our study were to quantify the effects of NCD structure construction on stream channel morphology, fish habitat quality, sediment composition, and bank stability, and to determine the extent to which benefits to physical habitats persisted over our study period (5 years). The study employed a before-after control-impact (BACl) design, included three $\sim 1 \mathrm{~km}$ segments along the Little Coal River mainstem, and included seasonal samples (Spring, Summer and Fall) from 2009-2013. BACl incorporates before (pre-construction or baseline) and after (post-construction) conditions, as well as a control (reference or unrestored area) with the impact site (restoration site). Our results indicate that the beneficial effects of structures include: improved fish habitat quality, increased bed complexity, and increased substrate diversity. Post-construction fish habitat quality and streambed complexity, although dynamic, appear to be relatively stable over time. There were localized shifts in substrate associated with the construction of mitigation structures. However, investigating the river at the reach scale showed no benefit of reducing sand substrate. Substrate composition was highly variable year-to-year and strongly dependent on river flow regimes. We found depth and complexity decreasing in the 
upper reach, which may be a sign of failure and aggregation. We suggest further monitoring and the possibility of a maintenance plan. Our results suggest that habitat enhancement projects on larger Appalachian streams, such as the Little Coal River, have potential for improved fish habitat conditions and streambed complexity that persist over time.

Key words: Stream mitigation, Natural Channel Design, In-stream structures, Mountaintop removal and valley fill mining, longitudinal profiles, Central Appalachia. 


\section{Introduction}

Stream restoration is a rapidly growing enterprise worldwide, with over a billion dollars spent annually in the United States (US) alone (Palmer et al. 2007). This expansion is largely due to natural stream channel restoration projects being used as mitigation for impacts of anthropogenic development activities to stream ecosystems (Simon et al. 2007). Since stream restoration is used throughout the US as mitigation for different impacts, it is not surprising that projects are diverse in application and objectives. For example, Brown (2000) found over 24 different stream restoration practices ranging from bank protection, grade control, and flow deflection, in the Baltimore, Maryland / District of Columbia area alone. Additionally, Bash and Ryan (2002) surveyed restoration project managers and found extremely diverse sets of goals, including: increased stream health, restored fish habitat and abundance, restored riparian zone condition, increased public awareness, increased funding for stream conservation, and simply to meet legal requirements. Nevertheless, one of the most common methods for physical stream restoration throughout the world is the construction of hard engineered structures with the goals of increasing streambed complexity, aquatic habitat, and biodiversity (Brown 2000, Bash and Ryan 2002, Palmer et al. 2014). These structures are typically cross-vanes and J-hooks which are comprised of natural materials and designed to narrow the river and reduce bank stress.

With the expanding number of and diversity of stream restoration projects, there is a critical need to assess the effectiveness of restoration and how it relates to the impacts 
for which the projects are designed to mitigate. Most published assessments of restoration effectiveness have been conducted on small $1^{\text {st }}$ to $3^{\text {rd }}$ order streams and are designed around short-term studies with little or no pre-restoration data; and consequently, many of these studies have produced highly equivocal results (Klein et al. 2001, Roni et al. 2002, and Palmer et al. 2005). For example, Marttila et al. (2015) examined the effectiveness of 27 restored stream reaches over 10-years post construction. They found that the restored streams were similar to the near-pristine reference sites and restoration was responsible for significant positive changes in stream habitat (Marttila et al. 2015). In contrast, Violin et al. 2011 found that restored reaches were indistinguishable from degraded reaches with respect to habitat (pebble counts and streambed complexity based on depth).

There are several reasons why assessments of stream restoration effectiveness may produce ambiguous results. First, most restoration projects focus on physical structure of the stream channel. However, it may be that many restoration projects are incapable of producing benefits to streams due to broad constraints on the landscape, such as continuous influxes of sediment, dispersal barriers, or poor water quality (McClurg et al. 2007, Poplar-Jeffers et al. 2009, Petty and Merriam 2012). Second, most restoration projects are conducted over relatively small spatial scales (e.g., over a distance of several hundred meters), and there is emerging evidence that many processes in streams are driven by watershed or "riverscape" (sensu Fausch et al. 2002) scale processes (Hitt and Angermeier 2011). Consequently, localized improvements to stream habitat may be incapable of offsetting watershed scale impacts (Lepori et al. 
2005, McClurg et al. 2007). Finally, most studies designed to assess restoration effectiveness are flawed in some way or another (Klein et al. 2001). The majority of stream restoration projects are not monitored (Palmer et al. 2007), and those that are monitored typically lack pre-restoration data. Long term study designs that combine pre- and post- restoration data and contrast restoration sites with reference sites (i.e., Before-After paired Control-Impact designs, $\mathrm{BACl}$ ) are needed to reach unequivocal conclusions regarding restoration effectiveness (Roni et al. 2002). Unfortunately, longterm, $\mathrm{BACl}$ designed studies are rare, and particularly so in larger river systems (Stewart et al. 2009).

Nowhere is the need to understand the benefits and potential limitations of stream restoration greater than in the coal mining region of the central Appalachian Mountains, USA. Large-scale surface mining (aka Mountaintop Removal Mining - Valley Fill (MTRVF)) in the central Appalachians is responsible for the destruction of greater than 3200 $\mathrm{km}$ of headwater streams (USEPA 2005), with most of these impacts occurring in southern West Virginia (WV) and eastern Kentucky (KY) (Petty et al. 2013). MTR-VF results in the complete rearrangement of headwater catchments and it has been shown that on-site reclamation of mined areas provides minimal benefits (Fritz et al. 2010, Petty et al. 2013, Jaegar 2015). Consequently, off-site (outside of permitted mine boundaries) mitigation often is required to offset the impacts from mining, and oftentimes mitigation is in the form of stream channel restoration in larger systems downstream. To give a sense of the scale of this activity, we know of at least 68 
restoration projects that were constructed in the MTR-VF region of WV between 2006 and 2011; some of which are installed on large rivers $\left(>1000 \mathrm{~km}^{2}\right)$.

Despite recent advances in our understanding of large river ecology, studies of restoration effectiveness in large rivers $\left(>1000 \mathrm{~km}^{2}\right)$ are quite rare. For example, natural changes in channel morphology on large rivers over time have been studied for many years; however, not with respect to restoration (Wyżga 2012, Ziliani and Surian 2012). Several recent studies of the effects of flow restoration on fish and macroinvertebrate assemblages in the Rhone River have added greatly to our understanding of the potential for human facilitated improvements to large river ecosystems (Lamouroux and Olivier 2015, Dolédec et al. 2015, and Daufresne et al. 2015). However, to our knowledge, there have been no published studies of the benefits of stream channel reconstruction for physical habitat improvement on a large river system. This is an important knowledge gap given that stream channel restoration projects are increasingly common on larger rivers as an offset to impacts to smaller streams.

There have been few systematic studies of mitigation effectiveness in the central Appalachian coalfields, and our understanding of mitigation effectiveness on larger rivers lags worldwide. Consequently, we conducted a BACl designed study of mitigation effectiveness on the Little Coal River in south-central WV. The lower Little Coal River is a part of the Coal River watershed, which has been a highly altered area 
through MTR-VF. The goals of the Little Coal River restoration project were to: 1facilitate the downstream transport of fine sediments, thus exposing cobble and gravel substrate; 2- increase streambed complexity and fish cover; and 3-increase fish and macroinvertebrate biodiversity. The objective of our research was to determine the status of the first two goals and determine the stability of any changes. Having five years of data (four years of post-construction) allowed us to identify immediate responses, delayed responses, and the persistence of physical habitat changes due to restoration.

\section{Study Area and Design}

The Little Coal River watershed drains approximately $994 \mathrm{~km}^{2}$ of mountainous terrain in Lincoln, Boone, and Kanawha Counties in WV, and the Little Coal River main stem is approximately $56 \mathrm{~km}$ in length (Figure 1). Although mining has occurred in the watershed for more than a century, several large mountaintop mines are currently active with a total of more than 1780 hectares of valley fills (Merriam et al. 2013). Currently, the Little Coal River has relatively low productivity, caused by excess sulfates and poor habitat quality (Bodkin et al. 2007). The river is also listed on the United States Environmental Protection Agencies 303(d) list for fecal coliform contamination. Approximately $12 \%$ of the Coal River Watershed has previously been mined or is currently being mined. The area is naturally sandy, with multiple sand quarries located on the river. Historically, the river was used to barge sand, coal, and timber over 14 locks and dams during the turn of the $19^{\text {th }}$ century. The river is steep banked and forested; originally called the Walhondecepe which translates to "big ditch" or "ditch place". 
The specific focus of this study was the lower $15 \mathrm{~km}$ of the Little Coal River main stem (Figure 1). The BACl study area was delineated into three segments: 1- an upper segment where $3 \mathrm{~J}$-hook and 12 cross vane structures were constructed in early 2000 prior to beginning of this study; 2- a lower segment where 20 cross vane structures were installed in the summer of 2010 (Plate 1); and 3- a middle segment, which served as a control, where no structures were constructed. Our study began in 2009 and construction of the lower reach structures was completed in late June 2010. Each of the segments contained a representative reach that was at least 40 times the mean stream width (Freund and Petty 2007; Merovich and Petty 2007). The three segments started and ended at the head of a riffle. The length of the representative upper, middle, and lower reaches were $915 \mathrm{~m}, 1278 \mathrm{~m}$, and $1433 \mathrm{~m}$, respectively and the upper and lower reach each contained three cross-vane structures. These sub-reaches were used for finer scale analysis of substrate type and detailed longitudinal profile of the stream channel. Although, the middle reach was located between our treatment sites, we believe there was sufficient distance $(\sim 2 \mathrm{~km})$ between reaches to be independent of structure influences.

\section{Methods}

\section{Thalweg Profile}

A thalweg profile is a method for obtaining in-stream measurements of habitat complexity (Petty et al. 2001, Merriam et al. 2011) and was conducted over the entire $15 \mathrm{~km}$ of the study area in 2009-2013. Sampling stations were spaced every $1 / 2$ mean stream width longitudinally along the thalweg (i.e., area of maximum flow). 
Measurements were taken using a three meter copper pole was used. At each sampling station, the following information was collected: channel unit type (e.g., pool, riffle sensu Petty et al. 2001), water depth, and distance to nearest fish cover (DFC) (Petty et al. 2001, Merriam et al. 2011). Fish cover was any object large enough to conceal a $20 \mathrm{~cm}$ fish. The copper pole was marked every $10 \mathrm{~cm}$ for depth measurements and the pole was used horizontally to estimate DFC. Every fifth thalweg point was entered into a gps so that consistency was maintained from year to year. Approximately $400(+/-10)$ thalweg points were taken every year.

\section{Substrate Composition and Water Depth}

One of the primary objectives of the habitat enhancing structures was to facilitate transport of sand and silt through constriction of channel flow. In order to assess the effectiveness of the structures in exposing cobble and gravel substrate, sediment composition was measured over the entire $15 \mathrm{~km}$ study area. Two teams of two people started on opposite sides of the river, with two people collecting measurements and the other two recording. Five measurements by each team were taken as they walked at a $45^{\circ}$ angle from bank to bank. The teams recorded sediment type and water depth $( \pm 1 \mathrm{~cm})$ measurements at evenly spaced points along that transect. The sediment types were: silt $(<1 \mathrm{~mm})$, sand $(1-2 \mathrm{~mm})$, gravel $(2-64 \mathrm{~mm})$, cobble $(64-256 \mathrm{~mm})$, and boulder (>256 mm). Sampling points were at the left bank, middle left, center, middle right, and right bank. Every fifth right bank location was entered into a gps to assist in consistency from year to year. Approximately 3000 points were recorded by each team each year. 
Finer scale sediment and water depth measurements were also collected in the $40 x$ MSW representative upper, middle and lower reaches. These measurements allowed us to quantify localized details that may not be observed on coarser scale measurements. Three people walked the river recording a measurement every 3-4 m. Each person sampled a section of the river, either the left bank, center, or right bank. Within each $1 / 3$ of the river, the individuals synchronously moved to obtain a representative sample spanning the width of their section. Water depth and sediment type measurements were taken at each location. Within each reach, each person sampled $\sim 300$ points each year. These data produced a finer scale assessment of substrate change within representative reaches.

\section{Cross-Sectional Channel and Longitudinal Profile Geometry}

Cross-section surveys and longitudinal profile surveys were conducted in the summer of 2009 (prior to in-stream structure constructions in the lower segment) and summers of 2010-2013 (following in-stream structure construction in the lower segment) to provide information on channel geometry and change over time within the three study segments of the Little Coal River (Roni et al 2005). A cross-sectional survey examines the streambed and banks, in a single location, perpendicular to the stream. The surveys quantified changes in wetted channel complexity, bankfull channel, and floodplain widths and depths over time (Harrelson et al. 1994). All cross sections and longitudinal profiles were benchmarked with $80 \mathrm{~d}$-galvanized nails into large trees to maintain stations over time. Channel surveys were conducted using a Spectra LL300 automaticleveling rotary laser level and receiver (Trimble Navigation Limited, Sunnyvale, CA.). 
Forty five $\mathrm{cm}$ rebar stakes were placed into the terraces and bank at bankfull height and flagged so the study can be duplicated at the exact locations in future years.

Within the middle reach a cross-section survey was conducted within a representative pool and a representative riffle. In the lower section three cross-sections were conducted at each location of a proposed structure. These were taken at $30 \mathrm{~m}$ upstream, at the proposed root-wad location, and $30 \mathrm{~m}$ downstream. We decided on a wide range in case the structures were not placed exactly where we were told. All cross-section surveys were conducted from terrace to terrace. A bankfull measurement and edge of water measurement were taken on both sides of the river. The cross sections were conducted pre- and post-construction so morphological changes due to the habitat enhancement structures could be quantified. Lastly, 10 cross sections were performed at two structures in the upper reach (30 and $15 \mathrm{~m}$ upstream, at the root wad, and 15 and $30 \mathrm{~m}$ downstream).

Using the Spectra LL300 automatic-leveling rotary laser level and receiver longitudinal profiles were taken within each of the three study segments (Sweeny et al. 2004). A longitudinal profile measures the streambed within the thalweg for a given distance (Harrelson et al. 1994). The longitudinal profiles were conducted from the head of a riffle to the head of a riffle along the thalweg within each of our representative reaches. At each point within the profile a bed elevation and a bankfull elevation was taken approximately every $300 \mathrm{~m}$. Longitudinal profiles were monumented with $45 \mathrm{~cm}$ rebar to ensure starting and ending points were consistent. A measurement was taken every 
elevation change felt by the surveyor. If bedform was relatively homogeneous, a point was taken every eight meters. Approximately 200 elevation points were taken within each reach each year.

\section{Statistical Analysis}

The central purpose of our analysis was to test the hypothesis that structures (i.e., Jhooks and cross vanes) had a significant positive effect on substrate composition, streambed complexity, and fish habitat quality and that these effects persisted over time. All analyses were performed in the program R ( $R$ Development Core Team 2008), and a significance level of 0.1 was used in hypothesis testing. An alpha level of 0.1 was used because of the variable nature of the aquatic systems and low sample size (Bryant et al. 2004, Al-Chokhachy et al. 2010, Miller et al. 2010).

We used repeated measures ANOVA to test for significant differences for distance to fish cover, total depth, pool depth, pool length, and distance to pool. We used contingency table analysis to test for significant changes in substrate composition between 2009 (pre-construction baseline) and each subsequent year. Paired t-tests were also performed on cross sectional data. Our variables for cross sections were area, perimeter, coefficient of variation (CV) of depth, entrenchment ratio, and perimeter:area ratio. Pairwise comparisons were made between years as well as compared back to 2009 (pre-construction year). In each representative reach, stream bed perimeter lengths were calculated from the longitudinal profiles in ArcGIS. The data was imported as $\mathrm{X}-\mathrm{Y}$ coordinates and the measuring tool was used to trace the profile 
for its entire length. Complexity ratios were calculated using the length of each longitudinal profile; 2009 was set as a ratio of 1 (for each reach) and each subsequent year's ratio was calculated by comparing it to the perimeter in 2009. Perimeters were also compared directly to the previous year in order to quantify year-over-year changes in complexity. There was some measurement error associated with this because surveys varied $+/-15 \%$ each year. Additionally, we used paired t-tests on longitudinal survey data to test for significant differences in channel geometry between the 2009 and every other year. We used the deviation of each bed measurement from a monumented point as our variable.

\section{Results}

We observed a consistent significant effect of NCD structure construction on distance to fish cover (DFC). DFC initially decreased by approximately $50 \%$ in the lower reach, increased $20 \%$ in the middle reach, and remained constant in the upper reach in 2010 as compared to the previous year (Figure 2). There was a significant year effect, reach effect and reach $x$ year interaction in DFC (Table1). Within the lower reach, DFC remained significantly shorter every year post-construction compared to 2009 (Figure 2). In the upper reach DFC was highly variable from 2011 to 2013 compared to 2009 and 2010. DFC was also highly variable within the middle reach from year to year (Figure 2). The lower reach did become deeper and closer to fish cover throughout the years, whereas the middle reach remained less variable (Figure 3). Total water depth was found to be statistically different $(p>0.001)$ in each reach and each year, becoming deeper in the lower reach post-construction and shallower in the upper reach over time. 
Similarly, pool length was statistically different $(p>0.001)$ with respect to reach; and distance to pool had a reach $\mathrm{x}$ year effect; however, pool depth was only different with respect to reach (Table 1).

NCD structure construction had no significant effect on substrate composition over the entire $15 \mathrm{~km}$ of river (Figure 4). Contingency table analysis revealed a significant difference in substrate within the upper representative reach when comparing 2009 to $2012(p=0.029)$, whereas comparisons between other years were not significantly different. Substrate composition in the middle reach changed significantly from baseline in $2011(p=0.083)$ and $2013(p=0.086)$. All changes in substrate were associated with a decrease in sand and an increase in gravel/cobble substrate. Interestingly, the only significant difference detected in the lower reach was comparing preconstruction to $2011(p=0.006)$. Based on our fine sediment measurements the localized effects of the structures are $5 \mathrm{~m}$ above and $5 \mathrm{~m}$ below. The structures are typically $30 \mathrm{~m}$ in length; therefore $\sim 40 \mathrm{~m}$ of cobble/gravel substrate is exposed due to structures.

We found no statistical difference between baseline cross-sectional profiles and subsequent years at any reach with respect to area, perimeter, cv of depth, entrenchment ratio, and perimeter area ratio (Figure 5). Furthermore, longitudinal profiles in the upper and middle reaches did not differ statistically over time (Table 2). In contrast, we observed substantial changes in the longitudinal profile geometry of the lower reach when comparing pre- and post-construction conditions (Figure 6). Within 
the lower reach, the longitudinal channel geometry from 2009 was significantly different ( $p>0.001)$ from every year post-construction. Furthermore, longitudinal measures of bed complexity showed measurable changes that were not observed statistically. For example, the upper reach experienced decreased complexity over time, but appears to be approaching an equilibrium (Table 2, Figure 5). The middle reach has remained relatively constant. The lower reach increased in complexity by $80 \%$ immediately after construction (comparing 2009 to 2010) but appears to be approaching an equilibrium at approximately $50 \%$ increased complexity from pre-construction (Table 2).

\section{Discussion}

Our BACl study design allowed us to quantify measurable changes to the Little Coal River channel produced by construction of the NCD structures. Measuring how structures changed morphology immediately post-construction, as well as long term, allows us to detect shifts in complexity and provides a better understanding of the stability and equilibrium that this dynamic system reaches following manipulation. Based on the visual and statistical results, the middle reach was highly stable over time. Therefore we can conclude that any changes in the lower reach were most likely caused by NCD structure construction.

We observed measurable positive benefits of structure construction on physical habitat conditions in the lower Little Coal River. NCD structure construction significantly increased the availability of pools from a distance of over $400 \mathrm{~m}$ to less than $200 \mathrm{~m}$ and deep habitats increased by $50 \%$. Also DFC decreased from $>50 \mathrm{~m}$ to $<30 \mathrm{~m}$ and pool 
length increased by $>20 \%$. These variables increased due to structure construction and appear to be stable over time (Figure 2). These findings add to a growing list of studies that have demonstrated positive effects of stream channel restoration on physical habitat conditions (Whiteway et al. 2010). A literature search of restoration projects revealed that all of the 51 reports investigated had a positive change on pool size and depth due to mitigation activities (Whiteway et al. 2010). The depth of the reaches as well as streambed complexity did have a positive shift; however, they seem to be very unstable at this time. Visually comparing the longitudinal profiles for the lower section to the other sections, one can see how variable the lower section is compared to the more stable upper and middle reaches. Lepori et al. (2005) showed an increase of eight times in streambed heterogeneity in the restored versus unrestored reaches, also other projects have had a significantly higher heterogeneity in flow and depth (Pretty et al. 2003).

Within the lower reach improvements were observed in the immediate vicinity of the structures; however, our sampling program averaged results over the entire reach and was unable to distinguish a statistically significant structure effect. We did detect localized shifts from sand dominated substrates to substrates dominated by cobble and gravel within the $40 \mathrm{~m}$ area of the structures. We suggest using this information for future project spacing. The structures may have an additive effect and placing them closer together would remove sand from a larger area and potential increase those $5 \mathrm{~m}$ buffer. Another possible reason is that the structures are overwhelmed by the amount of sand in the system. The river banks are predominantly sand and other activities 
(mining and development) in the watershed may lead to increases of sand inputs.

Discharge data was obtained from a gaging station $\sim 20 \mathrm{~km}$ downstream and included the Big Coal River; in July of 2009, 2010, and 2011 discharge averaged $\sim 400 \mathrm{ft}^{3} / \mathrm{s}$, in July 2012 had an average discharge of $\sim 200 \mathrm{ft}^{3} / \mathrm{s}$. This lack of rain may be the cause of the elevated sand substrate that was detected in every reach. Therefore flow may be a large part of the effectiveness of NCD structures. Although the relationship between sand and discharge is complicated, an increase in flow often transports more sediment (Iseya and Ikeda 1987).

While there was minimal statistical difference in longitudinal profiles between years, we believe this approach should be implemented more in the literature because it allows one to visualize changes over time. There is a significant lack in the literature for stream longitudinal profiles in any capacity (Roni 2005). An increase with these methods would allow researchers, managers, and practitioners to pinpoint areas with large/small changes. Additionally, this approach could help in the construction phase, to allow for the adjustment of structure creation for higher benefits because all streams act differently (Hilderbrand et al. 2005). Because of the length of our longitudinal profiles we overlooked any small changes in streambed complexity. We were able to detect some large scale changes, but could have benefited from a smaller finer scale longitudinal profile around structures. 
Despite benefits to habitat structure, our results suggest an initial increase and then a decrease in complexity when the river becomes more stable, 3-4 years postconstruction. The lower reach has a $57 \%$ increase in streambed complexity after 4 years, which is down from $80 \%$ the year after construction. Although this complexity has decreased it does seem to be stabilizing around $55 \%$. This finding is consistent with previous studies and emphasizes the need for long term monitoring of NCD structure benefits in this system. Levell and Chang (2008) observed that the mean particle size in the restored reach decreased after many years and lead to aggradation. Additionally, Champoux et al. (2003) found that a restoration project in the 1960s increased in pool area from $267 \mathrm{~m}^{2}$ to $625 \mathrm{~m}^{2}$ after restoration, but has since decreased to $488 \mathrm{~m}^{2}$ whereas reaching equilibrium.

Due to our study design we were able to compare pre-construction site with postconstruction, but also compare an unrestored reach, and an older restored reach. We found that areas with structures were far more dynamic than the unrestored, middle reach. The middle reach showed little change in metrics over time. The complexity remained about the same $( \pm 6 \%)$ over the five year study period. The upper reach, which contained older structures, varied greatly in complexity over the study period $( \pm 27 \%)$. The lower reach also had high variability with respect to complexity $( \pm 80 \%)$. Clearly, these structures add a level of complexity to the river and cause the river to become more dynamic and variable from year to year. We would have expected the lower reach to become more like the upper reach as time progressed and that was observed in the complexity ratio comparisons of the previous year. However, it does 
appear that the upper reach structures are becoming shallower over time. Depth is lower in the upper reach than the middle and lower reach. The lower reach may follow this same pattern and may begin to fail and aggregate over time. This leads us to believe that these structures may need a maintenance plan associated with them. Aggregation could cause the structures to fill completely, however with proper maintenance and possible dredging these structures could maintain their physical benefits into the future. Monitoring of the Little Coal River is suggested to determine if restored sites are reaching a dynamic equilibrium or continuously aggregating. 


\section{Literature Cited}

Al-Chokhachy, R., B.B. Roper, and E.K. Archer. 2010. Evaluating the status and trends of physical stream habitat in headwater streams within the interior Columbia River and upper Missouri River basins using an index approach. Transactions of the American Fisheries Society. 139(4): 1041-1059.

Bash, J. S. and C. M. Ryan. 2002. Stream restoration and enhancement projects: is anyone monitoring?. Environmental management, 29(6):877-885.

Bodkin, R., J. Kern, P. McClellan, A. Butt, and C. Martion. 2007. Limiting total dissolved solids to protect aquatic life. Journal of Soil and Water Conservation 62(3): 57A-61A.

Bronner, C. E., A. M. Bartlett, S. L. Whiteway, D. C. Lambert, S.J. Bennett, and A.J. Rabideau. 2013. An assessment of US stream compensatory mitigation policy: necessary changes to protect ecosystem functions and services. JAWRA Journal of the American Water Resources Association, 49(2), 449-462.

Brown, K. 2000. Urban stream restoration practices: an initial assessment. The Center for Watershed Protection. Elliot City, MD.

Bryant, M.D.,J.P. Caouette, and B.E. Wright. 2004. Evaluating stream habitat survey data and statistical power using an example from southeast Alaska. North American Journal of Fisheries Management. 24: 1353- 1362.

Champoux, O., P.M. Biron, and A.G. Roy. 2003. The Long-Term Effectiveness of Fish Habitat Restoration Practices: Lawrence Creek, Wisconsin. Annals of the Association of American Geographers 93: 42-54.

Daufresne, M., J. Veslot, H. Capra, G. Carrel, A. Poirel, J.M. Olivier, and N. Lamouroux . 2015. Fish community dynamics (1985-2010) in multiple reaches of a large river subjected to flow restoration and other environmental changes. Freshwater Biology. 60(6):1176-1191.

Dolédec, S., M. Forcellini, J.M. Olivier, and N. Roset. 2015. Effects of large river restoration on currently used bioindicators and alternative metrics. Freshwater Biology. 60(6):1221-1236

Entrekin, S.A., T.J. Hoellein, G.A. Lamberti, J.L. Tank, and E.J. Rosi-Marshall.2008. Responses in organic matter accumulation and processing to an experimental wood addition in three headwater streams. Freshwater Biology 53:1642-1657. 
Fausch, K. D., Torgersen, C. E., Baxter, C. V., and H.W. Li. 2002. Landscapes to riverscapes: bridging the gap between research and conservation of stream fishes. BioScience, 52(6): 483-498.

Fraley, L. M., Miller, A. J., and C. Welty. 2009. Contribution of In-Channel Processes to Sediment Yield of an Urbanizing Watershed1. Journal of the American Water Resources Association, 45(3): 748-766.

Freund, J. G. and J. T. Petty. 2007. Response of fish and macroinvertebrate bioassessment indices to water chemistry in a mined Appalachian watershed. Environmental Management 39:707-720.

Fritz, K. M., S. Fulton, B. R. Johnson, C. C. Barton, J. D. Jack, D. A. Word, and R. A. Burke. 2010. Structural and functional characteristics of natural and constructed channels draining a reclaimed mountaintop removal and valley fill coal mine. J. N. Am. Benthol. Soc. 29:673-689.

Harrelson, C. C., C.L. Rawlins, and J.P. Potyondy. 1994. Stream channel reference sites: an illustrated guide to field technique. U.S. Forest Service, Rocky Mountain Forest and Range Experiment Station, General Technical Report RM-245, Fort Collins, Colorado

Hilderbrand, R. H., A.C. Watts, and A.M. Randle. 2005.The myths of restoration ecology. Ecology and Society.10(1):19.

Hitt, N. P., and P.L. Angermeier. 2011. Fish community and bioassessment responses to stream network position. JNABS Journal, 30(1): 296-309.

Iseya, F., and H. Ikeda. 1987. Pulsations in bedload transport rates induced by a longitudinal sediment sorting: A flume study using sand and gravel mixtures. Geografiska Annaler. Series A. Physical Geography, 15-27.

Jaeger, K. L. 2015. Reach-scale geomorphic differences between headwater streams draining mountaintop mined and unmined catchments. Geomorphology, 236:25-33.

Jansson, R., H. Backx, A.J. Boulton, M. Dixon, D. Dudgeon, F. Hughes, K. Nakamura, E. Stanley, and K. Tockner. (2005) Stating mechanisms and refining criteria for ecologically successful river restoration: a comment on Palmer et al.(2005). Journal of Applied Ecology 42:218-222.

Klein, L. R., S.R. Clayton, J.R. Alldredge, and P. Goodwin. 2007. Long-Term Monitoring and Evaluation of the Lower Red River Meadow Restoration Project, Idaho, USA. Restoration Ecology 15(2):223-239. 
Koebel, J. W. 1995. An historical perspective on the Kissimmee River restoration project. Restoration ecology, 3(3):149-159.

Lamouroux, N., and J.M. Olivier. 2015. Testing predictions of changes in fish abundance and community structure after flow restoration in four reaches of a large river (French Rhône). Freshwater Biology. 60(6):1118-1130.

Lepori, F., D. Palm, E. Brannas, and B. Malmqvist. 2005. Does restoration of structural heterogeneity in streams enhance fish and macroinvertebrate diversity? Ecological Applications 15: 2060-2071.

Levell, A.P. and H. Chang. 2008. Monitoring the channel process of a stream restoration project in an urbanizing watershed: a case study of Kelley Creek, Oregon, USA. River Research and Applications 24:169-182.

Marttila, M., P. Louhi, A. Huusko, A. Mäki-Petäys, T. Yrjänä, and T. Muotka. 2015. Long-term performance of in-stream restoration measures in boreal streams. Ecohydrology.

McClurg, S. E., J. T. Petty, P. M. Mazik, and J. L. Clayton. 2007. Stream ecosystem response to limestone treatment in acid impacted watersheds of the Allegheny Plateau. Ecological Applications 17(4):1087-1104.

Merovich, G.T. and J.T. Petty. 2010. Continuous response of benthic macroinvertebrate assemblages to a discrete disturbance gradient: consequences for diagnosing stressors. Journal of North American Benthological Society 29(4):12411257.

Merovich, G. T. and J. T. Petty. 2007. Interactive effects of multiple stressors and restoration priorities in a mined Appalachian watershed. Hydrobiologia 575:13-31.

Merriam, E.R., J.T. Petty,G.T. Merovich, J.B. Fulton, and M.P. Strager.2011. Additive effects of mining and residential development on stream conditions in central Appalachian watershed. Journal of the North American Benthological Society 30(2):399-418.

Miller, S. W., P. Budy, and J.C. Schmidt. 2010. Quantifying Macroinvertebrate Responses to In-Stream Habitat Restoration: Applications of Meta-Analysis to River Restoration. Restoration Ecology 18:8-19.

Miller, A. C., R. H. King, and J. E. Glover. 1983. Design of a gravel bar habitat for the Tombigbee River near Columbus, Mississippi. Miscellaneous Paper EL-83-1. US Army Engineer Waterways Experiment Station, Vicksburg, MS. 
Minter, M. 2009. Thesis. Organic matter processing and opportunities for stream mitigation in anintensively mined West Virginia watershed. West Virginia University.

Moerke, A.H., K.J. Gerard, J.A. Latimore, R.A. Hellenthal and G.A. Lamberti. 2004. Restoration of an Indiana, USA, stream: bridging the gap between basic and applied lotic ecology. Journal of the North American Benthological Society 23(3):647-660.

Palmer, M., J.D. Allan, Meyer, J., and E.S. Bernhardt. 2007. River restoration in the twenty-first century: data and experiential knowledge to inform future efforts.

Restoration Ecology, 15(3):472-481.

Palmer, M.A., E.S. Bernhardt, J.D. Allan et al. 2005. Standards for ecologically successful river restoration. The Journal of Applied Ecology 42:208-217.

Palmer, M. A., K.L. Hondula, and B.J. Koch. 2014. Ecological Restoration of Streams and Rivers: Shifting Strategies and Shifting Goals. Annual Review of Ecology, Evolution, and Systematics, 45:247-269.

Palmer, M.A., H.L. Menninger, and E.S. Bernhardt. 2009. River restoration, habitat heterogeneity and biodiversity: a failure of theory or practice? Freshwater Biology 55(1): 205-222.

Petty, J. T., J. Freund, P. Lamothe, and P. Mazik. 2001. Quantifying instream habitat in the upper Shavers Fork basin at multiple spatial scales. Proceedings of the Annual Conference of the Southeastern Association of Fish and Wildlife Agencies 55:81-94.

Petty, J. T., G. Gingerich, J.T. Anderson, and P.F. Ziemkiewicz. 2013. Ecological function of constructed perennial stream channels on reclaimed surface coal mines. Hydrobiologia, 720(1):39-53.

Petty, J. T., J. B. Fulton, M. Strager, G. T. Merovich, J. Stiles, and P. Ziemkiewicz. 2010. Landscape indicators and thresholds of stream ecological impairment in an intensively mined Appalachian watershed. Journal of the North American Benthological Society 29:1292-1309.

Petty, J. T., and G. D. Grossman. 2004. Restricted movement by mottled sculpin (Pisces: Cottidae) in a southern Appalachian stream. Freshwater Biology 49:631-645

Petty J. T., P.J Lamothe, and P. M. Mazik. 2005. Spatial and seasonal dynamics of brook trout populations inhabiting a central Appalachian watershed. Transactions of the American Fisheries Society. 134:572-587. 
R Development Core Team.2008.: R Foundation for Statistical Computing; R: a language and environment for statistical computing. Vienna, Austria .Available at http://www.R-project.org.

Roni, P., T. J. Beechie, R. E. Bilby, F. E. Leonetti, M. M. Pollock, and G. R. Pess. 2002. A review of stream restoration techniques and a hierarchical strategy for prioritizing restoration in Pacific Northwest watersheds. North American Journal of Fisheries Management 22:1-20.

Rosgen, David. 2006.Cross-vane, W-weir, and J-hook vane structure: Description, design and application for stream stabilization and river restoration. Wildland Hydrology, Inc. Ft. Collins, Colorado.

Roni, P. and E. Quimby. 2005. Monitoring stream and watershed restoration. CABI.

Schiemer, F., C. Baumgartner, and K. Tockner.1999. Restoration of floodplain rivers: The'Danube restoration project'. Regulated Rivers: Research \& Management, 15(1), 231-244.

Sweeney, B. W., T.L. Bott, J.K. Jackson, L.A. Kaplan, J.D. Newbold, L.J. Standley., ... and R.J Horwitz. 2004. Riparian deforestation, stream narrowing, and loss of stream ecosystem services. Proceedings of the National Academy of Sciences of the United States of America, 101(39):14132-14137.

Simon, A., M. Doyle. M. Kondolf, F.D. Shields Jr., B. Rhoads, and M. McPhillips, 2007. Critical Evaluation of How the Rosgen Classification and Associated "Natural Channel Design" Methods Fail to Integrate and Quantify Fluvial Processes and Channel Response. Journal of the American Water Resources Association 43(5):1117-1131.

Stewart ,G.B., H.R. Baliss, D.A. Showler, W.J. Sutherland and A.S. Pullen.2009. Effectiveness of engineered instream structure mitigation measures to increase salmonid abundance: a systematic review. Ecological Applications 19:931-941.

Tockner, K., F. Schiemer, C. Baumgartner, G. Kum, E. Weigand, I. Zweimüller, ... and J.B. Layzer. 1999. The Danube restoration project: species diversity patterns across connectivity gradients in the floodplain system. Regulated Rivers: Research \& Management, 15(1), 245-258.

U.S. Environmental Protection Agency. 2005. Mountaintop Mining/Valley Fills in Appalachia: Final Programmatic Environmental Impact Statement. Accessed December 20, 2007. 
U.S. Environmental Protection Agency. A Field-Based Aquatic Life Benchmark for Electrical conductivity in Central Appalachian Streams (2010) (External Review Draft). U.S. Environmental Protection Agency, Washington, DC, EPA/600/R-10/023A, 2010.

Violin, C. R., P. Cada, E.B. Sudduth, B.A. Hassett, D.L. Penrose, and E.S. Bernhardt. 2011. Effects of urbanization and urban stream restoration on the physical and biological structure of stream ecosystems. Ecological Applications, 21(6):19321949.

Whiteway, S. L., P. M. Biron, A. Zimmermann, O. Venter, and J. W. A. Grant. 2010. Do instream restoration structures enhance salmonid abundance? A metaanalysis. Canadian Journal of Fisheries and Aquatic Sciences 67:831-841.

Wyżga, B., J. Zawiejska, A. Radecki-Pawlik, and H. Hajdukiewicz. 2012. Environmental change, hydromorphological reference conditions and the restoration of Polish Carpathian rivers. Earth Surface Processes and Landforms, 37(11), 1213-1226.

Ziliani, L., and N. Surian. 2012. Evolutionary trajectory of channel morphology and controlling factors in a large gravel-bed river. Geomorphology, 173, 104-117. 


\section{Tables and Figures}

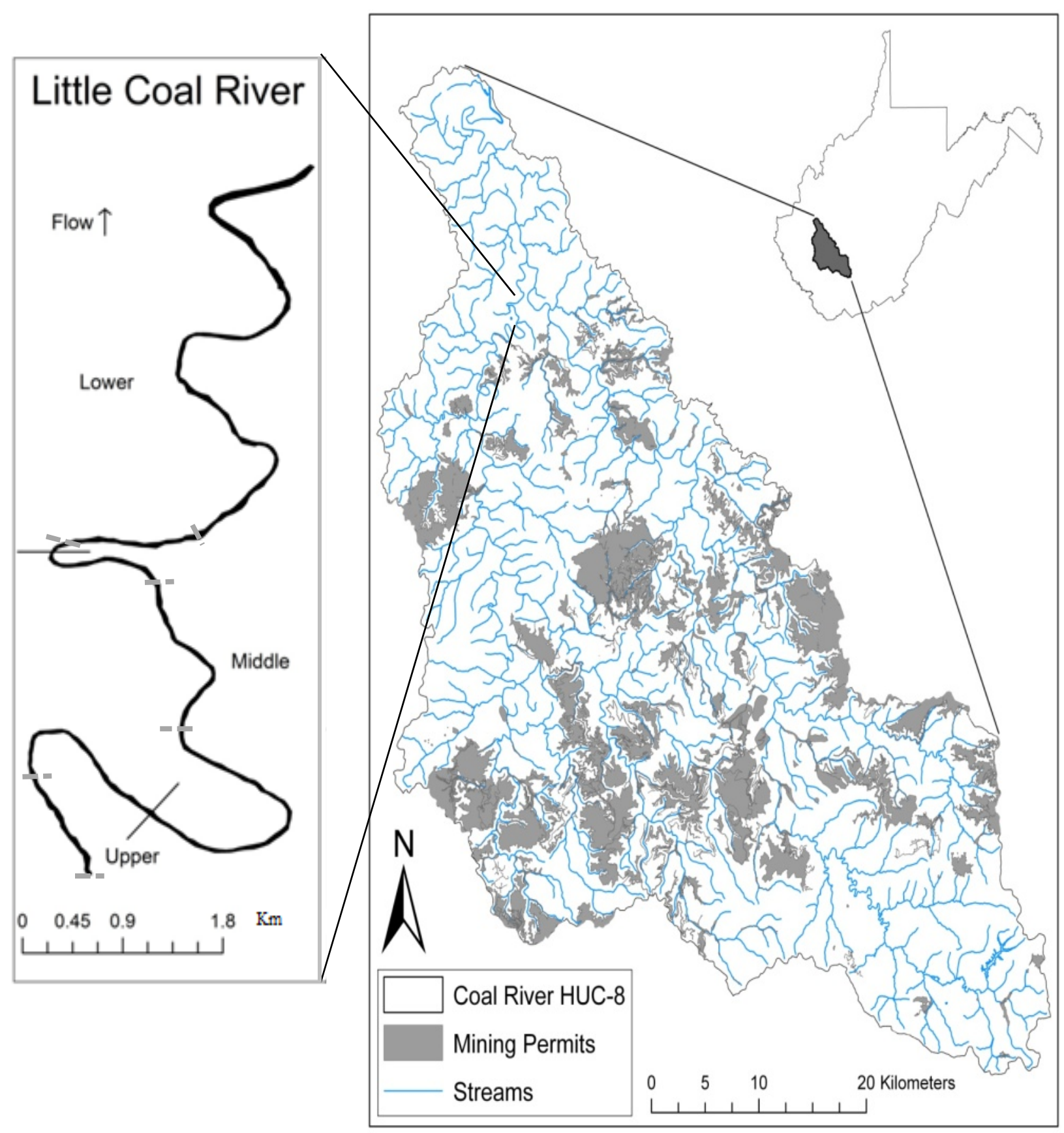

Figure 1. Map of study area with upper, middle, and lower study segments delineated. The dashed gray lines are the beginning and end of each representative reach. Structures in the upper reach were constructed in $\sim 2005$. Structures in the lower reach were constructed in 2010. 


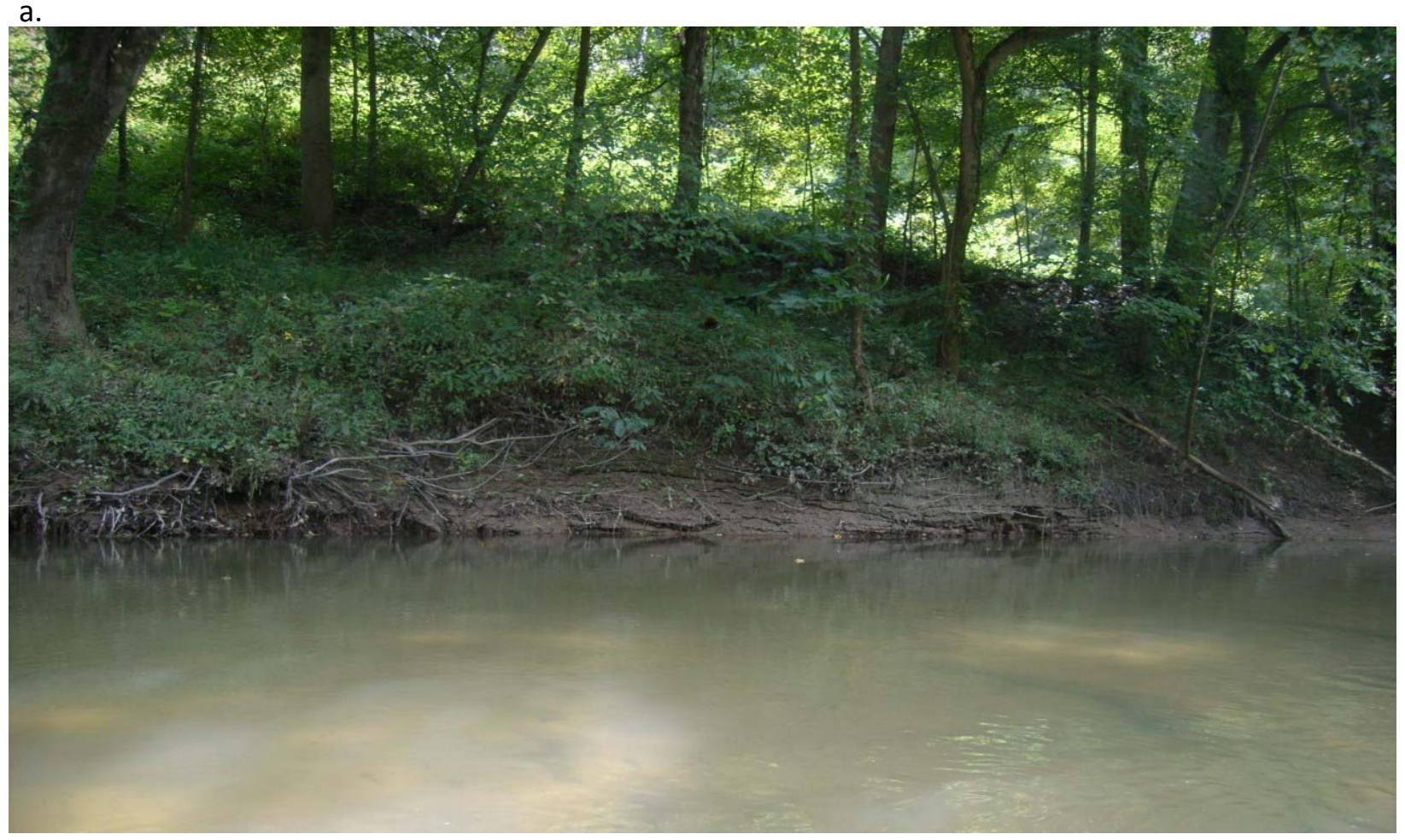

b.

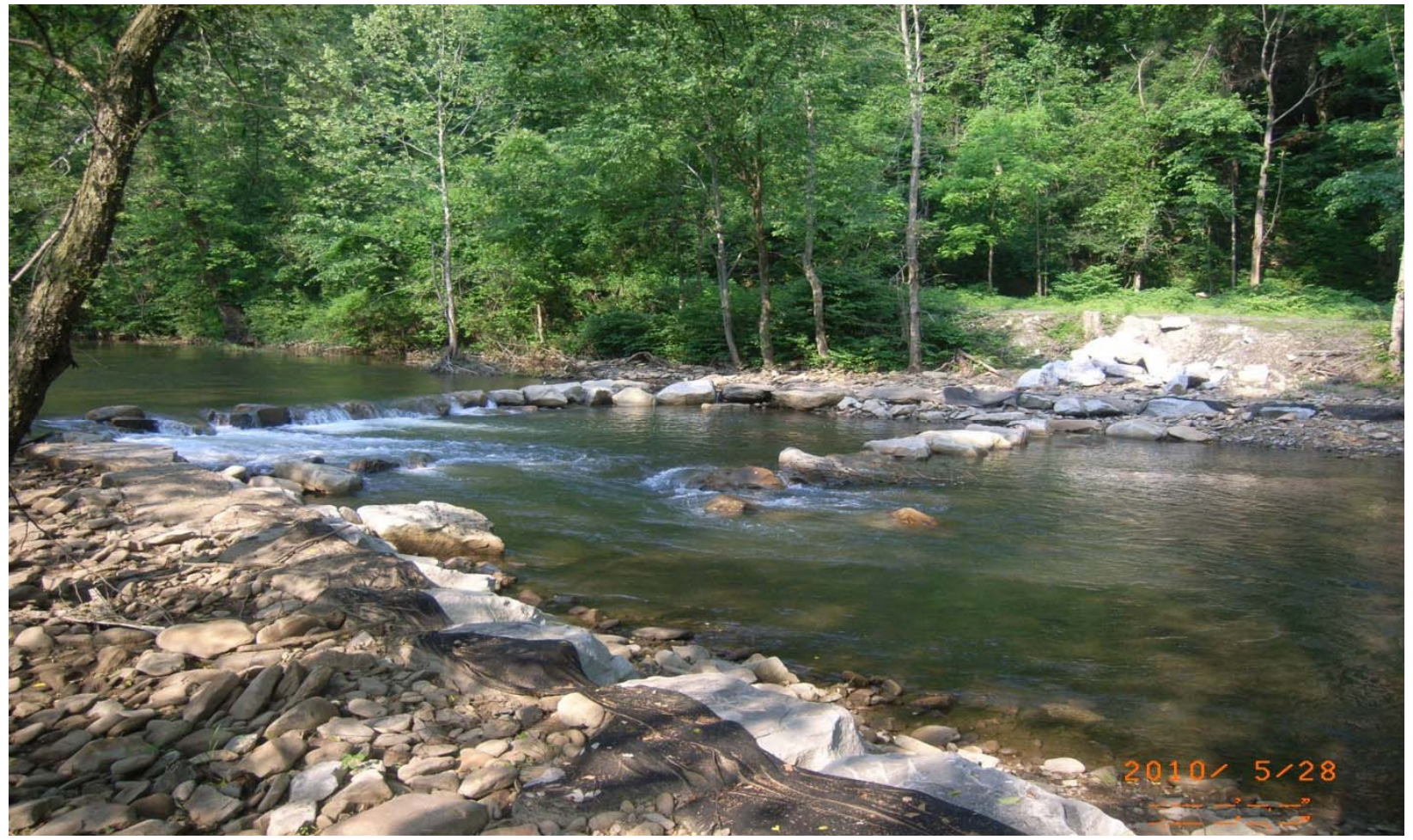

Plate 1. (a.)Pre- and (b.)Post-const ruction photo of a structure in the lower reach. 

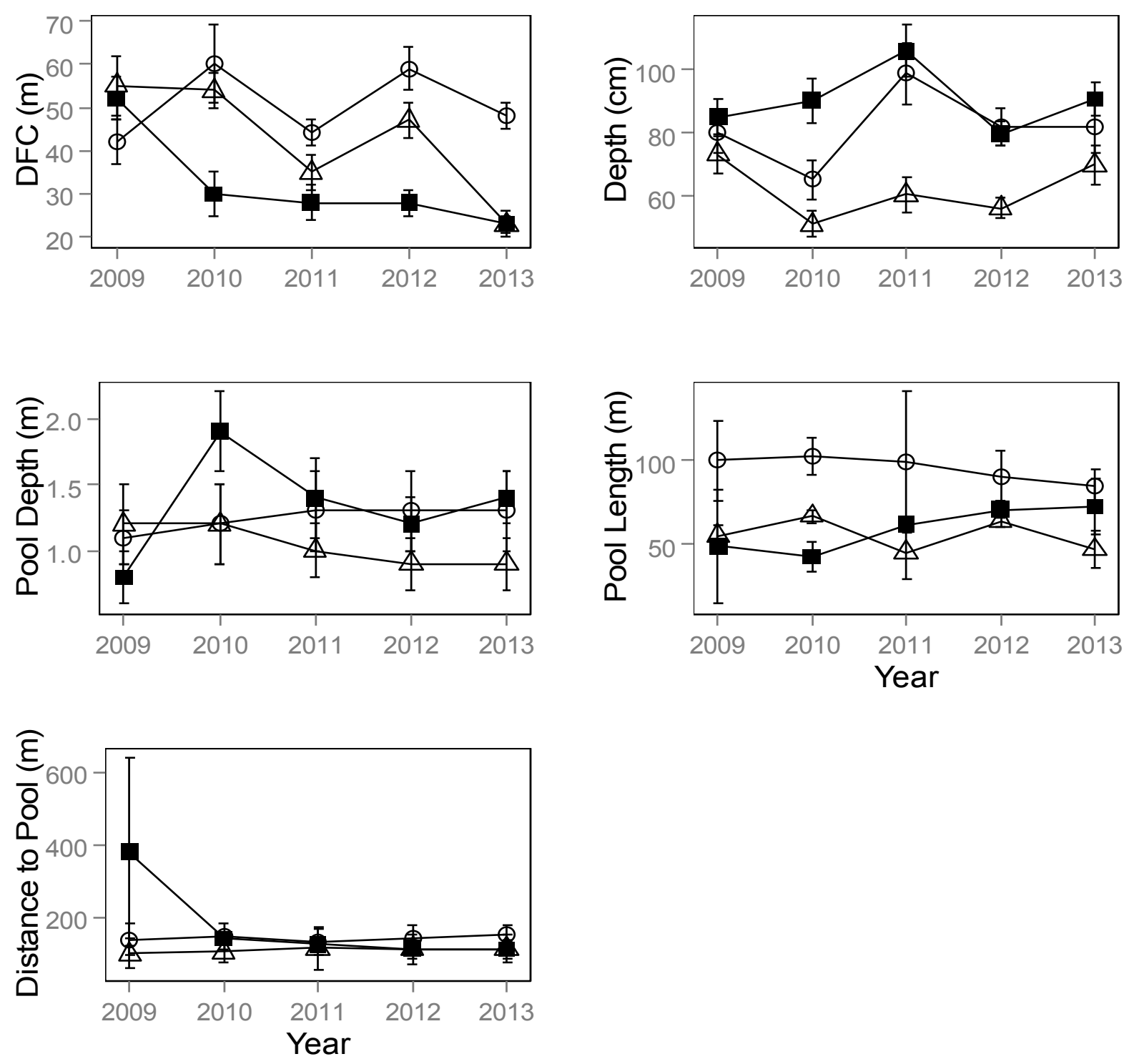

Figure 2. Morphological attributes (Means and SE) with respect to year and reach; the dark square are the lower reach (2009 is pre-construction), open triangles are the upper reach, and open circle are the middle reach. DFC=distance to fish cover. 
Table 1. ANOVA results of morphological parameters; distance to fish cover (DFC), total depth, pool depth, pool length, and distance to pool with respect to year and reach. Significant values are bolded.

\begin{tabular}{llccccc}
\hline Parameter & Variable & Df & Sum Sq & Mean Sq & F-Value & P-Value \\
\hline DFC & Reach & 2 & 7355 & 3677 & 3.294 & $\mathbf{0 . 0 3 7}$ \\
& Year & 4 & 102278 & 25570 & 22.906 & $<\mathbf{0 . 0 0 1}$ \\
& Reach:Year & 8 & 56270 & 7034 & 6.301 & $<\mathbf{0 . 0 0 1}$ \\
& Residuals & 672 & 750126 & 1116 & & \\
Total Depth & Reach & 2 & 110915 & 55458 & 32.248 & $<\mathbf{0 . 0 0 1}$ \\
& Year & 4 & 41135 & 10284 & 5.98 & $<\mathbf{0 . 0 0 1}$ \\
& Reach:Year & 8 & 28134 & 3517 & 2.045 & $<\mathbf{0 . 0 0 1}$ \\
Pool Depth & Residuals & 672 & $1.00 \mathrm{E}+06$ & 1720 & & \\
& Reach & 2 & 312.18 & 156.09 & 32.775 & $<\mathbf{0 . 0 0 1}$ \\
& Year & 4 & 26.66 & 6.67 & 1.399 & 0.246 \\
& Reach:Year & 8 & 14.37 & 1.8 & 0.377 & 0.928 \\
Pool Length & Residuals & 56 & 266.7 & 4.76 & & \\
& Reach & 2 & 295193 & 147596 & 10.677 & $<\mathbf{0 . 0 0 1}$ \\
& Year & 4 & 14434 & 3609 & 0.261 & 0.901 \\
& Reach:Year & 8 & 75851 & 9481 & 0.686 & 0.702 \\
Distance to pool & Residuals & 56 & 774111 & 13823 & & \\
& Reach & 2 & 101986 & 50993 & 0.575 & 0.566 \\
& Year & 4 & 134748 & 33687 & 0.38 & 0.822 \\
& Reach:Year & 8 & $2.00 \mathrm{E}+06$ & 187739 & 2.115 & $\mathbf{0 . 0 4 9}$ \\
& Residuals & 56 & $5.00 \mathrm{E}+06$ & 88753 & & \\
\hline
\end{tabular}




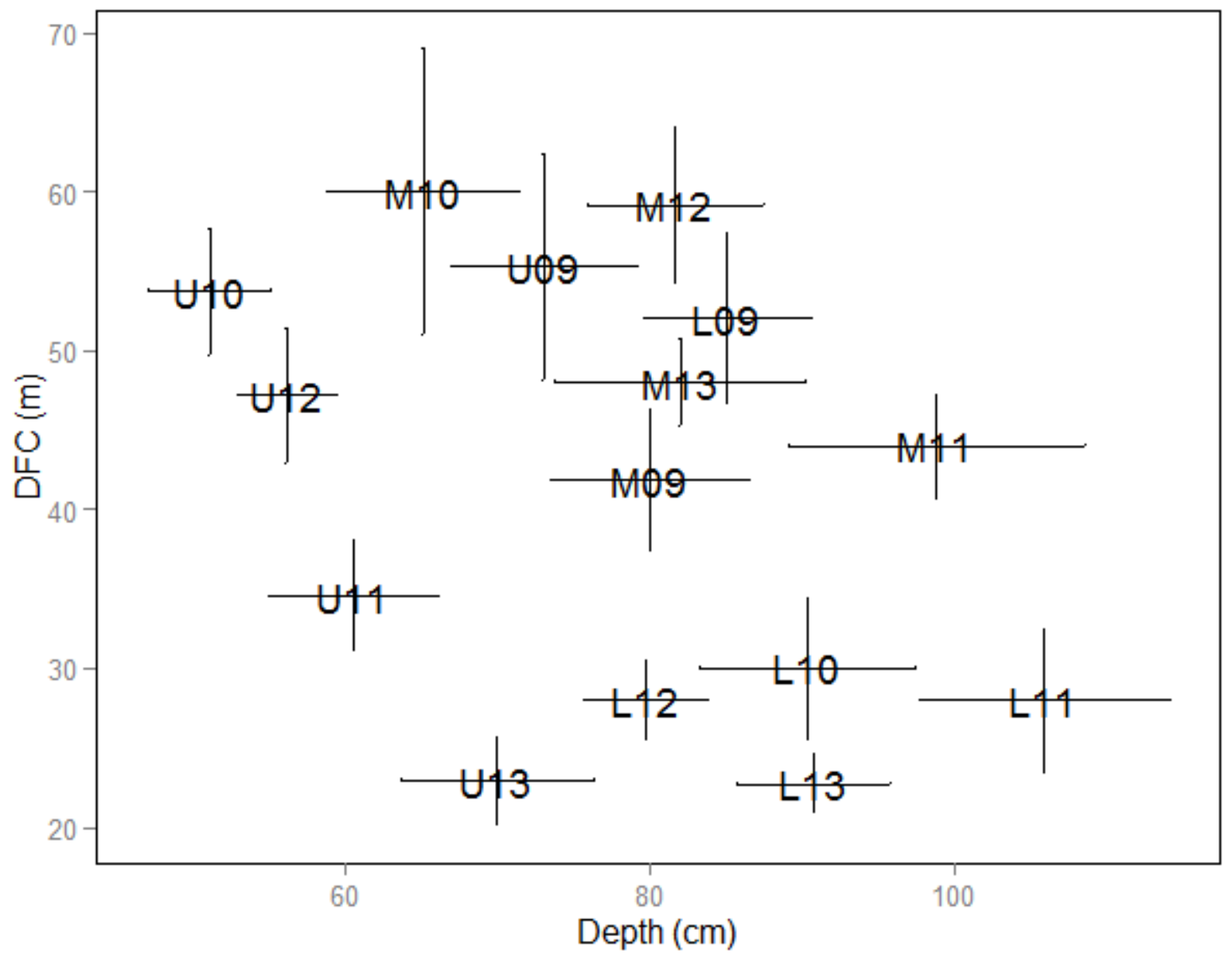

Figure 3. Mean (SE) distance to fish cover (DFC) with respect to depth. U=upper reach, $M=$ middle reach, and $L=l o w e r$ reach, the number represents the year. 

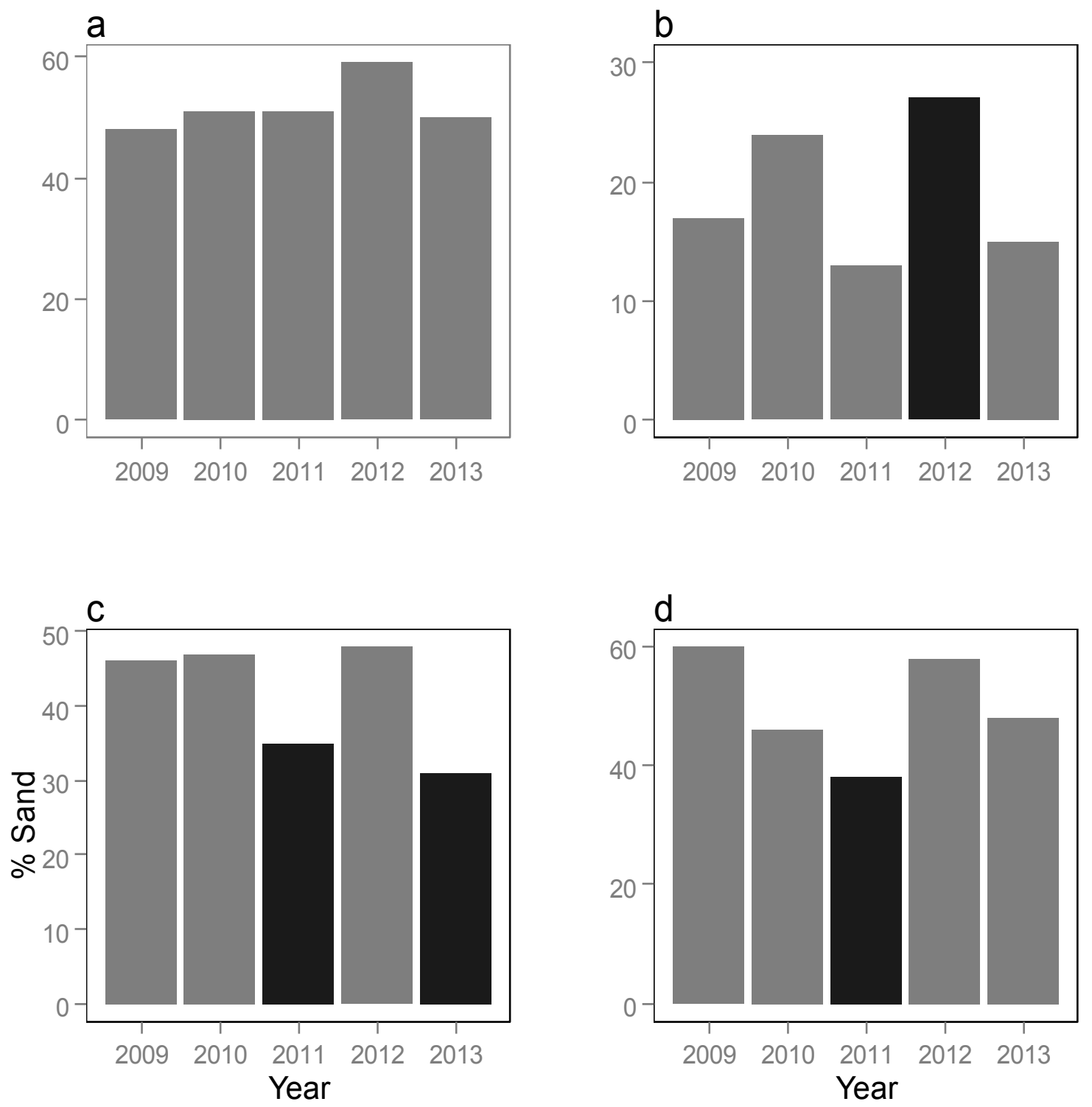

Figure 4. Percent of sand substrate by year and reach. Black bars represent significant difference between that year and 2009 (pre-construction) within that reach. a=entire river, $b=$ upper reach, $c=$ middle reach, and $d=l o w e r$ reach. 
a
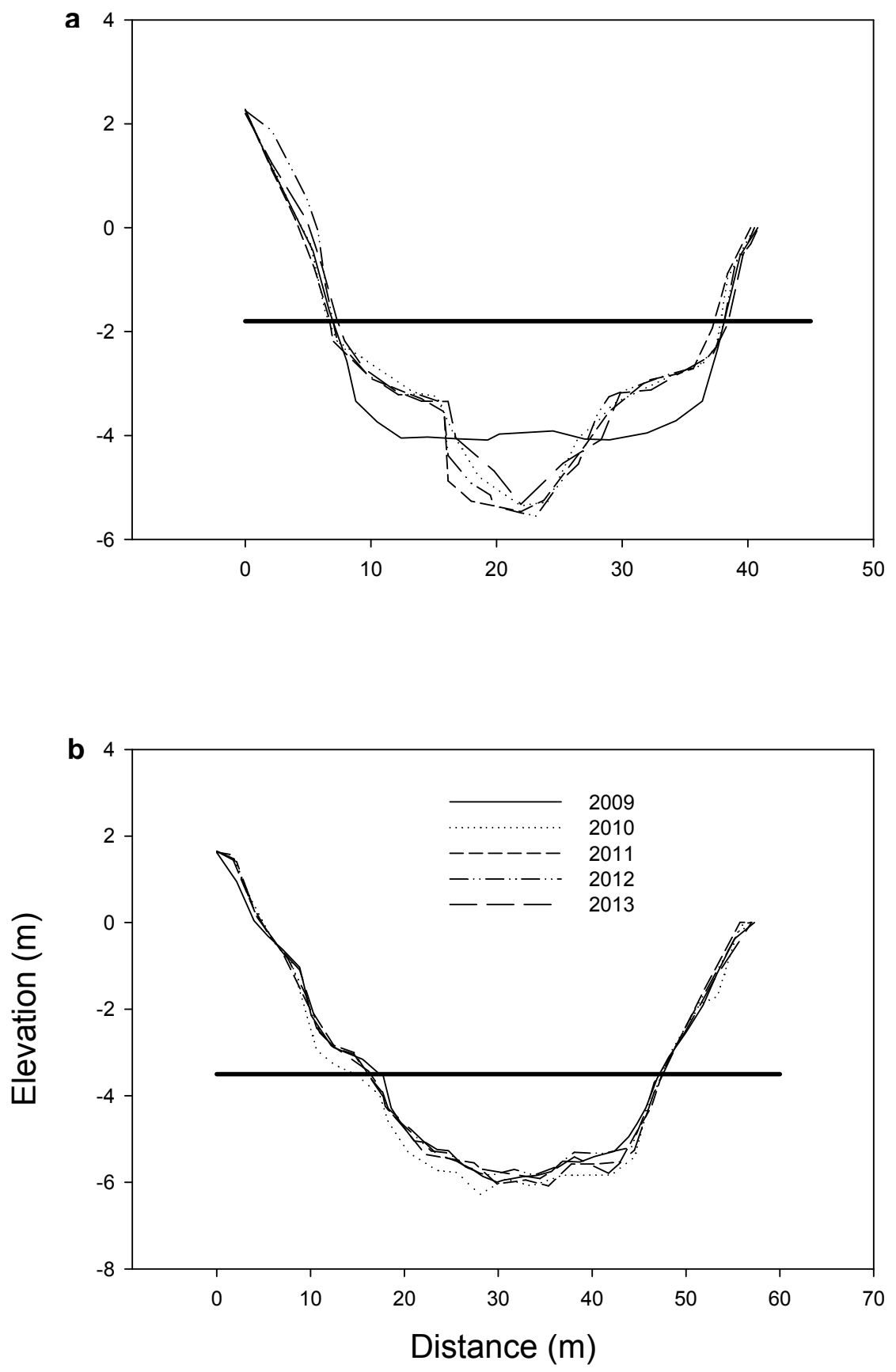

Figure 5. Cross sectional profiles (a) is pre-and post-construction in the lower reach at rootwad and (b) is upper reach $15 \mathrm{~m}$ upstream of structure. Bold line represents bankfull height. 
a.
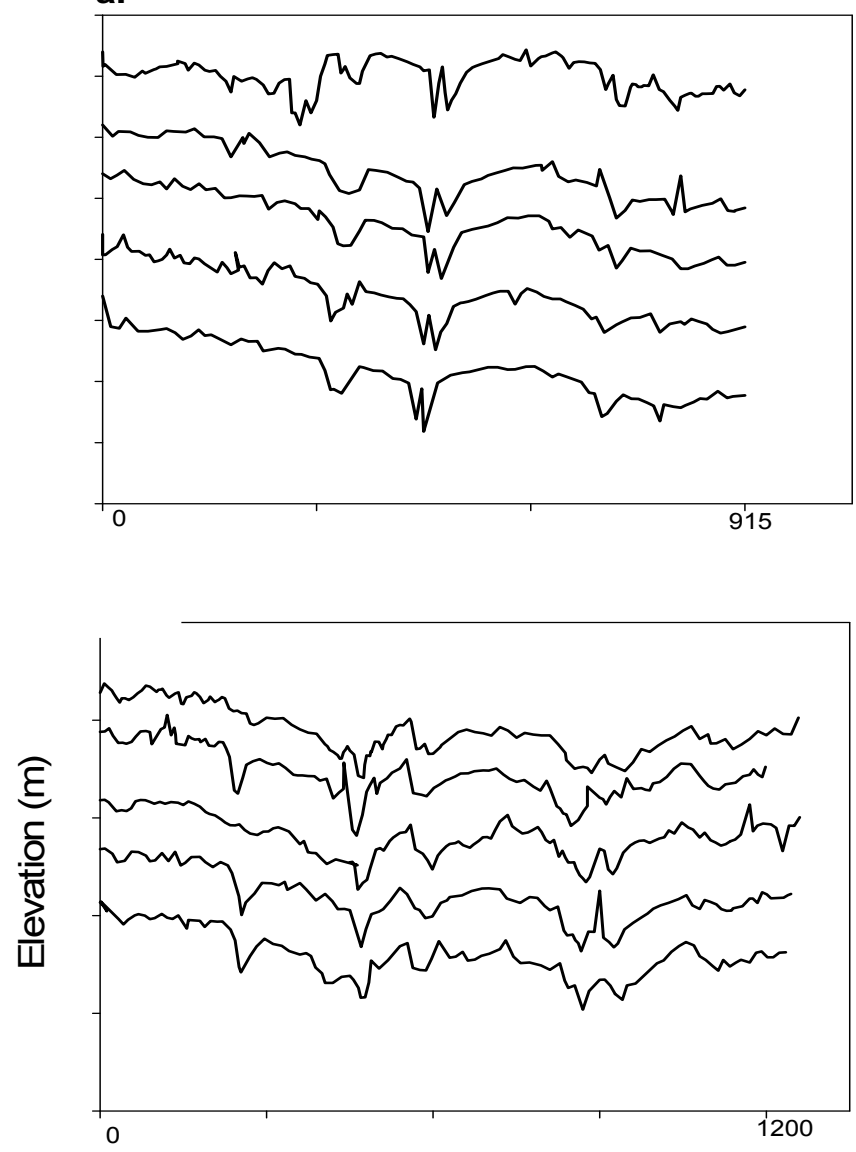

c.

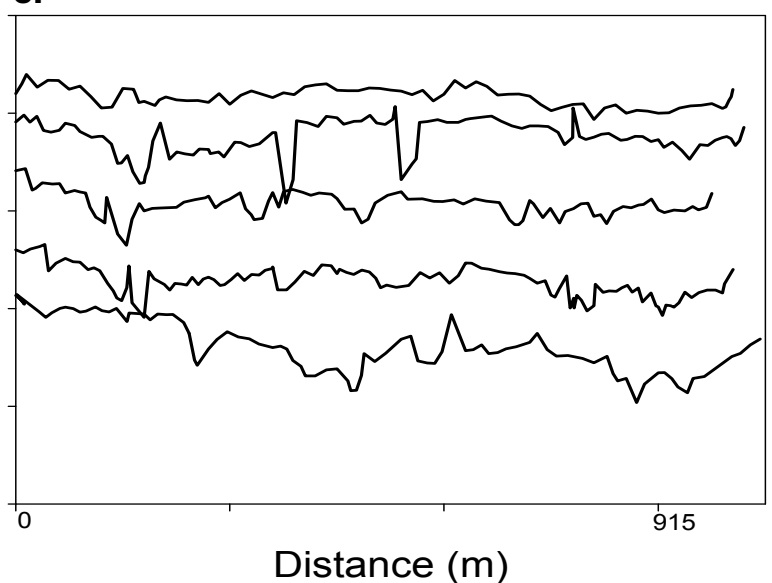

3 Figure 6. Longitudinal profiles in chronological order from top to bottom (2009-2013).

4 Profiles are separated so difference can be visualized; all points were multiplied by 5 to

5 exaggerate elevation changes. $a=$ upper reach, $b=$ middle reach, and $c=l o w e r$ reach. 
CHAPTER 2: STREAM RESTORATION IN A LARGE, INTENSIVELY MINED APPALACHIAN RIVER: MACROINVERTEBRATE AND FISH ASSEMBLAGE RESPONSE

Eric Miller* and J. Todd Petty

School of Natural Resources, West Virginia University, Morgantown, WV 26506

*Corresponding Author: Emiller9@mix.wvu.edu 


\section{Abstract}

Natural channel designed (NCD) structures have been the industry standard for stream restoration projects for decades and are used for reducing erosion, maintaining channel profile, and increasing habitat complexity and aquatic biodiversity. The Little Coal River is a large $\left(1000 \mathrm{~km}^{2}\right)$ river in Southern West Virginia that has been the subject of over 10 years of mitigation effort and millions of dollars of NCD structure construction. Using a before-after-control-impact study design with preconstruction data we investigated changes in the fish and macroinvertebrate assemblages associated with NCD structures. We observed significant, localized macroinvertebrate response to restoration that was mediated by shifts from sand dominated substrates to cobble and gravel. However, overall improvements to invertebrate assemblages at the river reach scale were not observed, because restoration did not affect substrate composition at the larger scale. In contrast, we did observe reach scale effects of restoration on fish assemblages. However, the overall response was difficult to interpret as being ecologically beneficial or not. Total fish biomass, total abundance, and catostomidae (sucker) abundance increased in response to NCD structure construction. Fish species richness and integrity measures remained unchanged, and gamefish abundance decreased, which may be due to fishing pressure. No new species were seen in restored reaches; our results suggest that large suckers are moving into newly developed pools. Benthic macroinvertebrate and fish assemblages may change and continue to improve over time as the negative impacts from NCD construction lessen. However, long-term ecological benefits of physical restoration actions on large Appalachian rivers response to restoration will likely remain equivocal until actions are 
taken to improve water quality (electrical conductivity $\sim 1000 \mu \mathrm{s} / \mathrm{cm}$ ), which appears to constrain fish and invertebrate response to restoration in this region.

Key words: NCD structures, Little Coal River, Mountain-top removal and valley fill mining, West Virginia Coalfields 


\section{Introduction}

Throughout the world anthropogenic activities negatively impact aquatic ecosystems, and to potentially offset these impacts stream mitigation programs are implemented (Kauffman et al. 1997). Although the practice of stream mitigation has been occurring for nearly 100 years in the United States, the science of understanding restoration is much younger (Palmer et al. 2007). Furthering our knowledge about stream mitigation projects assists practitioners, decision makers, scientists, and the public in understanding the benefits and short comings of stream mitigation. Due to the infancy of the science there are still information gaps in the literature. One clear gap is the biological response to in-stream structures in large rivers.

In-stream structures began in the 1930s by the Civilian Conservation Corps in order to enhance fish stocks; the practice remained virtually unchanged until the 1980s (Thompson and Stull 2002). Although many of the designs from the 1930s are still in use today, there is a higher level of science and engineering incorporated. Natural Channel Design (NCD) based structures (cross-vanes, W-weirs, J-hooks) are extremely popular today and seem to be showing no signs of slowing installation (Miller and Kochel 2009). The primary goals of NCD structures are to maintain grade control, maintain a stable width/depth ratio, limit erosion, and create a stable channel (Rosgen 2001). An additional goal for NCD structures is improving habitat through increasing streambed and flow complexity (Miller and Kochel 2009), which in turn would affect biological communities. The practice of NCD is to enhance or repair damaged systems by using reference streams as blueprints (Rosgen 1998). 
It is unrealistic to think that historic conditions can be re-created through stream mitigation. The fundamental goal of stream restoration is not the immediate re-creation of a system but to provide a sound foundation for natural processes to build upon (Palmer et al. 2007). To understand if natural processes are being "jumpstarted", long term studies have to be used. It's unknown how long it takes or if it's even possible for a system to return to a historic reference state. Furthermore, each separate project likely will have a different response, depending on the unique context of the aquatic system (Hilderbrand et al. 2005). Projects range from riparian zone planting, adding meanders to a stream, reconnecting the floodplain, moving a stream to an original location, or the addition of in-stream structures for bank stabilization and habitat enhancement. Because projects range greatly in application, it should be no surprise that results are highly variable, especially biologically. Our study attempts to fill some of the knowledge gap concerning fish and macroinvertebrate response, by using a six year dataset on a large $\left(1000 \mathrm{~km}^{2}\right)$ Appalachian river.

Evidence of fish and macroinvertebrate response to the installation of NCD structures on small streams, although equivocal, is reasonably well documented (Muotka et al. 2002, Lepori et al. 2005, Baldigo et al. 2010, and Miller et al. 2010). However, similar investigations on larger rivers $\left(>1000 \mathrm{~km}^{2}\right)$ are extremely rare. One very good recent example is a large restoration project on the Rhone River, France (Daufresne et al. 2015, Dolédec et al. 2015, and Lamouroux and Olivier 2015). The sites range from $15,000-50,000 \mathrm{~km}^{2}$ and are part of a power plant flow restoration project (Lamouroux, 
and Olivier 2015). These studies have found that macroinvertebrates are variable and unpredictable. However, fish communities demonstrate measurable response in restored reaches (Daufresne et al. 2015, Dolédec et al. 2015, and Lamouroux and Olivier 2015). There has also been some work installing artificial riffles in a large river with positive results (Miller et al. 1983). However the effects of in-stream structures on large rivers are unknown as well as the effects these structures have in the central Appalachia region where there is a broad need for restoration action (Merovich et al. 2013, Petty et al. 2013).

The coal rich area of Southern West Virginia is highly concentrated with stream mitigation projects. However little is known about the effects of these projects on the ecological functions of the streams. The state of West Virginia requires stream mitigation as an offset to the impacts of mountain top/valley fill mining. There have been over 100 projects in the last ten years in five counties alone (unpublished data from West Virginia Department of Environmental Protection). As an off-site (removed from mine company boundaries) mitigation project the West Virginia Department of Environmental Protection has installed mitigation structures on over $8 \mathrm{~km}$ of river on the Little Coal River at a cost exceeding $\$ 3 \mathrm{M}$. The goals of the Little Coal River restoration project were to: 1- facilitate the downstream transport of fine sediments, thus exposing cobble and gravel substrate; 2- increase streambed complexity and fish cover; and 3increase fish and macroinvertebrate biodiversity. Although prevalent in small streams, there is a clear need in the literature for understanding the fish and macroinvertebrate response to a NCD structures in large rivers; using a $\mathrm{BACl}$ design and a six year 
dataset we can help fill knowledge gaps by investigating the goal of increasing fish and macroinvertebrate biodiversity.

\section{Study Area}

The Little Coal River watershed drains approximately $994 \mathrm{~km}^{2}$ of mountainous terrain in Lincoln, Boone, and Kanawha Counties in West Virginia, and the Little Coal River main stem is approximately $56 \mathrm{~km}$ in length (Figure 1). Although mining has occurred in the watershed for more than a century, several large mountaintop mines are currently active with a total of more than 1780 hectares of valley fills (Merriam et al. 2013). Currently, the Little Coal River has relatively low productivity, caused by excess sulfates and poor habitat quality (Bodkin et al. 2007). The river is also listed on the United States Environmental Protection Agencies 303(d) list for fecal coliform contamination. Approximately $12 \%$ of the Coal River watershed has previously been mined or is currently being mined. The area is naturally sandy, with multiple sand quarries located on the river. Historically, the river was used to barge sand, coal, and timber over 14 locks and dams during the turn of the $19^{\text {th }}$ century. The river is steep banked and forested; originally called the Walhondecepe which translates to "big ditch" or "ditch place".

The specific focus of this study was the lower $15 \mathrm{~km}$ of the Little Coal River main stem (Figure 1). The BACl study area was delineated into three segments: 1- an upper segment where three J-hook and 12 cross vane structures were constructed in early 2000s prior to beginning of this study; 2- a lower segment where 20 cross vane 
structures were installed in the summer of 2010; and 3- a middle segment, which served as a control, where no structures were constructed. Although, the middle reach was located between our treatment sites, we believe there was sufficient distance $(\sim 2 \mathrm{~km})$ between reaches to be independent of structure influences.

\section{Field Methods}

Fish Assemblages

Our study began in May 2009; construction of the lower reach structures began in August 2009 and was completed in late June 2010. Within each reach we sampled fish using a modified electrofishing boat from the WVDEP. The modified boat was built by Jason Morgan and Ryan Pack; it incorporated a platform mounted to a white water raft. This allowed the boat to handle faster waters when necessary but still be maneuverable in less than one foot of water. The boat was equipped with a 15 h.p. outboard motor and a Smith and Root generator system. Within each study reach, five 92m (300ft) sections were sampled in mid-August of 2009 and 2014. In the upper section five instream structures were randomly selected and sampled. In the middle reach five randomly selected section were sampled they were; two glides, a riffle, a pool, and a

run. Working close with the WVDEP and Appalachian Stream Restoration (practitioners) in the lower reach, five areas prior to structure construction (2009) were sampled and then again every year for five years after construction. Per WVDEP protocol we used 500 seconds as our target shock time, with the concentration being on the structures themselves and the expert judgment of the WVDEP. Species type, total 
length, and weight were recorded for each fish. Fish sampling was conducted in the exact same locations for the entirety of the study.

\section{Benthic Macroinvertebrate Assemblages and Water Quality}

Benthic macroinvertebrates have been used as bioindicators in many studies (Rosenburg and Resh 1993). We sampled benthic macroinvertebrates in our three reaches in the spring and fall of 2009-2014. In each reach a total of 9 benthic samples were collected from two different types of habitat: sand-silt and cobble-gravel. A total of 27 samples per substrate type per season (Spring and Fall) were collected. Over the course of the study 540 benthic macroinvertebrates samples were collected. We sampled each substrate type using a kick net with a 500 um mesh and dimensions of $335 \times 508 \mathrm{~mm}$. Within each area a $0.25 \mathrm{~m}^{2}$ region of stream bed was disturbed to ensure that the majority of the macroinvertebrates were collected. Nine samples were collected from each habitat type within each reach; each sample was comprised of four "kicks". A kick consisted of placing the net beneath a riffle and vigorously disturbing the substrate. After the completion of four kick samples from one habitat type, the contents of the kick net were preserved in $95 \%$ ethanol. The net was thoroughly cleaned and then the next habitat type was sampled using the same protocol. Substrate mapping was also conducted in each reach to determine percentages of sand and will be referred to; however, see Chapter 1 for protocol and extended results. While collecting fish and macroinvertebrates at each site field water quality measurements were collected using a multi-parameter YSI 650 unit fitted with a 600XL snode (Yellow 
Springs Instruments, Yellow Springs, OH, USA). The YSI measured temperature $\left({ }^{\circ} \mathrm{C}\right)$, $\mathrm{pH}$, specific electrical conductivity $(\mu \mathrm{s} / \mathrm{cm})$, dissolved oxygen $(\mathrm{mg} / \mathrm{L})$ and total dissolved solids (g/L). Water quality measurements were recorded within every reach, during ever visit.

\section{Laboratory methods}

\section{Benthic Macroinvertebrates}

WVDEP (2009) protocol was used for macroinvertebrate laboratory methods. The benthic macroinvertebrate samples were rinsed in a $500 \mu \mathrm{m}$ sieve and then placed into a custom gridded sorting tray. The sorting tray is $12.7 \mathrm{~cm}$ ( 5 in) by $50.8 \mathrm{~cm}$ (20 in) and divided into 100 equal square centimeters. Random numbers are then drawn and that sample is collected $2.5 \mathrm{~cm}^{2}\left(1 \mathrm{in}^{2}\right)$ at a time. To ensure proper extraction of the square inch a custom square inch "cookie cutter" is placed straight down to the selected number. The sample is extracted and placed into a petri dish. Macroinvertebrates are counted and samples are pulled until 160-240 inverts are collected. Benthic macroinvertebrates are then identified to the genus or the lowest possible level using Peckarsky et al. (1990) and Merritt and Cummins (2008). Identified macroinvertebrates were then entered into the West Virginia stream condition index (WVSCl) calculator which is West Virginia's family level IBI (Gerritsen et al. 2000).

\section{Statistical Analysis}

All analysis was done in Program $\mathrm{R}$ in the base package and vegan package ( $\mathrm{R}$ Core Team 2014). Important metrics for using macroinvertebrates are often centered on 
ephemeroptera, plecoptera, and trichoptera, (EPT). For the state of West Virginia the index of biotic integrity for macroinvertebrates is the West Virginia Stream Condition Index (WVSCl). WVSCI uses a subsample of 200 individuals and many parameters to calculate a final score (Gerritsen et al. 2000). The WVSCl uses the following metrics, \%EPT, \% dominant individuals, \% mayflies, \%stoneflies, EPT abundance, and EPT family richness. The final result of the WVSCI is an index number that ranges from $0-$ 100 (Gerritsen et al. 2000). The final WVSCI score placed into a stream condition category of excellent (>85.0), good (85.0-70.0) marginal (69.9-55.0), and poor $(<55.0)$. We used a series of one way ANOVA's with our factors being reach, season, year, and substrate and our response variables being; abundance, WVSCI score, \%EPT and EPT richness.

For all fish analysis the five sites within each reach, each year were combined. Since increasing biodiversity is a goal of these structures, one of the metrics we used to determine success was the Shannon-Wiener diversity index. Diversity scores combines' information on species richness and evenness to better understand species composition (Magurran 1996). In addition to diversity index we used traditional fish metrics to help determine fish assemblage change due to structures. We used a repeated measures ANOVA to test for significant changes in; diversity, species richness total biomass, total abundance, gamefish abundance, average fish biomass, sucker abundance, and cyprinid abundance. Because these structures are designed to create pools, we decided to use sucker and cyprinid abundances to see possible shifts in community. Additionally, reach types and years were compared based on their overall 
fish community structure using analysis of similarity (ANOSIM) on Bray-Curtis distance coefficients (Bray and Curtis 1957, Merovich and Petty 2010). ANOSIM is a nonparametric test of significance between two or more groups based on a measure of distance between individual sites (Van Sickle and Hughes 2000). ANOSIM measures classification strength (CS) by subtracting the mean between-group similarity from the mean within-group similarity. Permutation tests $(10,000)$ were used to test the null hypothesis that fish communities are not affected by stream mitigation structures (Van Sickle 1997). Our fish community ANOSIM is displayed in a Nonmetric Multiple Dimensional Scaling (NMDS) ordination. NMDS ordinates sites based on similarities of fish community and vectors are added to see the influence of different variables (i.e. abundance, gamefish abundance, species richness, and biomass).

\section{Results}

The lower portion of the Little Coal River has homogenous landuse and there are no tributaries flowing into it. We tested local water quality during every sampling event at every sampling location; however, there was essentially no difference in variables between sampling events. Electrical conductivity $(n=47)$ average was $880 \pm 73$ varying only by year and season; $\mathrm{pH}(\mathrm{n}=47)$ was consistently $7.9 \pm 0.17$. Because of this, water quality is thought to be standardized across all reaches for a given sampling period and affected the entire river equally.

We found a significant effect of season, year, and substrate on macroinvertebrate abundance, WVSCI, \%EPT, and EPT richness (Table 1). There is a significant 
difference between spring and fall in all macroinvertebrate metrics; the average abundance for spring was 531 per $\mathrm{m}^{2}$ and 1474 per $\mathrm{m}^{2}$ in the fall for all substrate types. The average abundance for sand/silt samples was $87 \mathrm{per} \mathrm{m}^{2}$ and the cobble/gravel samples averaged 1918 per $\mathrm{m}^{2}$ for all seasons. Additionally, the average WVSCI in sand/silt samples in the spring was 27 and in the fall was 38; were the average WVSCI score for the cobble/gravel samples was 56 in the spring and 75 in the fall. There was no significant reach effect on macroinvertebrates. Sand substrate averaged $17 \%$ in the upper reach ranging from $12-25 \%$, the middle reach averaged $44 \%$ ranging from 38 $45 \%$, and the lower reach averaged $46 \%$; however, dropping $~ 25 \%$ in its first 2 years after construction (Figure 2). Habitat weighted abundance is calculated as the average number of macroinvertebrates you would expect to collect on any day of the year in any reach given the relative availability of specific habitats and habitat-specific abundance in that reach (Wallace et al. 1996). Because so few macroinvertebrates $\left(\sim 87 \mathrm{~m}^{2}\right)$ used sand and silt, habitat weighted abundance was driven by change in substrate, not the difference in macroinvertebrates per habitat type (Figure 2).

A total of 53 fish species and 1568 individuals were captured on the Little Coal River over the 6 year study period. Diversity and species richness had a significant reach effect, and total fish biomass was significantly different with respect to reach and year (Table 2). There was clearly lower biomass in the lower reach than the upper or middle reaches except for 2013. Also we observed lower fish biomass in the lower reach in comparison to pre-construction except for 2013 (Figure 3). Average fish biomass was also significantly different with respect to reach and year (Table 2). Total abundance 
had a reach effect as well as a reach-by-year interaction (Table 2). There was no significant effect with respect to gamefish; however, the lower reach was measurably lower after construction until 2014 (Figure 3). Sucker abundance had a reach and year effect; however, cyprinid abundance was not significantly influenced (Table 2). Gamefish biomass has been declining in the lower reach after construction of structures; however, staying consistent in the upper reach with slight year to year variation, but is highly variable in the middle reach (Figure 4). Sucker abundance and biomass has grown largely in the lower reach since 2012, had a large spike in the upper reach in 2014 , and has been highly variable in the middle reach; where other groups of fish, mostly cyprinids, have been negligible in every reach (Figure 4).

ANOSIM results indicate a significant dissimilarity $(P=0.0009)$ in fish community structure from 2009 to 2014 . There was a moderate separation among reaches with respect to year $(\mathrm{R}$-stat $=0.5809)$. We projected our ANOSIM results as a NMDS ordination and displayed in the first and second dimension with a stress value of 0.1653 (Figure 5).

\section{Discussion}

NCD structure construction had minimal influence on benthic macroinvertebrates in the Little Coal River. There were no differences between the upper, middle, and lower reach with respect to macroinvertebrates metrics. However, there was a difference between sand/silt substrate and cobble/gravel substrate. This was also seen as an increase in habitat weighted abundance due to the localized shifts of substrate by 
structure construction. However, this effect was small compared to the difference in season, with significantly higher invertebrate metrics in the fall.

The literature suggests that macroinvertebrate abundances based on season are highly variable. It's been shown that macroinvertebrate abundances are higher in the fall in large rivers and higher in the spring in smaller systems; Wipfli et al. (1998) found increases in macroinvertebrate abundances in the fall; however, the pattern was driven by spawning salmon. Linke et al. (1999) found no difference in macroinvertebrates between seasons and Cowan and Oswood (1984) found higher macroinvertebrate metrics in the spring in small streams. Although systems have different timing mechanisms for macroinvertebrate life history traits, the Little Coal River was consistently higher in the fall. There was high variability between years; however, we found a statistical year effect with respect to all invertebrate metrics. McElravy et al. (1989) confirms our results because they also found high variability between years in a long-term study. Furthermore, we found a statistical difference between sand/silt samples and cobble and gravel samples. Hopkins and Olson (2013) found that sand was the least productive of the five different substrates they sampled. These structures were designed to expose cobble and gravel substrate, they tend to be doing that at a local level (Chapter 1). Because cobble and gravel is increasing and sand is decreasing, we see an upward trend in the lower reach with respect to habitat weighted abundance. However, these results may be misleading. The structures create large scour pools beneath themselves. The exposed cobble and gravel is concentrated around these structures and scour pools. Unfortunately, due to flow and depth we are 
unable to sample these areas for macroinvertebrates, but we do know that pools have fewer macroinvertebrates than riffles (Brown and Brussock 1991). Therefore the location of the newly exposed cobble and gravel may still not be able to be used by benthic macroinvertebrate colonizers. We believe there is little to no benefit to macroinvertebrates with the installation of these structures, at least at the scale of the entire reach. However, WVSCI scores ranged from 27-75 depending on substrate type and time of year. Since we saw a WVSCI score of 75 in the cobble/gravel samples in the fall, this suggests to us the river may not be chemically impaired, but habitat limited and very much season dependent.

Fish species richness and diversity differed among study reaches. However, we observed no effect of structure construction (Figure 3). Total biomass was significantly different between reaches and years with respect to fish. Fish biomass in the middle reach seems to be far less variable then the upper or lower reach (Figure 3). The lower reach was consistently decreased until a spike in 2013 (the year after a drought). However, the upper reach seems to be steadily increasing every year (Figure 4). Clear patterns can be seen in fish community in the NMDS plot (Figure 5). The middle reach sites are concentrated on the right side of the plot every year. Interestingly, the lower reach in 2009 (pre-construction) was more similar to the upper reach sites. After construction the lower reach concentrated on the left side of the plot. Some of the factors influencing the placement of the sites and strongly correlated with the middle sites were abundance, gamefish abundance, species richness, and total biomass. After construction in the lower reach the fish assemblage moved further away from these 
factors. Although biomass was different between years abundance wasn't. Therefore the same number of fish just became heavier. In other words it seems many small fish were replaced by a few large fish. It appears to be large suckers moving into these deeper pools and smaller cyprinid species are being forced out. In pre-construction the majority of the biomass in the lower section was gamefish, now that there are deep pools created by structures that biomass is majority suckers, especially in 2013 (Figure $4)$.

It has been shown that large catastomidae can dominate analytical metrics (Osborne and Wiley 1992, Hitt and Angermeirer 2008). However, in smaller systems Detenbeck et al. (1992) found that centrarchids and cyprinids were the most resilient to a disturbance and often the first to recolonize an area. In contrast, Lepori et al. (2005) and Arango et al. (2015) found no change in fish community between restored and unrestored sites. Also, Haase et al. (2013) found only a positive effect of restoration on smaller sites and found a negative effect of restoration on large rivers when comparing them to upstream controls with respect to fish metrics. Game fish were not statistically different between reach and year; however, in the lower reach there was clearly more gamefish pre-construction than any year post-construction. Gamefish, typically trout, are common response variables to restoration in the literature. Trout have variable results with respect to abundance after restoration; there are studies that show a positive impact (Baldigo et al. 2008 and Whiteway et al. 2010), as well as a negative impact or no change (Johnson et al. 2005, Rosi-Marshall et al. 2006, Muotka and Syrjanen 2007, Pierce et al. 2015,). This variability in gamefish may be due to angling 
pressure on the Little Coal River. Anecdotally, we saw the number of fisherman greatly increase after construction of the structures. Every sampling event on the Little Coal River post-construction there were people present on the river, if not fishing they were swimming in newly developed scour pools. Studies have shown decreases in fish population due to angling (Hesse 1994, Blackford 2009, Murawski 2010) and may be the reason gamefish numbers have declined. Removal of gamefish may also free up resources for suckers as well.

There is much debate over the biological success of stream restoration success. To truly understand the effects of this project it must be compared to itself pre-construction. Typically in-stream restoration research is studied after the construction of the structure with little or no pre-construction data and determining success of a project in compromised without knowing pre-construction conditions (Bernhardt et al. 2007). Additionally, projects should be evaluated on the goals of that specific project (Lepori et al. 2005). The Little Coal River had well defined goals, the last of which was to increase fish and macroinvertebrate biodiversity. Raymond Dasmann (1968) coined the term biodiversity which can be interpreted differently by different scientist, but most see it as variety of life. We found that the structures failed at their goal, however with caveats. We found no measurable effect of structures on macroinvertebrates. The structures did shift substrate to expose more cobble and gravel, however we feel benthic macroinvertebrates cannot utilize this. Catastomidae's seem to be positively responding to structures and gamefish seem to be negatively responding. Although this was not the goal, we are detecting a change in fish assemblage. Palmer et al. (2007) 
argues that due to the variability of aquatic ecosystems, a measurable increase from restoration may be a signal of successful restoration. Although the Little Coal River project did not meet its expected goals over the 6 year study period, it is still unknown if that is sufficient time. Lund (1976), Edwards et al. (1984), and Muotka et al. (2002) all found biological responses to restoration at different time intervals, ranging from 1-9 years.

Although the Little Coal River project met many of its physical goals (Chapter 1); there are multiple reasons the project didn't fully meet its goals. In a large Appalachian river located in region of massive land transformations, water quality has to be addressed. The Environmental Protection Agency has set an electrical conductivity benchmark of impairment at $300 \mu \mathrm{s} / \mathrm{cm}$ and the Little Coal River was $\sim 850 \mu \mathrm{s} / \mathrm{cm}$ (Cormier et al. 2011). Petty and Merriam (2012) argue that restoration activities have to start with the dominant stressor first. Although there is a clear need for habitat restoration; when a system is chemically impaired, it negates any physical efforts. The dominant control of biota in aquatic systems is driven by water quality (Freund and Petty 2007) and without restoration chemical constraints a positive biological effects may not be seen. McClurg et al. (2007) and Petty et al. (2010) found that the regional conditions constrain biological response and that landscape conditions upstream are a dominant control on biological conditions downstream. This makes it difficult to expect localized restoration to have a biological effect in larger rivers due to the size of its drainage network. We saw no new fish move into the area post-construction; we observed fish assemblages shifting but by fish that were already present in the system. We believe a river this size 
should have far more fish than 1568 over a six year sampling period and this number may be due to chemical constraints and not allowing more intolerant fish to immigrate. WVSCI fall, cobble/gravel samples showed an average score of 75 (good); however, was poor for sand/silt samples and cobble/gravel samples in the spring. The fall cobble/gravel score could show that the Little Coal River is not as chemically impaired as we once believed and the biota is still habitat limited. 


\section{Literature Cited}

Arango, C. P., P.W. James, and K.B. Hatch. 2015. Rapid ecosystem response to restoration in an urban stream. Hydrobiologia, 749(1):197-211.

Baldigo, B. P., A.G. Ernst, D.R. Warren, and S.J. Miller. 2010. Variable responses of fish assemblages, habitat, and stability to natural-channel-design restoration in Catskill Mountain streams. Transactions of the American Fisheries society, 139(2):449467.

Baldigo, B. P., D.R.Warren, A.G. Ernst, and C.I. Mulvihill. 2008. Response of fish populations to natural channel design restoration in streams of the Catskill Mountains, New York. North American Journal of Fisheries Management, 28(3): 954-969.

Bernhardt, E.S., E.B. Sudduth, M.A. Palmer, J.D. Allan, J.L. Meyer, and G. Alexander. 2007. Restoring rivers one reach at a time: results from a survey of U.S. river protection practitioners. Restoration Ecology 15: 482-494.

Blackford, M. 2009. Fishers, Fishing, and Overfishing: American Experiences in Global Perspective, 1976-2006. Business History Review 82(3).

Bodkin, R., J. Kern, P. McClellan, A. Butt, and C. Martion. 2007. Limiting total dissolved solids to protect aquatic life. Journal of Soil and Water Conservation 62(3): 57A-61A.

Bray, J. R. and J.T. Curtis. 1957. An ordination of the upland forest communities of southern Wisconsin. Ecological monographs, 27(4):325-349.

Brown, A. V. and P.P. Brussock. 1991. Comparisons of benthic invertebrates between riffles and pools. Hydrobiologia, 220(2):99-108.

Cormier, S. M., G.W. Suter, L.L. Yuan, and L. Zheng. 2011. A field-based aquatic life benchmark for conductivity in central Appalachian streams (Vol. 23). EPA/600/R-10.

Cowan, C. A., and M.W. Oswood. 1984. Spatial and seasonal associations of benthic macroinvertebrates and detritus in an Alaskan subarctic stream. Polar biology, 3(4): 211-215.

Dasmann, R. F. 1968. A Different Kind of Country. MacMillan Company, New York

Detenbeck, N.E., P.W. DeVore, G.J. Niemi, and A. Lima. 1992. Recovery of temperate-stream fish communities from disturbance: a review of case studies and synthesis of theory. Environmental Management 16: 33-53. 
Edwards, C.J., B. L. Griswold, R. A. Tubb, E. C. Weber, and L.C. Woods. 1984. Mitigating effects of artificial riffles and pools on the fauna of a channelized warmwater stream. North American Journal of Fisheries Management 4:194-203.

Freund, J. G. and J.T. Petty. 2007. Response of fish and macroinvertebrate bioassessment indices to water chemistry in a mined Appalachian watershed. Environmental Management, 39(5): 707-720.

Gerritsen, J., J. Burton, and M.T. Barbour. 2000. A stream condition index for West Virginia wadeable streams. The University of Chicago PressOwings Mills. Maryland (Available from: http://www. dep. wv.gov/WWE/watershed/bio_fish/Documents/WVSCl. pdf).

Haase, P., D. Hering, S.C. Jähnig, A.W. Lorenz and A. Sundermann. 2013. The impact of hydromorphological restoration on river ecological status: a comparison of fish, benthic invertebrates, and macrophytes. Hydrobiologia, 704(1):475-488.

Hesse, L. W. 1994. The status of Nebraska fishes in the Missouri River, 4. Flathead catfish Pylodictis olivaris, and blue catfish, Ictalurus furcatus (Ictaluridae). Proceedings of the Nebraska Academy of Sciences 21:89-98.

Hilderbrand, R. H., A.C. Watts, and A.M. Randle. 2005. The myths of restoration ecology. Ecology and Society, 10(1):19.

Hitt, N. P. and P. L. Angermeier. 2008. Evidence for fish dispersal from spatial analysis of stream network topology .Journal of the North American Benthological Society 27:304-320.

Hopkins, $\mathrm{H}$. and A. Olson. 2013. Diversity and Abundance of Aquatic Macroinvertebrates Associated with Different Benthic Substrates in the East Branch of the Little Calumet River. Valaspo University.

Johnson, S.L., J.D. Rodgers, M.F. Solazzi, and T.E. Nickelson. 2005. Effects of an increase in large wood on abundance andsurvival of juvenile salmonids (Oncorhynchusspp.) in an Oregon coastal stream. Can. J. Fish. Aquat. Sci.62(2): 412-424.doi:10.1139/f04-222.

Kauffman, J. B., R.L. Beschta, N. Otting, and D. Lytjen. 1997. An ecological perspective of riparian and stream restoration in the western United States. Fisheries, 22(5):12-24.

Lepori, F., D. Palm, E. Brännäs, and B. Malmqvist. 2005. Does restoration of structural heterogeneity in streams enhance fish and macroinvertebrate diversity?.Ecological Applications, 15(6): 2060-2071. 
Linke, S., R.C. Bailey, and J. Schwindt. 1999. Temporal variability of stream bioassessments using benthic macroinvertebrates. Freshwater Biology, 42(3):575-584.

Lund, J.A. 1976. Evaluation of channelization and mitigation on the fishery resources of the St. Regis River, Montana.Fish and Wildlife Service, USDI.FWS/OBS76/06.Washington, D.C.

Magurran, A. E. 1996. Ecological diversity and its measurement, 2nd ed. Chapman and Hall, London. $179 \mathrm{pp}$.

McClurg, S. E., J.T. Petty, P.M. Mazik, and J.L. Clayton. 2007. Stream ecosystem response to limestone treatment in acid impacted watersheds of the Allegheny Plateau. Ecological Applications, 17(4): 1087-1104.

McElravy, E. P., G.A. Lamberti, and V. H. Resh. 1989. Year-to-year variation in the aquatic macroinvertebrate fauna of a northern California stream. Journal of the North American Benthological Society, 51-63.

Merovich, G.T. and J.T. Petty. 2010. Continuous response of benthic macroinvertebrate assemblages to a discrete disturbance gradient: consequences for diagnosing stressors. Journal of North American Benthological Society 29(4):12411257.

Merriam, E. R., J.T. Petty, M.P. Strager, A.E. Maxwell, and P.F. Ziemkiewicz. 2013. Scenario analysis predicts context-dependent stream response to landuse change in a heavily mined central Appalachian watershed. Freshwater Science, 32(4):1246-1259.

Merritt, R. W., and K. W. Cummins. 2008. An introduction to the aquatic insects of North America, Fourth edition. Kendall/Hunt Publishing Co., Dubuque, IA.

Miller, J. R. and R.C. Koche. 2010. Assessment of channel dynamics, in-stream structures and post-project channel adjustments in North Carolina and its implications to effective stream restoration. Environmental Earth Sciences, 59(8):1681-1692.

Miller, S. W., P. Budy, and J.C. Schmidt. 2010. Quantifying Macroinvertebrate Responses to In-Stream Habitat Restoration: Applications of Meta-Analysis to River Restoration. Restoration Ecology, 18(1):8-19.

Miller, A. C., R. H. King, and J. E. Glover. 1983. Design of a gravel bar habitat for the Tombigbee River near Columbus, Mississippi. Miscellaneous Paper EL-83- 1. US Army Engineer Waterways Experiment Station, Vicksburg, MS.

Muotka, T. and J. SYRJÄNEN. 2007. Changes in habitat structure, benthic invertebrate diversity, trout populations and ecosystem processes in restored forest streams: a boreal perspective. Freshwater Biology, 52(4):724-737. 
Muotka, T., R. Paavola, A. Haapala, M. Novikmec, M., and P. Laasonen. 2002. Long-term recovery of stream habitat structure and benthic invertebrate communities from in-stream restoration. Biological Conservation, 105(2):243-253.

Murawski, S.A. 2010. Rebuilding depleted fish stocks: the good, the bad, and, mostly, the ugly. ICES Journal of Marine Science 67:1830-1840.

Osborne, L. L. and M.J. Wiley.1992. Influence of tributary spatial position on the structure of warmwater fish communities. Canadian Journal of Fisheries and Aquatic Sciences, 49(4):671-681.

Palmer, M. A. and K.L. Hondula. 2014. Restoration as mitigation: analysis of stream mitigation for coal mining impacts in southern Appalachia. Environmental science \& technology, 48(18):10552-10560.

Palmer, M., J.D. Allan, J. Meyer, and E.S. Bernhardt. 2007. River restoration in the twenty-first century: data and experiential knowledge to inform future efforts. Restoration Ecology, 15(3):472-481.

Peckarsky, B. L., P. R. Fraissinet, M. A. Penton, and J. Conklin, D. J. 1990. Freshwater macroinvertebrates of Northeastern North America.CornellUniversity Press, Ithaca.

Petty, J. T. and E.R. Merriam. 2012. Brook trout restoration. Nature Education Knowledge, 3(7):17.

Petty, J. T., J.B. Fulton, M.P. Strager, G.T. Merovich Jr, J.M. Stiles, and P.F. Ziemkiewicz. 2010. Landscape indicators and thresholds of stream ecological impairment in an intensively mined Appalachian watershed. Journal of the North American Benthological Society, 29(4):1292-1309.

Pierce, R., C. Podner, and L. Jones. 2015. Long-Term Increases in Trout Abundance following Channel Reconstruction, Instream Wood Placement, and Livestock Removal from a Spring Creek in the Blackfoot Basin, Montana. Transactions of the American Fisheries Society, 144(1):184-195.

Poplar-Jeffers, I. O., J.T. Petty, J. T. Anderson, S.J. Kite, M.P. Strager, and R.H. Fortney.2009. Culvert replacement and stream habitat restoration: implications from brook trout management in an Appalachian watershed, USA. Restoration Ecology, 17(3), 404-413.

R Core Team 2014. R: A language and environment for statistical computing. R Foundation for Statistical Computing, Vienna, Austria. 
Rosenberg, D. M. and V.H. Resh. 1993. Freshwater biomonitoring and benthic macroinvertebrates. Chapman \& Hall.

Rosgen, D.L. 1998. The reference reach: A blueprint for natural channel design. In Engineering Approaches to Ecosystem Restoration (pp. 1009-1016). ASCE.

Rosgen, D. L. 2001. The cross-vane, w-weir and j-hook vane structures... their description, design and application for stream stabilization and river restoration. Amer. Assoc. Civil Engrs., Restoration Proceedings, Reno, Nevada.

Rosi-Marshall, E.J., A.H. Moerke, and G.A. Lamberti. 2006. Ecological responses to trout habitat rehabilitation in a northern Michigan stream. Environ. Manage.38(1): 99107.

Thompson, D. M. and G.N. Stull. 2002. The development and historic use of habitat structures in channel restoration in the United States: the grand experiment in fisheries management. Géographie physique et Quaternaire, 56(1):45-60.

Van Sickle, J. 1997. Using mean similarity dendrograms to evaluate classifications. Journal of Agricultural, Biological, and Environmental Statistics 2(4):370-388.

Van Sickle, J. and R. M. Hughes. 2000. Classification strengths of ecoregions, catchments and geographic clusters for aquatic vertebrates in Oregon. Journal of the North American Benthological Society 19(3):370-384.

Wallace, J. B., J.W. Grubaugh, and M.R. Whiles. 1996. Biotic indices and stream ecosystem processes: results from an experimental study. Ecological applications,140151.

Whiteway, S. L., P.M. Biron, A. Zimmermann, O. Venter, and J.W. Grant. 2010. Do in-stream restoration structures enhance salmonid abundance? A meta-analysis. Canadian Journal of Fisheries and Aquatic Sciences, 67(5):831-841.

Wipfli, M. S., J. Hudson, and J. Caouette. 1998. Influence of salmon carcasses on stream productivity: response of biofilm and benthic macroinvertebrates in southeastern Alaska, USA. Canadian Journal of Fisheries and Aquatic Sciences, 55(6):1503-1511.

WVDEP (West Virginia Department of Environmental Protection). 2009. Standard operating procedures. West Virginia Department of Environmental Protection, Charleston, West Virginia. 


\section{Tables and Figures}

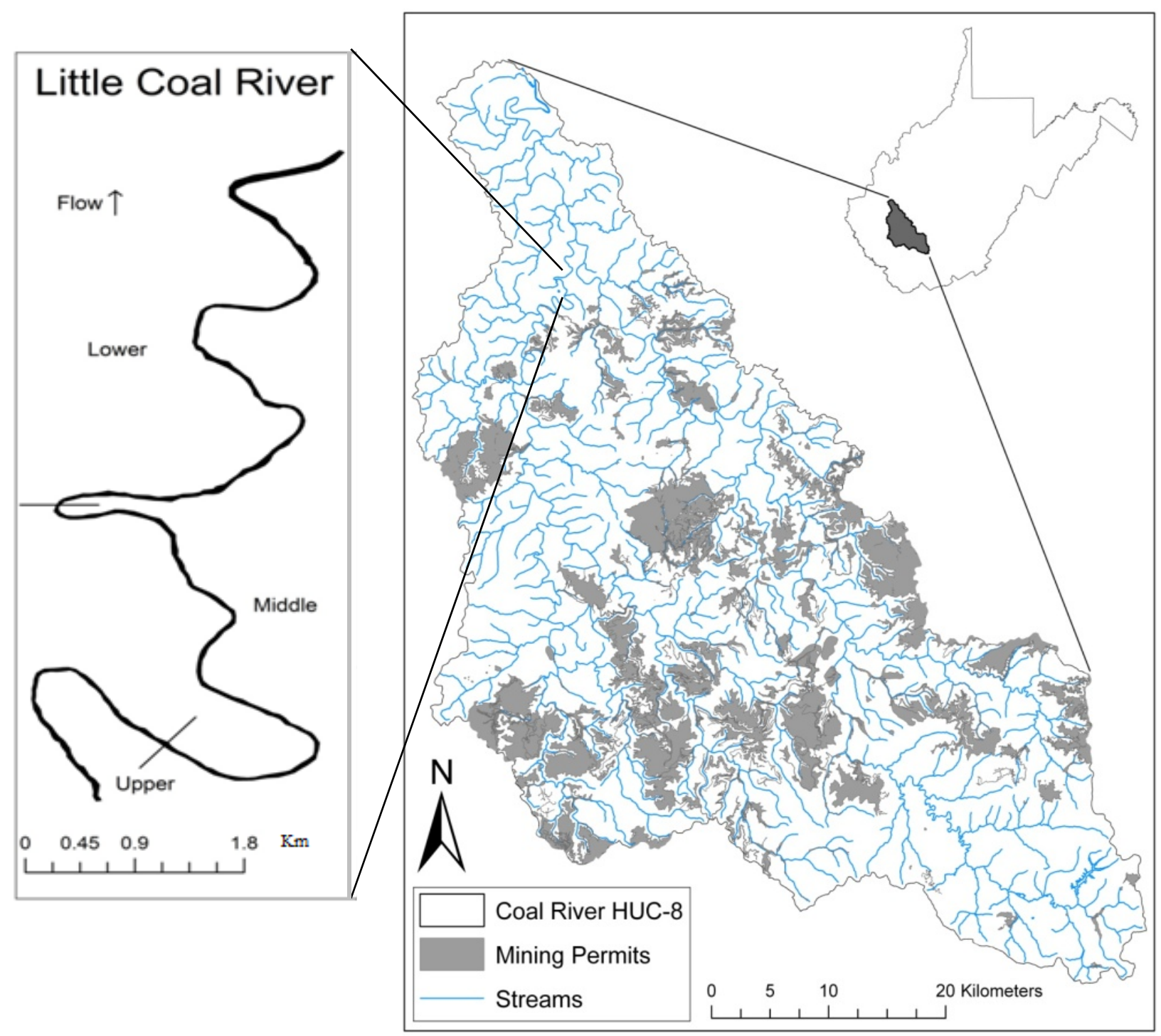

Figure 1. Map of study area with upper, middle, and lower study segments delineated. 
Table 1. ANOVA results of macroinvertebrate parameters; abundance, West Virginia Stream Condtion Index (WVSCI), percent ephemeroptera, plecoptera, and trichoptera (\% EPT), and ephemeroptera, plecoptera, and trichoptera (EPT) richness with respect to reach, season, year, and substrate. Significant values are bolded.

\begin{tabular}{llccccc}
\hline Parameter & Variable & Df & Sum Sq & Mean Sq & F-Value & P-Value \\
\hline Abundance & Reach & 2 & 2245804 & 1122902 & 1.048 & 0.351 \\
& Season & 1 & 119708962 & 119708962 & 111.777 & $<\mathbf{0 . 0 0 1}$ \\
& Year & 5 & 69094546 & 13818909 & 12.903 & $<\mathbf{0 . 0 0 1}$ \\
& Substrate & 1 & 454236033 & 454236033 & 424.137 & $<\mathbf{0 . 0 0 1}$ \\
& Residuals & 528 & 565469046 & 1070964 & & \\
WVSCI & Reach & 2 & 4 & 2 & 0.022 & 0.978 \\
& Season & 1 & 19061 & 19061 & 237.088 & $<\mathbf{0 . 0 0 1}$ \\
& Year & 5 & 5711 & 1142 & 14.207 & $<\mathbf{0 . 0 0 1}$ \\
& Substrate & 1 & 133840 & 133840 & 1664.77 & $<\mathbf{0 . 0 0 1}$ \\
& Residuals & 528 & 42449 & 80 & & \\
& Reach & 2 & 684 & 342 & 1.308 & 0.271 \\
& Season & 1 & 66811 & 66811 & 255.409 & $<\mathbf{0 . 0 0 1}$ \\
& Year & 5 & 15230 & 3046 & 11.645 & $<\mathbf{0 . 0 0 1}$ \\
& Substrate & 1 & 330355 & 330355 & 1262.9 & $<\mathbf{0 . 0 0 1}$ \\
& Residuals & 528 & 138116 & 262 & & \\
EPT Richness & Reach & 2 & 4.5 & 2.2 & 0.844 & 0.43 \\
& Season & 1 & 93.9 & 93.9 & 35.451 & $<\mathbf{0 . 0 0 1}$ \\
& Year & 5 & 344.3 & 68.9 & 25.987 & $<\mathbf{0 . 0 0 1}$ \\
& Substrate & 1 & 2655 & 2655 & 1002.11 & $<\mathbf{0 . 0 0 1}$ \\
& Residuals & 528 & 1398.9 & 2.6 & & \\
\hline
\end{tabular}


Figure 2. Percent of sand and macroinvertebrate habitat weighted abundance with respect to year and reach; black squares are the lower reach (2009 is pre-construction), open triangles are the upper reach, and open circles are the middle reach.
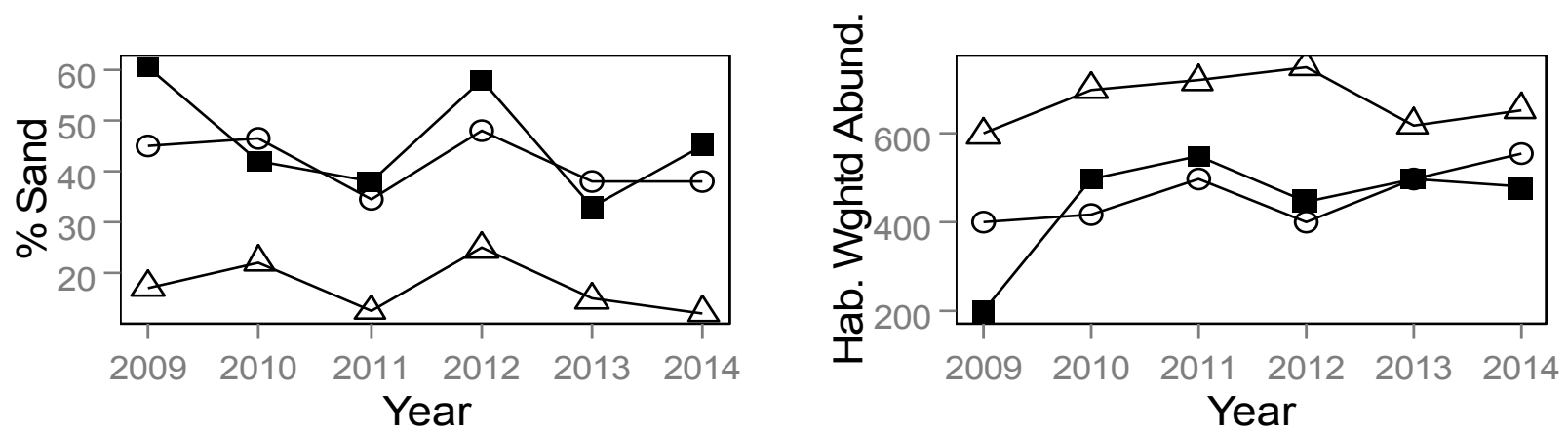
Table 2. ANOVA results of fish parameters; diversity, species richness, total biomass, average biomass, total abundance, gamefish abundance, sucker abundance, and cyprinid abundance with respect to year and reach. Significant values are bolded.

\begin{tabular}{|c|c|c|c|c|c|c|}
\hline Parameter & Variable & Df & Sum Sq & Mean Sq & F-Value & P-Value \\
\hline \multirow[t]{4}{*}{ Diversity } & Reach & 2 & 0.519 & 0.2595 & 5.633 & 0.0188 \\
\hline & Year & 5 & 0.1002 & 0.1002 & 2.176 & 0.166 \\
\hline & Reach:Year & 10 & 0.1968 & 0.0984 & 2.136 & 0.1608 \\
\hline & Residuals & 12 & 0.5528 & 0.0461 & & \\
\hline \multirow[t]{4}{*}{ Species Richness } & Reach & 2 & 412.1 & 206.06 & 18.128 & 0.0002 \\
\hline & Year & 5 & 4.3 & 4.29 & 0.377 & 0.5507 \\
\hline & Reach:Year & 10 & 4.3 & 2.16 & 0.19 & 0.8296 \\
\hline & Residuals & 12 & 136.4 & 11.37 & & \\
\hline \multirow[t]{4}{*}{ Total Biomass } & Reach & 2 & 616.4 & 308.22 & 7.209 & 0.0088 \\
\hline & Year & 5 & 227.1 & 227.12 & 5.312 & 0.0399 \\
\hline & Reach:Year & 10 & 169.6 & 84.78 & 1.983 & 0.1803 \\
\hline & Residuals & 12 & 513.1 & 42.75 & & \\
\hline \multirow[t]{4}{*}{ Average Biomass } & Reach & 2 & 25218 & 12609 & 2.945 & 0.0911 \\
\hline & Year & 5 & 15984 & 15984 & 3.733 & 0.0773 \\
\hline & Reach:Year & 10 & 4141 & 2070 & 0.484 & 0.6281 \\
\hline & Residuals & 12 & 51379 & 4282 & & \\
\hline \multirow[t]{4}{*}{ Total Abundance } & Reach & 2 & 13756 & 6878 & 4.822 & 0.029 \\
\hline & Year & 5 & 51 & 51 & 0.035 & 0.8539 \\
\hline & Reach:Year & 10 & 10083 & 5041 & 3.534 & 0.0621 \\
\hline & Residuals & 12 & 17117 & 1426 & & \\
\hline \multirow[t]{4}{*}{ Game Fish Abundance } & Reach & 2 & 74.8 & 37.39 & 1.264 & 0.318 \\
\hline & Year & 5 & 13.9 & 13.89 & 0.469 & 0.506 \\
\hline & Reach:Year & 10 & 16.8 & 8.41 & 0.284 & 0.757 \\
\hline & Residuals & 12 & 355 & 29.58 & & \\
\hline \multirow[t]{4}{*}{ Sucker Abundance } & Reach & 2 & 708.1 & 354.1 & 8.334 & 0.0054 \\
\hline & Year & 5 & 334.4 & 334.4 & 7.871 & 0.0159 \\
\hline & Reach:Year & 10 & 105.3 & 52.6 & 1.239 & 0.3243 \\
\hline & Residuals & 12 & 509.8 & 42.5 & & \\
\hline \multirow[t]{4}{*}{ Cyprinid Abundance } & Reach & 2 & 4505 & 2252.4 & 2.254 & 0.1476 \\
\hline & Year & 5 & 14 & 13.9 & 0.014 & 0.9081 \\
\hline & Reach:Year & 10 & 5876 & 2938 & 2.94 & 0.0914 \\
\hline & Residuals & 12 & 11992 & 999.4 & & \\
\hline
\end{tabular}



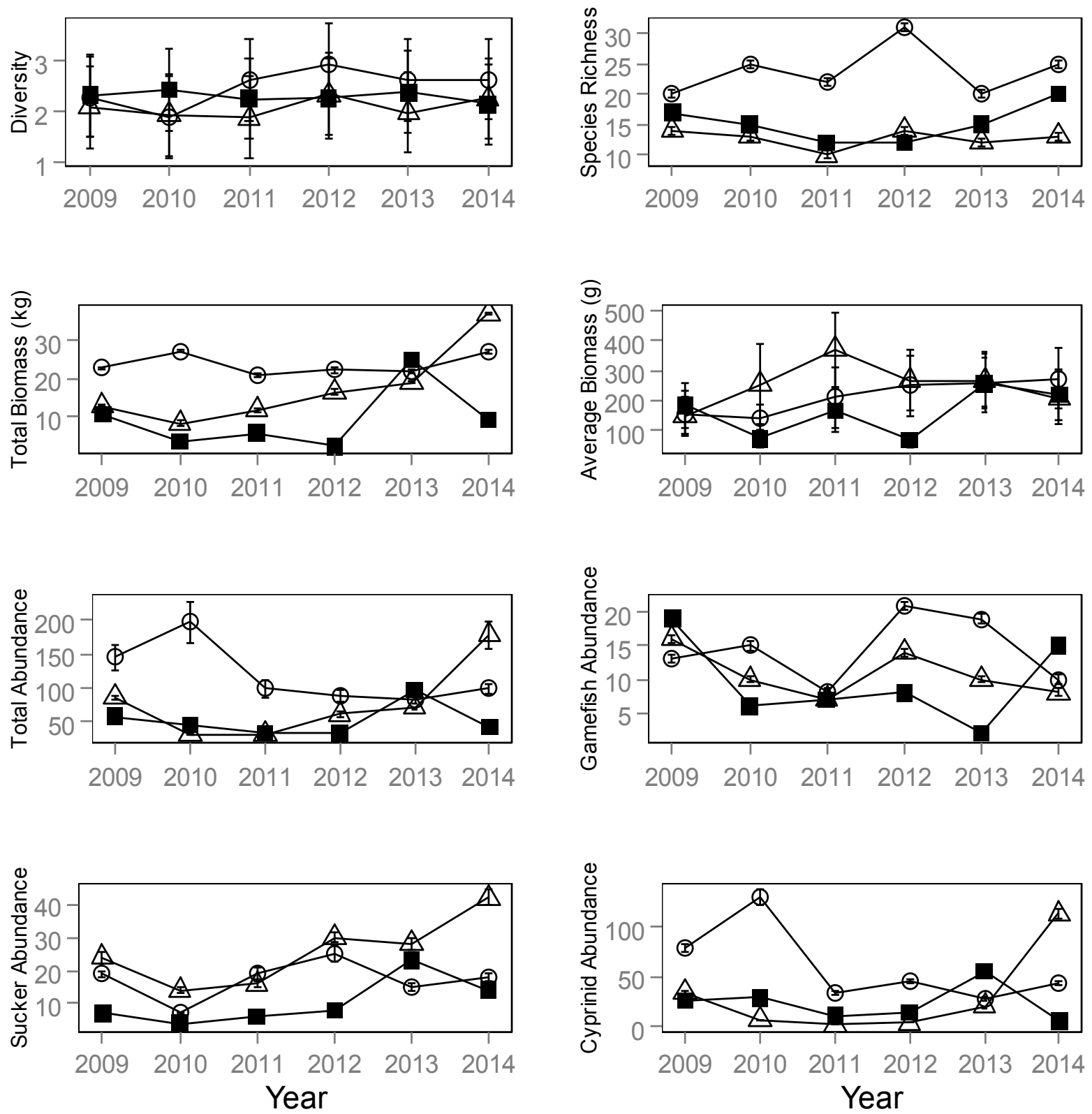

Figure 3. Means (SE) of fish parameters with respect to year and reach; black squares are the lower reach (2009 was pre-construction), open triangles are the upper reach, and open circles are the middle reach. 

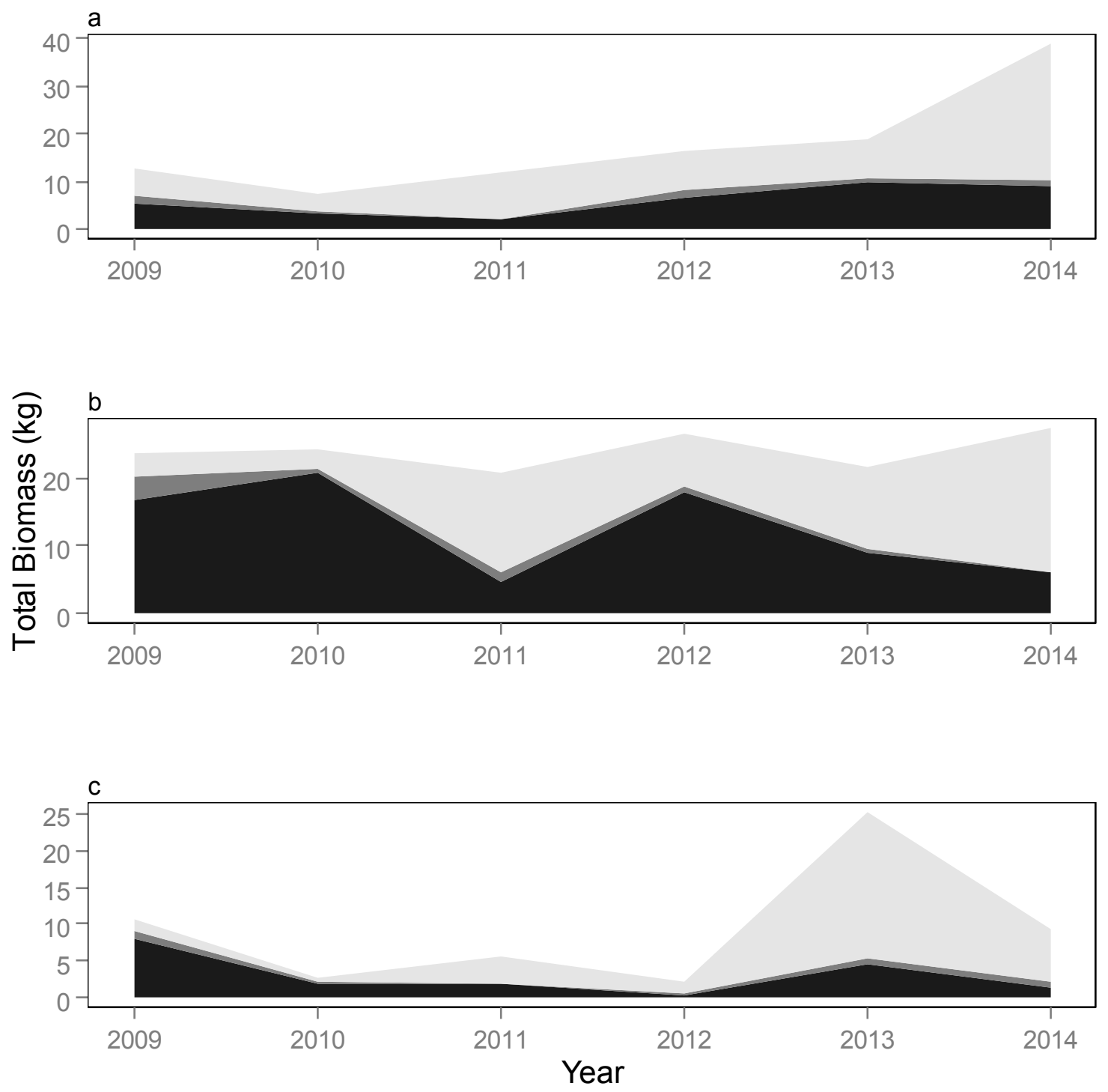

Figure 4. Total biomass of fish caught, separated by gamefish (black), others (dark gray), and suckers (light gray) with respect to year; $a=$ upper reach, $b=$ middle reach, and $c=$ lower reach (2009 was pre-construction). 


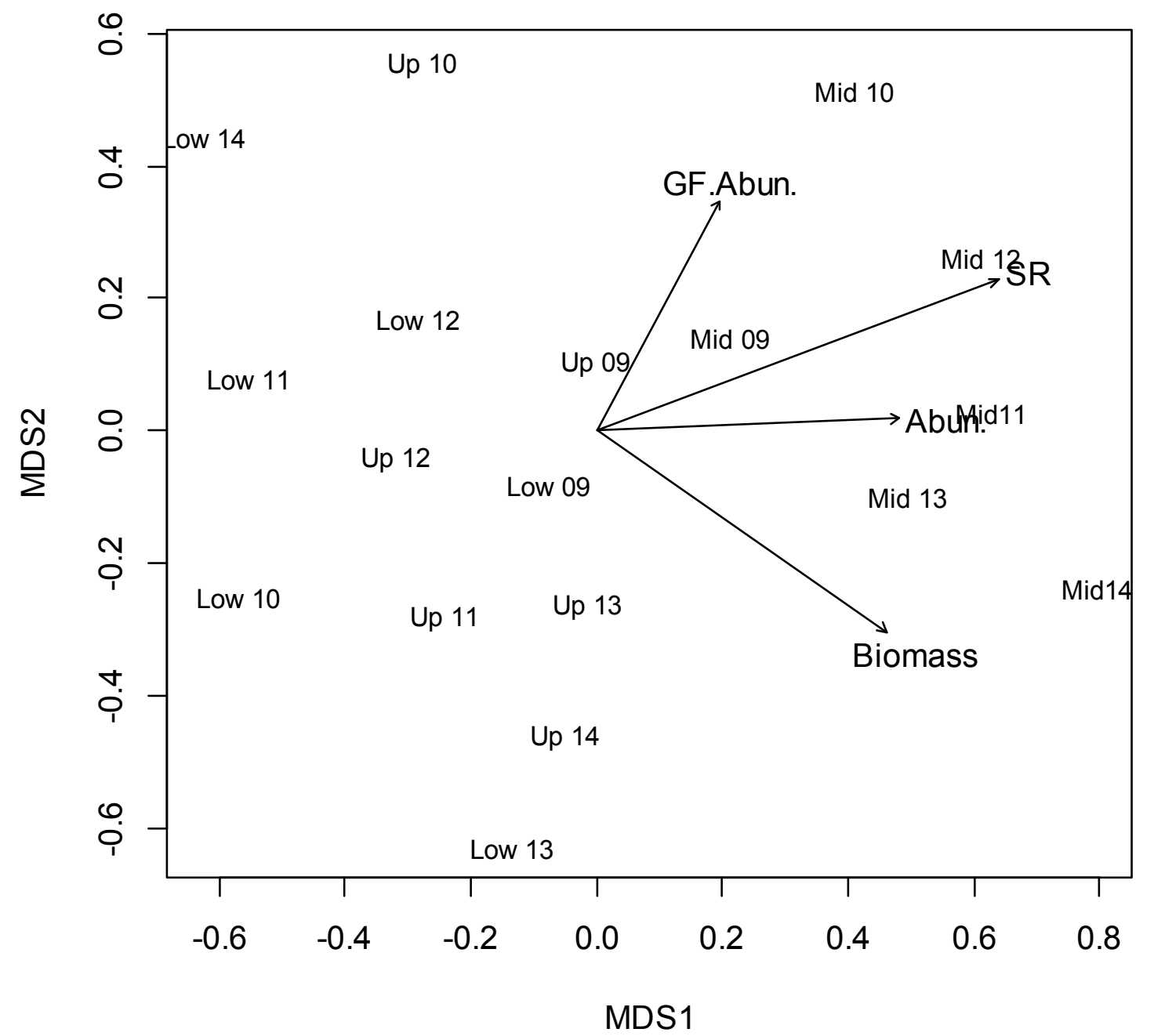

Figure 5. A NMDS plot of fish community structure based on reach and year. The five sites within each reach were combined for total community structure measurement. Low=Lower reach, Mid=Middle reach, and Up= Upper reach and the number represeant the year. Vectors show direction of each variable. GF.Abun=Gamefish Abundance, $\mathrm{SR}=$ Species Richness, Abun.=Abundance. 
CHAPTER 3: CONTEXT-DEPENDENT EFFECTIVENESS OF STREAM RESTORATION IN MINED APPALACHIAN WATERSHEDS

Eric Miller* and J. Todd Petty

School of Natural Resources, West Virginia University, Morgantown, WV 26506

*Corresponding Author: Emiller9@mix.wvu.edu 


\section{Abstract}

Due to extensive large-scale surface mining (aka mountaintop mining), southern West Virginia is a highly concentrated area for reach-scale stream restoration projects that typically consist of natural stream channel design structures. The overall benefits of these projects to recover lost aquatic ecosystem functions are largely unknown. In this study we quantified physical and biological (fishes and macroinvertebrates) response to restoration on 14 streams across a range of conditions, including: drainage area, water quality, and the condition of surrounding streams. Our results suggest that typical restoration practices consistently improve physical habitat quality regardless of stream size. Restored reaches generally have higher habitat condition scores than adjacent reference reaches and tend to be higher than the average reach in the region. In contrast, macroinvertebrate assemblages demonstrated no measurable positive response to physical habitat restoration, regardless of stream size, water quality, or the condition of neighboring streams. Finally, fish assemblage response to restoration was strongly context dependent. Restoration projects on larger streams (i.e. $>10 \mathrm{~km}^{2}$ drainage area) with lower electrical conductivity $(<1000)$ tended to result in a more positive response by fishes than projects on small, high electrical conductivity streams. However, the most consistent response by fishes to restoration was an increased abundance and biomass of tolerant taxa. We did not observe a systematic benefit of restoration to pollution intolerant taxa, even in streams with good water quality. Taken on a whole, our results support the hypothesis that the benefits of physical habitat restoration depend on stream size and water quality, and consequently, a piecemeal approach to restoration is expected to produce minimal improvements to aquatic 
ecosystem conditions in mined Appalachian watersheds. Instead, a strategic approach that couples water quality improvements with physical habitat restoration at a watershed scale should be pursued.

Key words: stream restoration, mitigation, In-stream structures, Mountain-top removal and valley fill mining 


\section{Introduction}

Stream habitat restoration has grown exponentially worldwide over the past few decades (Bernhardt et al. 2005). The increase in projects is in part due to the increase in landuse change and the conversion of natural lands to a landscape more beneficial to human need (Heald and Spracklen 2015). Because of this landuse change and impacts to streams, environmental protection agencies require stream restoration projects that can take many different forms across the world. Projects can address the chemical, biological, and physical restoration of streams or a combination (Kauffman et al 1997).

The central Appalachian region has extensive impacts that affect stream ecosystems from a combination of historic and contemporary activities (Petty et al. 2010, Merriam et al. 2011, Merovich et al. 2013). The steep topography of southern West Virginia restricts many development activities to the narrow valleys, which also contain vulnerable streams. The major development of the areas is surface mining, which is transforming the state's steep topography to large flat plateaus or valley fills (Petty et al. 2013). Valley fills are becoming more common and larger. For example, a $3.2 \mathrm{~km}$ long and $48.6 \mathrm{~km}^{2}$ valley fill is associated with one of West Virginia's largest mines, Hobet 21 mine (Mitchell 2006). In 2010 surface mining and valley fills were responsible for $>772$ $\mathrm{km}$ of headwater streams being filled (Shank 2010) and 67\% of southern West Virginia streams being impacted by mining (Merriam et al. 2015). To compensate for mining related impacts the state requires stream mitigation to be implemented. There are many activities that are encompassed in the mitigation definition (settling ponds, 
culverts, planting, etc.), but southern West Virginia has a high concentration of instream or natural channel design (NCD) structures. Indeed, there have been over 100 mitigation projects implemented in the last decade in this region alone.

In-stream mitigation has been conducted in the United States for over 80 years to offset anthropogenic influences (Thompson and Stull 2002). In-stream mitigation includes cross-vanes, j-hooks, w-weirs, rock vanes, wing deflectors, k-dams, and many more. Specific goals of steam mitigation projects vary greatly. However, the ultimate underlying goal of mitigation project is to improve physical habitat conditions at the site and jumpstart natural ecological processes (Palmer 2004). Projects have been rated as having succeeded or failed based on many criteria (decrease in erosion, increase in bed complexity, scour pool relocation, floodplain reconnection, etc.) with equivocal results, not only in the mountaintop mining region, but also worldwide.

Typically, bioindicators are used as proxies for in-stream mitigation success (Dolédec et al. 2015). For example, Roni et al. (2008), Whiteway et al. (2010), Polivka et al. (2014), and Roni et al. (2014), found in-stream structure placement and pool development increased salmonid fish metrics. However, Stanko et al. (2012), Nilsson et al. (2014), and Arango et al. (2015) all found little or no response by fishes to stream restoration activities. The same equivocal results can be found in macroinvertebrates where equal numbers of positive and negative responses to stream restoration have been observed (Muotka et al. 2002, Harrison et al. 2004, Miller et al. 2010). Many 
things could be leading to ambiguous and contradicting results, but Palmer et al. (1997) argues that due to the variability of aquatic ecosystems, any measurable increase from restoration may be a signal of successful restoration.

Restoration outcomes and measuring the response of some biotic process can be difficult, spatially and temporally. Determining the time in which one expects to see a recovery of species can be difficult. For example, Lund (1976) and Edwards et al. (1984) found that it takes $1-5$ years for fish populations to recover from mitigation processes such as boulder placement, pool construction, and artificial riffle construction. Therefore, many studies may be too early to see a response. Local effects such as incomplete habitat restoration (Roni et al. 2008), the flourishing of exotics (Poff et al. 1997), and water quality (Violin et al. 2011) can decrease the effects of physical restoration on biota. Also constraints on the landscape may limit project success. For example, Gellert et al. (2012) applied the term "spreading effect" to mean that the condition of the surrounding area may constrain restoration benefits locally. Additionally, Loernz and Feld (2013) argue that the upstream condition of the restoration site is the driving factor to what is observed at the project.

Southern West Virginia is affected from not only surface mining but un-serviced development (failed septic systems, sanitary and "grey water" straight pipes; Merriam et al. 2011). These land uses have been shown to increase chemical stressors, which negatively affect stream fish and macroinvertebrates (Pond et al. 2008, Merriam et al. 2011, Bernhardt et al. 2012, and Kuchapski and Rasmussen 2015). Although the area 
is highly concentrated with anthropogenic impacts, there is a large number of people and projects attempting to better the aquatic ecosystems.

Our objectives were to quantify the physical and biological responses to in-stream mitigation over a range of stream sizes and upstream land use conditions. We examined habitat variables, water quality, fish, and benthic macroinvertebrate as measures of ecological function. We expected a reduction in effect of biological responses with an increase in poor water quality and human land use intensity.

\section{Study Area and Site Selection}

We selected 14 mitigation sites in streams ranging from $2.7 \mathrm{~km}^{2}-221 \mathrm{~km}^{2}$ in drainage area across 6 southern counties in West Virginia where mountaintop mining impacts are prevalent (Figure 1). Each site was visited with the accompaniment of the West Virginia Department of Environmental Protection (WVDEP) and the practitioners, Appalachian Stream Restoration, to verify that the site met our needs. The site had to be perennial, have in-stream structures, and the length of the restored reach length had to be at least 40 times the mean stream width (MSW). Thirteen projects were existing prior to the beginning of the study. An additional project was installed in fall 2010 , so we were able to sample this site before and after project implementation. Additionally, we selected 10 independent reference sites distributed across the region and across a range of land use activity (i.e., unimpacted, mined, and developed; Merriam et al. 2015). These regional reference sites had no mitigation action planned for them and were selected to be generally representative of aquatic ecosystem conditions in the area (Figure 1). 


\section{Methods}

Thirteen sites had projects on the ground before sampling and ranged from six months to seven years in age in 2011. At each of these sites, measurements were taken at the mitigation site and a paired control section above the mitigated area. Since we did not have pre-construction data for these sites, we worked under the assumption that the control reach was comparable to the mitigated site pre-construction (Haase et al. 2013). We use a standardized length of $40 x$ MSW for sampling both the mitigated and paired control reaches. An unsampled distance between the two reaches was also 40x MSW. One projects' restoration plan was implemented in the spring of 2012. In 2011 measurements were taken before construction began at the study site. After construction measurements were taken at the new mitigation site. The same 40x MSW measurement was used for this site.

\section{Field Methods}

Water samples and benthic macroinvertebrates were collected in May 2011, 2012, 2013; fish and habitat data were collected in August 2011, 2012, and 2013. All field methods were conducted at each regional reference $(n=10)$, mitigated stream reach $(n=14)$, and paired control reach $(n=14)$.

\section{Rapid visual Habitat Assessment and Water Quality}

Rapid Visual Habitat Assessment (RVHA) is a simple visual method to assess physical habitat conditions (Barbour 1999). Scores range from 0-20 for 10 different criteria. 
Categories include: epifaunal substrate, embeddedness, depth regime, sediment deposition, channel flow status, channel alteration, frequency of riffles, bank stability, vegetation protection, and riparian zone width. For consistency, the same team of people completed the assessment at all sites. Any time we were at the site water quality measurements were collected using a multi-parameter YSI 650 unit fitted with a 600XL snode (Yellow Springs Instruments (YSI), Yellow Springs, OH, USA). The YSI measured temperature $\left({ }^{\circ} \mathrm{C}\right), \mathrm{pH}$, specific electrical conductivity $(\mu \mathrm{s} / \mathrm{cm})$, dissolved oxygen ( $\mathrm{mg} / \mathrm{L})$ and total dissolved solids ( $\mathrm{g} / \mathrm{L})$.

\section{Benthic Macroinvertebrate Assemblages}

Benthic macroinvertebrates were collected from 4 different riffles within each reach (Barbour et al. 1999, Merriam et al. 2011). We sampled using a kick net with a 500 um mesh and dimensions of $335 \times 508 \mathrm{~mm}$. Within each area a $0.25 \mathrm{~m}^{2}$ region of stream bed was disturbed to insure that the majority of the macroinvertebrates are collected. A "kick" consists of placing the net beneath a riffle and vigorously disturbing the substrate. After the completion of four kicks samples from each site, the contents of the kick net were preserved in $95 \%$ ethanol. The net was thoroughly cleaned before collecting at the next site. A total of 114 macroinvertebrate samples were collected over the couse of our study.

\section{Fish Assemblages}

Fishes were collected using backpack electro-shockers and an electro-fishing barge provided by the WVDEP. Single pass electrofishing was completed at each study reach 
using a Smith-Root LR-24 and was typically completed by a four person team (one shocker, two netters, and one spotter). Most sites required only a single backpack shocker; however Gilbert Creek did require two and required a six person team. The barge was only used at one site (Paint Creek) because of its width. The barge was designed by the WVDEP and consisted of a centrally located Smith-Root generator and two anodes powered by the generator. Sampling Paint Creek required an eight person team. Species type, total length, and weight were recorded for all fish. All fish were identified in the field by WVDEP and WVU fish experts; therefore, we did not have to bring any fish back for identification. A total of 16,372 individuals and 57 species were captured during our study.

\section{Laboratory methods}

Benthic Macroinvertebrates

WVDEP (2009) protocol was used for macroinvertebrate laboratory methods. The benthic macroinvertebrate samples were rinsed in a $500 \mu \mathrm{m}$ sieve and then placed into a custom gridded sorting tray. The sorting tray is $12.7 \mathrm{~cm}$ (5 in) by $50.8 \mathrm{~cm}$ (20 in) and divided into 100 equal square centimeters. Random numbers are then drawn and that sample is collected $2.5 \mathrm{~cm}^{2}\left(1 \mathrm{in}^{2}\right)$ at a time. To ensure proper extraction of the square inch a custom square inch "cookie cutter" is placed straight down to the selected number. The sample is extracted and placed into a petri dish. Macroinvertebrates are counted and samples are pulled until 160-240 inverts are collected. Benthic macroinvertebrates are then identified to the genus or the lowest possible level using Peckarsky et al. (1990) and Merritt and Cummins (2008). Identified macroinvertebrates 
were then entered into the West Virginia stream condition index (WVSCl) calculator which is West Virginia's family level IBI (Gerritsen et al. 2000) and Genus-Level Index of Most Probable Stream Status (GLIMPSS) which is the genus level IBI (Pond et al. 2008).

\section{Statistical Analysis}

To better understand the effects of mitigation and account for natural variation in aquatic systems we used the means of the three years for analysis. Our pre-construction stream, Big Fork, had only one year of pre-construction data and two years of postconstruction. Therefore we used the pre-construction value as its control values and the mean of 2011 and 2012 as its mitigation values. The variables selected were chosen from data from Anderson et al. (2015) as well as additional variables that we felt may be important. Anderson et al. (2015) found that select fish variables were important factors in predicting stream condition in the southern coalfields of West Virginia; therefore we adopted those same variables.

To take advantage of the paired nature of our study we conducted a series of MannWhitney U-test to test the hypotheses' that the mitigated portion of a stream is statistically different than its paired control with respect to habitat, macroinvertebrates, and fish variables. We also performed correlations as a statistical test of the relationship between response variables and drainage area and conductivity. Additionally, we used Akaike Information Criteria (AIC) to determine the best predictors to explain our response variables. The predictor variables used for AIC were; drainage 
area, conductivity, swim distance (stream distance to accumulated $200 \mathrm{~km}^{2}$ stream), development condition, and mining condition. Development and mining condition scores represent the neighborhood condition of each site. The neighborhood of each site is defined as 12-digit HUC in which each site lies. The condition scores are the PC scores derived from the accumulated landscape of the outflow of each 12-digit HUC (Anderson et al. 2015).

We only performed AIC on the variables found to be statistically different in the U-test. Our candidate models were each predictor variable individually as well as a models that had the interaction between electrical conductivity and drainage area and an interaction model between mining condition and development condition. These individual predictor models and interactive models were selected a priori. We chose the interactive models based on the knowledge of the area and knowing drainage area and local electrical conductivity affect the local biota. Lastly, we performed ANCOVA on all response variables using electrical conductivity and drainage area as covariates and site type as predictor variables; thus analysis included mitigated, control, and reference reaches. We performed ANCOVA's on all fish variables using raw data as well as adjusted values (with respect to drainage area) and electrical conductivity being the covariate. These adjusted values are the observed values divided by the expected values for a given size drainage area. The expected values were based from Anderson et al. (2015). An alpha level of 0.1 was used because of the variable nature of the aquatic systems and low sample size (Bryant et al. 2004, Al-Chokhachy et al. 2010, and Miller et al. 2010). 


\section{Results}

Pairwise comparisons identified several aquatic ecosystem variables that differed significantly between mitigated and paired control sites (Table 1). Habitat score was shown to be significantly higher in the mitigated area compared to the paired control reaches. No benthic macroinvertebrate metrics were found to be statistically different between the pairs. Mann-Whitney $U$ tests found that diversity, abundance, gamefish abundance, total biomass, $\%$ cyprinid, $\%$ tolerant species, cyprinid richness, tolerant cyprinid richness, cyprinid richness minus blacknose dace (Rhinichthys atratulus) or creek chubs (Semotilus atromaculatus), and invertivore richness, were all significantly different between mitigated reaches and their paired control reach (Table 1). The means of each variable show that the mitigated reach was higher in all categories than the control reaches.

Correlations between fish variables and electrical conductivity revealed \% invertivore/piscivore minus creek chubs, tolerant species, cyprinid richness, and tolerant cyprinid richness were all significant, with \% invertivore/piscivore minus creek chubs being the only positive relationship (Figure 2). Percent EPT, fish abundance, and total fish biomass were all significantly correlated with drainage area, with \%EPT being the only significant negatively correlated variable. 
Habitat has a positive relationship with electrical conductivity in mitigated and control sites and a slightly negative response in reference sites. There was a clear negative relationship for most biotic variables regardless of mitigation with respect to electrical conductivity (Figure 2). Fish diversity had a negative trend with electrical conductivity in mitigated and reference sites; however, a positive trend in the control sites, which seems to be the product of single outlier (Figure 2). Percent cyprinids had a positive response to electrical conductivity in control and reference sites but no trends with in mitigation sites. Mitigation sites were slightly higher than the control and reference sites for most response variables, which is consistent with the results from Table 1. Habitat was negatively correlated with mitigated and control sites with respect to drainage area. Fish metrics had a positive response to drainage area in all metrics except \% cyprinids and $\%$ tolerant species (Figure 3). Mitigation sites were measurably higher than control sites for all variables; however, they were still below reference conditions for many variables (Figure 3).

We found few consistent patterns given AIC results (Table 2). Drainage area was the top competing model for abundance (AICc weight=0.84), game fish abundance (AICc weight $=0.53$ ), and total biomass (AICc weight $=0.86$ ). Additionally, drainage area was highly correlated to these variables as well with $R^{2}$ values of $0.47,0.56$, and 0.61 respectively. The null model, or just using the average of the data, was found to be the top competing model for seven of the eleven variables. Development condition score was found to be the best model for predicting habitat (AICc weight $=0.4$ ); however, with a low $R^{2}$ of 0.28 . We observed a similar pattern for fish diversity and $\%$ cyprinid with 
respect to development condition; it was the second competing model behind the null but a weak correlation $\left(R^{2}=0.187,0.09\right)$. Aside from game fish abundance and total biomass the interactive models added little to the cumulative weight of the models. Drainage area $\mathrm{x}$ electrical conductivity interaction was the second competing model for both game fish abundance and total biomass with AICc weights of 0.45 and 0.13 respectively.

ANCOVA showed that stream type (mitigated vs. control vs. reference) was statistically significant in many of the response variables (Table 3). When adjusting for drainage area, \% tolerant, cyprinid richness, tolerant cyprinid richness, and tolerant species richness were all significantly different with respect to stream type and \% tolerant species had a electrical conductivity response as well $(p=0.0282)$. Ephermeroptera richness was the only macroinvertebrate response variable that had significant site type effect. Ephermeroptera richness did not have a electrical conductivity or drainage area covariate effect. Additionally, there were no unadjusted fish metrics that had a electrical conductivity effect; however, there were five response variables that had a drainage effect (Table 3). Total fish biomass, fish diversity, and game fish abundance had significant stream type effects and drainage area effects. Whereas invertivore richness and cyprinid richness w/o blacknose dace and creek chubs had a drainage area effect but no type effect. Interestingly, total fish biomass and game fish abundance had a type and drainage area interaction effect (Table 3). 
The average expected increase with mitigation exceeded control in 24 of the 26 metrics (Figure 4). Trichoptera and shredder richness were the only variables whose mitigated means did not exceed the controls (Figure 4). There are clear expectations of increase with mitigation and they support that of Table 1. On average total biomass is expected to have the largest increase from control and although many of the variables were not statistically different, there is a measurable difference between mitigated and control reaches (Table 1, Figure 4).

\section{Discussion}

Off-site NCD structures are the predominant form of mitigation in the coalfields of West Virginia. Regardless of the landscape and possible stressors, the restoration technique selected seems to always be in-stream hard engineered structures (i.e. cross vanes) in Southern West Virginia. This practice has changed slightly with the addition of toe wood, riparian planting, and reconnecting of the floodplain. These projects, however, are still scarce and have only begun installation recently.

There seems to be little concern to where mitigation is placed. Our sites ranged from $2.7 \mathrm{~km}^{2}-221 \mathrm{~km}^{2}$ in size and we were a part of a project that exceeds $1000 \mathrm{~km}^{2}$ in size. Mitigated sites ranged from the outflow of settling ponds just beneath mine boundaries, to highly developed areas within towns, to highly forested areas. We believe these size and location differences led to the high variability in stream responses.

Not surprisingly, habitat quality was consistently higher at mitigated sites compared to control sites. These structures are designed to physically manipulate the stream and 
appear to be successfully doing so. Our results add to a growing body of literature that indicates that standard stream restoration practices are nearly always successful in improving physical habitat conditions (Whiteway et al. 2010, Nilsson et al. 2014). For example, Whiteway et al. (2010), through a meta-analysis of published assessments, found that all of the 51 reports investigated had a positive change on pool size and depth due to mitigation (Whiteway et al. 2010). Similaraly, Levell and Chang (2008) found that pools were created and remained at equilibrium in a restored reach of river. However, they also observed that the mean particle size in the restored reach decreased and may lead to aggradation (Levell and Chang 2008). Other studies have shown that improvements to habitat do not always persist. Champoux et al. (2003) found that a restoration project in the 1960 s increased in pool area from $267 \mathrm{~m}^{2}$ to 625 $\mathrm{m}^{2}$ after restoration, but has since decreased to $488 \mathrm{~m}^{2}$. Miller et al. (2015, chapter 1 ) has shown that structures show evidence of filling in on a large West Virginia river. There are not many long term studies on in-stream structures, so the true success expectancies of them are unknown and probably dependent on many factors (i.e. materials used, installation practices, stream flow, gradient, maintenance ).

We found little evidence of macroinvertebrate response with stream restoration activities. Similarly Palmer et al. (2010) found in a comprehensive study that only 2 of 78 projects found a statistically significant increase in macroinvertebrate diversity. Also, Dolph et al. (2015) found little difference between restored and unrestored reaches of a stream with respect to macroinvertebrates. However there have been studies that do find significant effects on macroinvertebrates with restoration activities (Mueller et al. 
2014, Rios-Touma et al. 2014, and McDermond-Spies et al. 2014). We found no difference between any invertebrate metrics among mitigated portions and control reaches; however, ANCOVA did show that there was a slight mitigation effect with respect to mayflies.

We believe there are at least three reasons why a positive macroinvertebrate response to mitigation was not observed. One reason is that macroinvertebrate assemblages in this region are strongly controlled by water quality rather than physical habitat (Hartman et al. 2005, Merovich et al. 2010, Petty et al. 2010, and Merriam et al. 2015). The mitigation projects that we studied address physical habitat only, not water chemistry. Therefore, improved habitat is of limited value in streams with poor water quality. Violin et al. (2011) studied the effects of urban stream restoration and compared sites to unrestored and forested reference sites. They found that the restored sites were chemically constrained and observed no differences between restored and unrestored urban streams. Furthermore, both restored and unrestored urban sites were significantly dissimilar to forested sites with respect to macroinvertebrates (Violin et al. 2011).

A second explanation is that we saw little change in macroinvertebrates due to saturation of tolerant species in the reaches. Similarly, Friberg et al. (2014) saw little change in a restored Danish stream because the macroinvertebrates found there had such a high species pool presence they essentially left no space for new colonizers; the stream had reached a macroinvertebrate carrying capacity. The constraints of the 
landscape could limit the availability of intolerant to colonize a new suitable area. Kitto et al. (2015) argue that focusing on local conditions and disregarding its spatial location will lead to low dispersal of invertebrates. They found that a streams' spatial location was a better predictor for success than its' local environmental conditions (Kitto et al. 2015). Therefore, many of our sites would not see a positive shift in invertebrates due to the poor condition of the neighboring streams and would just increase in the already present species. Surprisingly, we did not find a significantly negative correlation between ephermeroptera richness and electrical conductivity as we would have hypothesized (Pond 2010, Gangloff et al. 2014). The third possibility is that macroinvertebrates have a slow recovery and we may be too early to assess any positive changes (Muotka et al. 2012).

Comparisons between mitigated and control reaches revealed that fish responses to restoration were highly variable, which is consistent with many restoration projects (Pretty et al. 2003, Baldigo et al. 2008, and Baldigo and Warren 2008). The observed increase in gamefish abundance was driven by two sites, Paint Creek and West Fork of Pond Fork. Seven of our sites had zero game fish in either reach and three of the sites were only $+/$ - two fish in game fish abundance. Gilbert Creek had an average difference of +15 game fish for the mitigated reach, but Paint Creek had an average of +49 fish for mitigation, and West Fork of Pond Fork had an average of +43 game fish in the mitigated reach. 
Changes in fish abundance, average total biomass, $\%$ cyprinid, and \% tolerant species, all suggest that the increase in biomass and abundance was driven almost entirely by black nose dace and creek chubs, two highly tolerant, mobile cyprinids. Change in \% cyprinids was not significant when blacknose dace and creek chubs were removed. This suggests that the increase in the other metrics is due to the increase in tolerant taxa.

Contrary to those results, a difference in cyprinid richness, tolerant cyprinid richness and cyprinid richness minus blacknose dace and creek chubs, suggests different minnows are colonizing the mitigated area. Investigating the data reveals that this difference is driven by two sites. Comparing the differences between mitigated and control sites with respect to cyprinid richness, 12 sites ranged from 0-1.3 (7 of those difference are between 0-0.33); were Gilbert Creek and Pond Fork differences +3.3 and +4 , respectively. Gilbert Creek had rosyside daces (Clinostomus funduloides), spotfin shiners (Cyprinella spiloptera), and striped shiners (Luxilus chrysocephalus) that were not present in the control reach. Pond Fork had silverjaw minnows (Notropis buccatus), rosyface shiners (Notropis rubellus), and mimic shiners (Notropis volucellus) that were not present in its control reach. However, neither site exceeded 8 individuals of any species, making up less than $6 \%$ of their fish assemblage. This suggests that our results are misleading in the fact that large game fish are attracted to these structures, when, in fact, many small tolerant blacknose dace and creek chubs are the first to colonize the area. Rouch (2014) found that in three, $4^{\text {th }}$ order streams in Southern West Virginia, creek chubs made up 84,74 , and $65 \%$ of fishes in the stream. 
When adding blacknose dace, they explained $\sim 90 \%$ of the fish assemblage in all three streams (Rouch 2014). It appears these structures are attracting tolerant fish, which are extremely abundant to the region.

The need for large reference sites is apparent because many of reference trend lines make abrupt changes that are not indicative of the mitigated and control trends (Figure 3). Our mitigated sites ranged from $2.7 \mathrm{~km}^{2}-221 \mathrm{~km}^{2}$ where our reference sites ranged from only $1.2 \mathrm{~km}^{2}-23.4 \mathrm{~km}^{2}$. Nevertheless, drainage area seems to be one of the major drivers behind our results. Drainage area positively correlated with two fish variables (abundance and total biomass) and negatively with one macroinvertebrate variable (ephermeroptera richness). Drainage area was found to be a competing model in four of the ten fish metrics and highly correlated to those response variables. Also, drainage area was found to have a covariate effect with five of the eleven variables. This just reiterates the fact that many responses are driven by the size of the stream. All fish metrics except for \% tolerant species, \% cyprinids, and \% tolerant cyprinid richness were strongly positively correlated with drainage area, especially in mitigated sites (Figure 3). It is intuitive that when drainage area is increased there should be more fish $\left(R^{2}=0.613\right) ;$ and if that site is restored given the right context we would expect a measurable increase in fish metrics.

According to AIC results there is no clear predictor for fish and habitat responses. The null model was the top competing model for seven of the eleven response variables and the second competing model for two more variables. If the mean of the data is the best 
predictor for these response variables, it would indicate that there are other factors driving fish responses. Mining and development conditions are neighborhood conditions of the HUC 12 watershed each site is within, which we hypothesized would be a predictor for our response variables. This is an intensively mined area of central Appalachia and mining condition was a top competing model for six of the eleven response variables. However, the most variance explained by mining condition is habitat, and is only $17 \%$. Although it was a top competing model it was weak as an explanatory variable. Merriam et al. (2011) found strong correlations between mining and residential development and the additive effect of them on macroinvertebrate indices in southern West Virginia. Similarly, Lindberg et al. (2011) found that fish abundances and health are compromised with the increase of coal mining in the Mud River, WV. We know mining and development negatively effects aquatic biota and we didn't detect a clear neighborhood signal; therefore local landuse must play a larger role than that of the neighborhood. Drainage area was a top competing model for some fish response variables, but was still not as good as the null model. However, it was positively correlated with most fish metrics.

Our results support the hypothesis that mitigation success is driven by a complex relationship between local and regional factors. We found that physical habitat is always increased with mitigation; however persistence of these benefits is unknown. Our results, as well as the body of literature, suggest that mitigation has little or no positive effect on macroinvertebrates. The rigid chemical tolerance of macroinvertebrates seems that regardless of physical changes to the stream 
macroinvertebrates will not use these new habitats. We found that restoration predominately, in the coalfields of West Virginia, attracts tolerant, abundant blacknose dace and creek chubs, which does not fundamentally improve the biological condition of the mitigated streams. Gilbert Creek, Paint Creek, and West Fork of Pond Fork were considerably higher in fish and macroinvertebrates metrics, but were overshadowed by the high number of poor sites. This suggests to us that within the right local and regional context, stream restoration can have statistical improvements. 


\section{Literature Cited}

Al-Chokhachy, R., B.B. Roper, and E.K. Archer. 2010. Evaluating the status and trends of physical stream habitat in headwater streams within the interior Columbia River and upper Missouri River basins using an index approach. Transactions of the American Fisheries Society. 139(4):1041-1059..

Arango, C. P. P.W. James, and K.B. Hatch. 2015. Rapid ecosystem response to restoration in an urban stream. Hydrobiologia, 749(1):197-211.

Baldigo, B. P., D.R. Warren, A.G. Ernst, and C.I. Mulvihill. 2008. Response of fish populations to natural channel design restoration in streams of the Catskill Mountains, New York. North American Journal of Fisheries Management, 28(3):954-969.

Baldigo, B. P. and D.R. Warren. 2008. Detecting the response of fish assemblages to stream restoration: effects of different sampling designs. North American Journal of Fisheries Management, 28(3): 919-934.

Bernhardt, E. S., M. Palmer, J.D. Allan, G. Alexander, K. Barnas, S. Brooks, S... and E. Sudduth. 2005. Synthesizing U. S. river restoration efforts. Science(Washington), 308(5722):636-637.

Bernhardt, E. S., B.D. Lutz, R.S. King, J.P. Fay, C.E. Carter, A.M. Helton, and J. Amos. 2012. How many mountains can we mine? Assessing the regional degradation of central Appalachian rivers by surface coal mining. Environmental science \& technology, 46(15): 8115-8122.

Bryant, M.D.,J.P. Caouette, and B.E. Wright. 2004. Evaluating stream habitat survey data and statistical power using an example from southeast Alaska. North American Journal of Fisheries Management. 24: 1353- 1362.

Dolédec, S., M. Forcellini, J.M. Olivier, and N. Roset. 2015. Effects of large river restoration on currently used bioindicators and alternative metrics. Freshwater Biology, 60(6), 1221-1236.

Dolph, C. L., S.L. Eggert, J. Magner, L.C. Ferrington Jr, and B. Vondracek. 2015. Reach-scale stream restoration in agricultural streams of southern Minnesota alters structural and functional responses of macroinvertebrates. Freshwater Science, 34(2): 535-546.

Edwards, C.J., B. L. Griswold, R. A. Tubb, E. C. Weber, and L.C. Woods. 1984. Mitigating effects of artificial riffles and pools on the fauna of a channelized warmwater stream. North American Journal of Fisheries Management 4:194-203.

Friberg, N., A. Baattrup-Pedersen, E.A. Kristensen, B. Kronvang, S.E. Larsen, M.L. Pedersen, and P. Wiberg-Larsen. 2014. The River Gelså restoration revisited: Habitat 
specific assemblages and persistence of the macroinvertebrate community over an 11year period. Ecological Engineering, 66:150-157.

Gangloff, M. M., M. Perkins, P.W. Blum, and C. Walker. 2015. Effects of Coal Mining, Forestry, and Road Construction on Southern Appalachian Stream Invertebrates and Habitats. Environmental management, 55(3):702-714.

Gellert, G., S. Behrens, and M. Raschke. 2012. The return of degraded stream ecosystems by using positive impacts from near-natural sections: a new practical guide for restorations. Water and Environment Journal, 26(3): 415-421.

Gerritsen, J., J. Burton, and M.T. Barbour. 2000. A stream condition index for West Virginia wadeable streamsThe University of Chicago PressOwings Mills. Maryland (Available from: http://www. dep. wv.gov/WWE/watershed/bio_fish/Documents/WVSCl. pdf).

Harrison S.S.C., J.L. Pretty, D. Shepherd, A.G. Hildrew, C. Smith, and R.D. Hey. 2004. The effect of instream rehabilitation structures on macroinvertebrates in lowland rivers. The Journal of Applied Ecology, 41:1140-1154.

Hartman, K. J., M.D. Kaller, J.W. Howell, and J.A. Sweka. 2005. How much do valley fills influence headwater streams?. Hydrobiologia, 532(1-3): 91-102.

Haase, P., D. Hering, S.C. Jähnig, A.W. Lorenz and A. Sundermann. 2013. The impact of hydromorphological restoration on river ecological status: a comparison of fish, benthic invertebrates, and macrophytes. Hydrobiologia, 704(1):475-488.

Heald, C. L. and D.V Spracklen. 2015. Land Use Change Impacts on Air Quality and Climate. Chemical reviews.

Kauffman, J. B., R.L. Beschta, N. Otting, N., and D. Lytjen. 1997. An ecological perspective of riparian and stream restoration in the western United States. Fisheries, 22(5):12-24.

Kitto, J. A., D.P. Gray, H.S. Greig,D.K. Niyogi, and J.S. Harding. 2015. Metacommunity theory and stream restoration: evidence that spatial position constrains stream invertebrate communities in a mine impacted landscape. Restoration Ecology, 23(3):284-291.

Kuchapski, K. A. and J.B. Rasmussen. 2015. Surface coal mining influences on macroinvertebrate assemblages in streams of the Canadian Rocky Mountains. Environmental Toxicology and Chemistry.

Lindberg, T. T., E.S. Bernhardt, R. Bier, A.M. Helton, R.B. Merola, A. Vengosh, and R.T. Di Giulio. 2011. Cumulative impacts of mountaintop mining on an Appalachian watershed. Proceedings of the National Academy of Sciences, 108(52):20929-20934. 
Lorenz, A. W. and C.K. Feld. 2013. Upstream river morphology and riparian land use overrule local restoration effects on ecological status assessment. Hydrobiologia, 704(1):489-501.

Lund, J.A. 1976. Evaluation of channelization and mitigation on the fishery resources of the St. Regis River, Montana.Fish and Wildlife Service, USDI.FWS/OBS76/06.Washington, D.C.

McDermond-Spies, N., D. Broman, A. Brantner, A., and K. Larsen. 2014. FamilyLevel Benthic Macroinvertebrate Communities Indicate Successful Relocation and Restoration of a Northeast lowa Stream. Ecological Restoration, 32(2):161-170.

Merriam, E. R., J.T. Petty, G.T. Merovich Jr, J.B. Fulton, and M.P. Strager. 2011. Additive effects of mining and residential development on stream conditions in a central Appalachian watershed. Journal of the North American Benthological Society, 30(2): 399-418.

Merritt, R. W., and K. W. Cummins. 2008. An introduction to the aquatic insects of North America, Fourth edition. Kendall/Hunt Publishing Co., Dubuque, IA.

Miller, E. M. 2011. Master's Thesis. Ecological Benefits of Mitigation on a Large River Mainstem in an Intensively Mined Appalachian Watershed. West Virginia University.

Miller, S. W., P. Budy, and J.C. Schmidt. 2010. Quantifying Macroinvertebrate Responses to In-Stream Habitat Restoration: Applications of Meta-Analysis to River Restoration. Restoration Ecology 18:8-19.

Mitchell, John. 2006. When Mountains Move. National Geographic.

Mueller, M., J. Pander,and J. Geist. 2014. The ecological value of stream restoration measures: an evaluation on ecosystem and target species scales. Ecological Engineering, 62:129-139.

Muotka, T., R. Paavola, A. Haapala, M. Novikmec, and P. Laasonen. 2002. Longterm recovery of stream habitat structure and benthic invertebrate communities from instream restoration. Biological Conservation 105:243-253.

Nilsson, C., L.E. Polvi, J. Gardeström,E.M. Hasselquist, L. Lind,and J.M. Sarneel. 2014. Riparian and in-stream restoration of boreal streams and rivers: success or failure?. Ecohydrology.

Palmer, M.A., R. Ambrose, and N.L. Poff.1997.Ecological theory and community restoration ecology. Journal of Restoration Ecology 5: 291-300. 
Palmer, M.A., H.L. Menninger, and E.S. Bernhardt. 2010. River restoration, habitat heterogeneity and biodiversity: a failure of theory or practice? Freshwater Biology 55(1): 205-222.

Peckarsky, B. L., P. R. Fraissinet, M. A. Penton, and J. Conklin, D. J. 1990. Freshwater macroinvertebrates of Northeastern North America.CornellUniversity Press, Ithaca.

Poff ,N.L., J.D. Allan, M.B. Bain, J.R. Karr, K.L. Prestegaard, B.D. Richter, R.E. Sparks and J.C. Stromberg. 1997. The natural flow regime: a paradigm for river conservation and restoration. BioScience,47:769-784.

Polivka, K. M., E.A. Steel, and J.L. Novak. 2014. Juvenile salmon and steelhead occupancy of stream pools treated and not treated with restoration structures, Entiat River, Washington. Canadian Journal of Fisheries and Aquatic Sciences, 72(999): 1-9.

Pond, G. J. 2010. Patterns of Ephemeroptera taxa loss in Appalachian headwater streams (Kentucky, USA). Hydrobiologia, 641(1): 185-201.

Pond, G. J., J.E. Bailey, and B. Lowman. 2008. West Virginia GLIMPSS (genus-level index of most probable stream status): A benthic macroinvertebrate index of biotic integrity for West Virginia's wadeable streams. West Virginia Department of Environmental Protection, Division of Water and Waste Management, Watershed Branch, Charleston, WV, USA.

Pretty, J. L., S.S.C. Harrison, D.J. Shepherd, C. Smith, A.G. Hildrew,and R.D. Hey. 2003. River rehabilitation and fish populations: assessing the benefit of instream structures. Journal of Applied Ecology, 40(2):251-265.

Rios-Touma, B., C. Prescott, S. Axtell, and G.M. Kondolf. 2014. Habitat Restoration in the Contest of Watershed Prioritization: The Ecological Performance of Urban Stream Restoration Projects in Portland, Oregon. River Research and Applications.

Roni, P., K. Hanson, and T. Beechie. 2008. Global review of the physical and biological effectiveness of stream rehabilitation techniques. North American Journal of Fish Managent.28: 856-890.

Roni, P.,T.J. Beechie, G.R. Pess, and K.M. Hanson. 2014. Wood Placement in River Restoration: Fact, Fiction and Future Direction. Canadian Journal of Fisheries and Aquatic Sciences, 72(3): 466-478.

Rouch , Mathew. 2014. Master's Thesis. "Mining" for a Reference Condition in Southern West Virginia Streams. Virginia Commonwealth University.

Shank, M. Trends in Mining Fills and Associated Stream Loss in West Virginia, 1984-2009. West Virginia Department of Environ-mental Protection: 2010. 
Stranko, S. A., R.H. Hilderbrand, and M.A. Palmer. 2012. Comparing the fish and benthic macroinvertebrate diversity of restored urban streams to reference streams. Restoration Ecology, 20(6):747-755.

Thompson, D. M. and G.N. Stull. 2002. The development and historic use of habitat structures in channel restoration in the United States: the grand experiment in fisheries management. Géographie physique et Quaternaire, 56(1): 45-60.

Violin, C. R., P. Cada, E.B. Sudduth, B.A. Hassett, D.L. Penrose, and E.S. Bernhardt. 2011. Effects of urbanization and urban stream restoration on the physical and biological structure of stream ecosystems. Ecological Applications, 21(6), 19321949.

Whiteway, S.L., P.M. Biron, A. Zimmermann, O. Venter, and J.W.A Grant. 2010.Do in-stream restoration structures enhance salmonid abundance? A meta-analysis. Can. J. Fish. Aquat. Sci.67(5): 831-841. doi:10.1139/F10-021

WVDEP (West Virginia Department of Environmental Protection). 2009. Standard operating procedures. West Virginia Department of Environmental Protection, Charleston, West Virginia. 


\section{Tables and Figures}
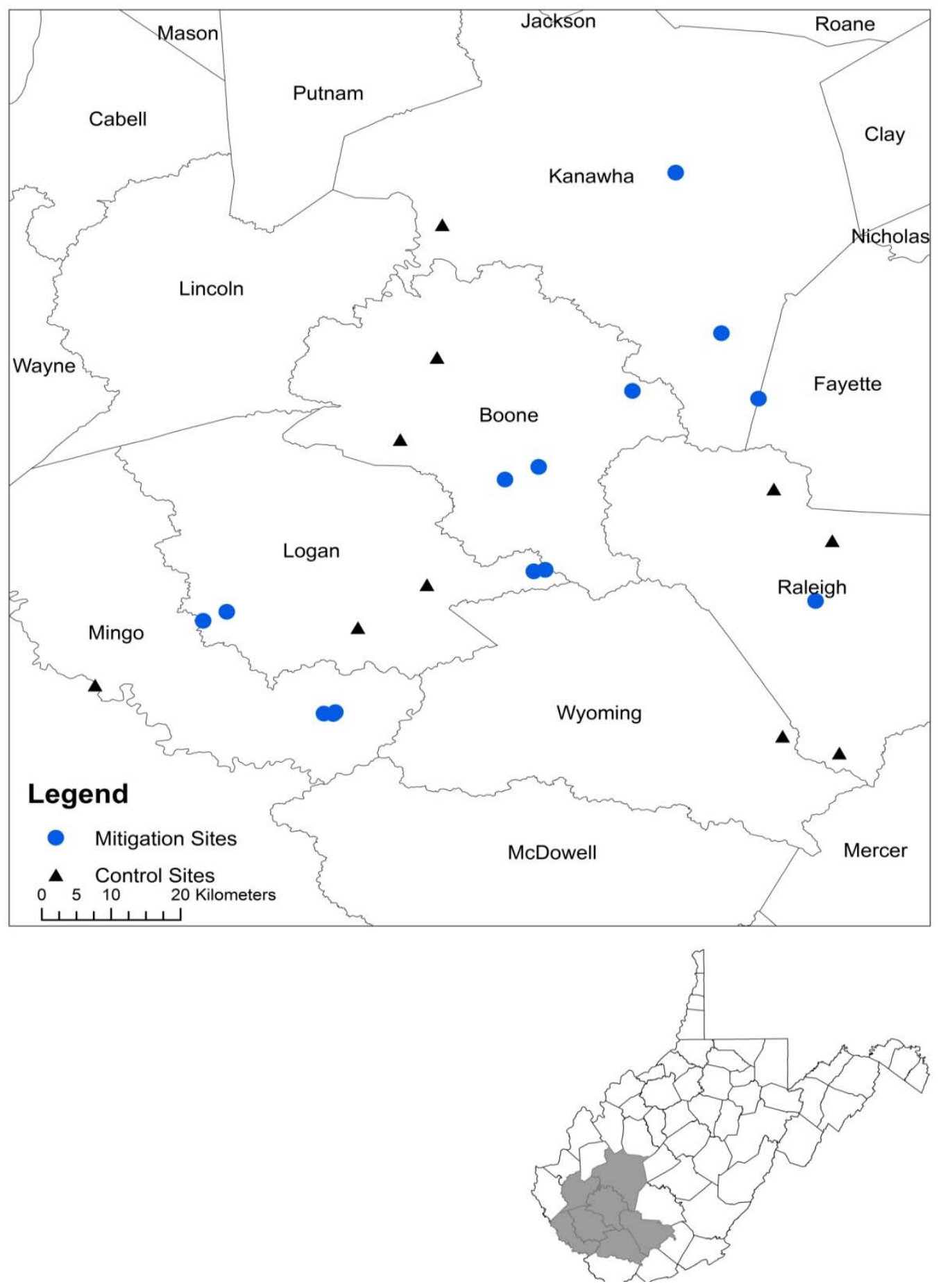

Figure 1. Map of study area. 
Table 1. Mann- Whitney $U$ test results of macroinvertebrate, habitat, and fish variables. Also correlations between variables and electrical conductivity (Cond) and drainage area (DA). Significant values are bolded.

\begin{tabular}{|c|c|c|c|c|c|c|c|}
\hline & & & & & U-test & Cond & DA \\
\hline & Variable & Type & Range & Mean(SE) & P-Value & R-stat/P-Value & R-stat/P-Value \\
\hline \multirow[t]{34}{*}{ Fish } & Diversity & Mitigated & $0.39-2.05$ & $1.34(0.16)$ & 0.042 & $0.334 / 0.243$ & $-0.323 / 0.259$ \\
\hline & & Control & $0-2.2$ & $1.08(0.17)$ & & & \\
\hline & Abundance & Mitigated & $16-1077$ & $244(90)$ & 0.092 & $0.349 / 0.22$ & $0.692 / 0.006$ \\
\hline & & Control & $11-966$ & $166(82)$ & & & \\
\hline & Game Fish Abundance & Mitigated & $0-109$ & 18.19(8.99) & 0.03461 & $-0.056 / 0.848$ & $-0.071 / 0.811$ \\
\hline & & Control & $0-70$ & $16.55(7.84)$ & & & \\
\hline & Average Total Biomass (g) & Mitigated & $93-29763$ & $6680(2999)$ & 0.0012 & $-0.148 / 0.613$ & $0.782 / 0.0009$ \\
\hline & & Control & $18-12890$ & 3199(1445) & & & \\
\hline & Average Fish Biomass (g) & Mitigated & $3.1-200$ & $29.9(14.8)$ & 0.946 & $0.266 / 0.358$ & $-0.069 / 0.813$ \\
\hline & & Control & $1.2-116$ & $27.6(10.2)$ & & & \\
\hline & \% Cyprinid & Mitigated & $10-100$ & 75(7.9) & 0.0503 & $-0.208 / 0.475$ & $-0.144 / 0.621$ \\
\hline & & Control & $0-100$ & $54(11.3)$ & & & \\
\hline & \% lithophilic Spawners & Mitigated & $0-85$ & $34(8.6)$ & 0.1955 & $0.401 / 0.155$ & $-0.07 / 0.81$ \\
\hline & & Control & $0-75$ & $27(7.5)$ & & & \\
\hline & $\%$ invertivores & Mitigated & $0-80$ & $25(6.7)$ & 0.4561 & $0.339 / 0.235$ & $-0.303 / 0.292$ \\
\hline & & Control & $0-83$ & $21(7.5)$ & & & \\
\hline & $\%$ tolerant Species & Mitigated & $43-100$ & $79(5.7)$ & 0.0546 & $-0.265 / 0.359$ & $-0.065 / 0.825$ \\
\hline & & Control & $0-100$ & $58(10.4)$ & & & \\
\hline & \% Cyprinids - BND and SEAT & Mitigated & $0-80$ & $24(7.8)$ & 0.23 & $0.241 / 0.406$ & $0.1942 / 0.506$ \\
\hline & & Control & $0-100$ & $23(7.6)$ & & & \\
\hline & $\%$ invertevores/piscivore -SEAT & Mitigated & $0-96$ & $33(9.0)$ & 0.906 & $0.487 / 0.077$ & $0.349 /-0.271$ \\
\hline & & Control & $0-92$ & $28(8.9)$ & & & \\
\hline & Tolerant Richness & Mitigated & $0.3-9$ & $3.9(0.71)$ & 0.177 & $-0.467 / 0.092$ & $0.04 / 0.891$ \\
\hline & & Control & 0-7 & $3.1(0.61)$ & & & \\
\hline & Cyprinid Richness & Mitigated & $0.3-7.6$ & $3.5(0.56)$ & 0.06505 & $-0.485 / 0.078$ & $0.075 / 0.799$ \\
\hline & & Control & $0-6$ & $2.4(0.46)$ & & & \\
\hline & Tolerant Cyprinid Richness & Mitigated & $0.3-6$ & $2.5(0.4)$ & 0.08061 & $-0.629 / 0.016$ & $0.176 / 0.547$ \\
\hline & & Control & $0-4.3$ & $1.7(0.32)$ & & & \\
\hline & Cyprinid Richness - BND \& SEAT & Mitigated & $0-6$ & $2.2(0.59)$ & 0.05248 & $-0.284 / 0.324$ & $0.2157 / 0.459$ \\
\hline & & Control & $0-6$ & $1.3(0.42)$ & & & \\
\hline & Richness of Lithophilic Spawners & Mitigated & $0-6.5$ & $2.4(0.62)$ & 0.1358 & $-0.298 / 0.30$ & $-0.024 / 0.935$ \\
\hline & & Control & $0-7$ & $1.9(0.57)$ & & & \\
\hline & Invertivore Richness & Mitigated & $0-13$ & $3.3(1.1)$ & 0.05443 & $-0.292 / 0.311$ & $0.286 / 0.322$ \\
\hline & & Control & $0-12.5$ & $2.3(0.92)$ & & & \\
\hline \multirow[t]{16}{*}{ Macroinvertebrate } & WVSCl & Mitigated & $30.5-68.0$ & $51.5(3.3)$ & 0.2261 & $-0.353 / 0.236$ & $-0.424 / 0.149$ \\
\hline & & Control & $27.9-62.0$ & $48.3(3.2)$ & & & \\
\hline & \%EPT & Mitigated & $4.4-82.3$ & $44.3(6.4)$ & 0.7334 & $-0.223 / 0.463$ & $-0.511 / 0.073$ \\
\hline & & Control & $13.2-63.7$ & $40.5(5.3)$ & & & \\
\hline & GLIMPSS & Mitigated & $9.4-38.7$ & $24.7(2.8)$ & 0.191 & $0.026 / 0.932$ & $-0.223 / 0.464$ \\
\hline & & Control & $7.3-41-0$ & $18.3(3.5)$ & & & \\
\hline & E Richness & Mitigated & $0-5$ & $1.8(0.44)$ & 0.4395 & $-0.472 / 0.104$ & $0.337 / 0.26$ \\
\hline & & Control & $0-3$ & $1.2(0.24)$ & & & \\
\hline & P Richness & Mitigated & $0-4$ & $1.8(0.34)$ & 0.1587 & $-0.148 / 0.628$ & $-0.43 / 0.142$ \\
\hline & & Control & $0-3$ & $1.2(0.3)$ & & & \\
\hline & T Richness & Mitigated & $1-5$ & $3.0(0.34)$ & 0.9584 & $0.0953 / 0.757$ & $-0.20 / 0.511$ \\
\hline & & Control & $0-6$ & $3.1(0.57)$ & & & \\
\hline & Shredder Richness & Mitigated & $0-2$ & $0.69(0.21)$ & 0.9331 & $0.433 / 0.139$ & $-0.148 / 0.631$ \\
\hline & & Control & $0-2$ & $0.69(0.24)$ & & & \\
\hline & Genus Richness & Mitigated & $6-20$ & $13.5(1.24)$ & 0.3257 & $0.191 / 0.532$ & $-0.152 / 0.621$ \\
\hline & & Control & $2-20$ & $11(1.67)$ & & & \\
\hline \multirow[t]{2}{*}{ Habitat } & RVHA & Mitigated & $105-168$ & $148(4.8)$ & 0.005 & $0.332 / 0.268$ & $-0.103 / 0.737$ \\
\hline & & Control & 77-165 & $128(6.5)$ & & & \\
\hline
\end{tabular}


Table 2. AIC results using only variables that were significantly different in pairwise comparisons (Table 1). Null=Data mean, DA=Drainage Area, Cond= Electrical Conductivity, development condition and mining condition=HUC 12 neighborhood condition scores, cyp=Cyprinid, BND=Blacknose Dace, and SEAT $=$ Creek Chub.

\begin{tabular}{|c|c|c|c|c|c|c|}
\hline Variable & Model & $\mathrm{AlCc}$ & Delta_AICc & AICc.Wt & Cum.wt & $\mathrm{R}^{2}$ \\
\hline \multirow{8}{*}{ Diversity } & Null & 19.14 & 0 & 0.29 & 0.29 & \\
\hline & Development & 19.54 & 0.4 & 0.23 & 0.52 & 0.187 \\
\hline & Swim Distance & 20.19 & 1.05 & 0.17 & 0.69 & 0.149 \\
\hline & Conductivity & 20.79 & 1.65 & 0.13 & 0.82 & 0.112 \\
\hline & Drainage Area & 20.9 & 1.76 & 0.12 & 0.94 & 0.104 \\
\hline & Mining & 22.44 & 3.3 & 0.05 & 0.99 & 0.000 \\
\hline & Mining*Development & 26.42 & 7.28 & 0.01 & 1 & 0.307 \\
\hline & $\mathrm{DA}^{*}$ Cond & 28.72 & 9.58 & 0 & 1 & 0.183 \\
\hline \multirow[t]{8}{*}{ Abundance } & Drainage Area & 184.04 & 0 & 0.84 & 0.84 & 0.478 \\
\hline & Null & 189.85 & 5.81 & 0.05 & 0.88 & \\
\hline & Development & 190.31 & 6.27 & 0.04 & 0.92 & 0.184 \\
\hline & $\mathrm{DA}^{*}$ Cond & 190.42 & 6.38 & 0.03 & 0.95 & 0.570 \\
\hline & Conductivity & 191.33 & 7.29 & 0.02 & 0.98 & 0.122 \\
\hline & Mining & 192.36 & 8.32 & 0.01 & 0.99 & 0.055 \\
\hline & Swim Distance & 193.11 & 9.06 & 0.01 & 1 & 0.004 \\
\hline & Mining*Development & 195.57 & 11.53 & 0 & 1 & 0.380 \\
\hline \multirow[t]{8}{*}{ Game Fish Abundance } & Drainage Area & 113.83 & 0 & 0.53 & 0.53 & 0.556 \\
\hline & DA*Cond & 114.17 & 0.34 & 0.45 & 0.98 & 0.762 \\
\hline & Null & 121.89 & 8.05 & 0.01 & 0.99 & \\
\hline & Swim Distance & 122.72 & 8.89 & 0.01 & 0.99 & 0.162 \\
\hline & Conductivity & 124.71 & 10.88 & 0 & 1 & 0.034 \\
\hline & Development & 125 & 11.16 & 0 & 1 & 0.013 \\
\hline & Mining & 125 & 11.17 & 0 & 1 & 0.014 \\
\hline & Mining*Development & 133.62 & 19.79 & 0 & 1 & 0.047 \\
\hline \multirow[t]{8}{*}{ Total Biomass } & Drainage Area & 276.27 & 0 & 0.86 & 0.86 & 0.613 \\
\hline & DA*Cond & 280.04 & 3.78 & 0.13 & 0.99 & 0.735 \\
\hline & Null & 286.23 & 9.96 & 0.01 & 0.99 & \\
\hline & Swim Distance & 287.32 & 11.05 & 0 & 1 & 0.147 \\
\hline & Development & 288.67 & 12.4 & 0 & 1 & 0.060 \\
\hline & Conductivity & 289.23 & 12.96 & 0 & 1 & 0.022 \\
\hline & Mining & 289.35 & 13.09 & 0 & 1 & 0.013 \\
\hline & Mining*Development & 296.69 & 20.42 & 0 & 1 & 0.130 \\
\hline \multirow[t]{8}{*}{ \% Cyprinid } & Null & 17.02 & 0 & 0.41 & 0.41 & \\
\hline & Development & 19.02 & 1.99 & 0.15 & 0.56 & 0.090 \\
\hline & Mining & 19.12 & 2.1 & 0.14 & 0.7 & 0.083 \\
\hline & Conductivity & 19.5 & 2.47 & 0.12 & 0.82 & 0.058 \\
\hline & Swim Distance & 20.06 & 3.04 & 0.09 & 0.91 & 0.019 \\
\hline & Drainage Area & 20.08 & 3.05 & 0.09 & 1 & 0.018 \\
\hline & Mining*Development & 27.26 & 10.24 & 0 & 1 & 0.144 \\
\hline & $\mathrm{DA}^{*}$ Cond & 28.23 & 11.21 & 0 & 1 & 0.082 \\
\hline \multirow[t]{8}{*}{ \% Tolerant Species } & Null & 15.97 & 0 & 0.44 & 0.44 & \\
\hline & Conductivity & 18.08 & 2.11 & 0.15 & 0.59 & 0.082 \\
\hline & Mining & 18.59 & 2.62 & 0.12 & 0.71 & 0.048 \\
\hline & Development & 18.7 & 2.73 & 0.11 & 0.83 & 0.040 \\
\hline & Drainage Area & 19.23 & 3.27 & 0.09 & 0.91 & 0.003 \\
\hline & Swim Distance & 19.27 & 3.31 & 0.08 & 1 & 0.000 \\
\hline & Mining*Development & 27.04 & 11.07 & 0 & 1 & 0.091 \\
\hline & $\mathrm{DA}^{*}$ Cond & 27.08 & 11.11 & 0 & 1 & 0.088 \\
\hline \multirow[t]{7}{*}{ Cyprinid Richness } & Null & 58.86 & 0 & 0.43 & 0.43 & \\
\hline & Mining & 60.25 & 1.39 & 0.22 & 0.65 & 0.128 \\
\hline & Swim Distance & 62.06 & 3.2 & 0.09 & 0.74 & 0.008 \\
\hline & Conductivity & 62.07 & 3.22 & 0.09 & 0.82 & 0.007 \\
\hline & Drainage Area & 62.08 & 3.22 & 0.09 & 0.91 & 0.006 \\
\hline & Development & 62.1 & 3.24 & 0.09 & 1 & 0.005 \\
\hline & Mining*Development & 68.36 & 9.5 & 0 & 1 & 0.187 \\
\hline
\end{tabular}




\begin{tabular}{|c|c|c|c|c|c|c|}
\hline & DA*Cond & 70.54 & 11.68 & 0 & 1 & 0.051 \\
\hline \multirow[t]{8}{*}{ Tolerant Cyp.Richness } & Null & 51.45 & 0 & 0.48 & 0.48 & \\
\hline & Mining & 54.09 & 2.64 & 0.13 & 0.6 & 0.047 \\
\hline & Drainage Area & 54.29 & 2.83 & 0.12 & 0.72 & 0.033 \\
\hline & Conductivity & 54.7 & 3.24 & 0.09 & 0.81 & 0.005 \\
\hline & Swim Distance & 54.7 & 3.25 & 0.09 & 0.91 & 0.004 \\
\hline & Development & 54.73 & 3.28 & 0.09 & 1 & 0.002 \\
\hline & Mining*Development & 63.15 & 11.7 & 0 & 1 & 0.049 \\
\hline & DA*Cond & 63.22 & 11.77 & 0 & 1 & 0.045 \\
\hline \multicolumn{7}{|l|}{ Cyp. Richness - } \\
\hline \multirow[t]{8}{*}{ BND\&SEAT } & Null & 56.75 & 0 & 0.4 & 0.4 & \\
\hline & Mining & 58.51 & 1.76 & 0.17 & 0.56 & 0.045 \\
\hline & Swim Distance & 58.73 & 1.98 & 0.15 & 0.71 & 0.090 \\
\hline & Drainage Area & 59.41 & 2.66 & 0.11 & 0.82 & 0.045 \\
\hline & Development & 59.7 & 2.95 & 0.09 & 0.91 & 0.025 \\
\hline & Conductivity & 59.91 & 3.16 & 0.08 & 0.99 & 0.011 \\
\hline & Mining*Development & 65.52 & 8.77 & 0 & 1 & 0.229 \\
\hline & DA*Cond & 66.07 & 9.32 & 0 & 1 & 0.198 \\
\hline \multirow[t]{8}{*}{ Insectivore Richness } & Null & 61.74 & 0 & 0.43 & 0.43 & \\
\hline & Drainage Area & 63.88 & 2.14 & 0.15 & 0.58 & 0.080 \\
\hline & Swim Distance & 64.04 & 2.3 & 0.14 & 0.72 & 0.069 \\
\hline & Mining & 64.63 & 2.89 & 0.1 & 0.82 & 0.030 \\
\hline & Development & 64.84 & 3.1 & 0.09 & 0.91 & 0.015 \\
\hline & Conductivity & 65.03 & 3.29 & 0.08 & 1 & 0.001 \\
\hline & DA*Cond & 72.53 & 10.79 & 0 & 1 & 0.109 \\
\hline & Mining*Development & 72.93 & 11.19 & 0 & 1 & 0.083 \\
\hline \multirow[t]{8}{*}{ Habitat } & Development & 128.29 & 0 & 0.4 & 0.4 & 0.275 \\
\hline & Null & 129.48 & 1.19 & 0.22 & 0.62 & \\
\hline & Mining & 130.09 & 1.8 & 0.16 & 0.78 & 0.176 \\
\hline & Conductivity & 131.19 & 2.91 & 0.09 & 0.87 & 0.108 \\
\hline & Swim Distance & 131.53 & 3.24 & 0.08 & 0.95 & 0.086 \\
\hline & Drainage Area & 132.71 & 4.43 & 0.04 & 0.99 & 0.005 \\
\hline & Mining*Development & 136.32 & 8.03 & 0.01 & 1 & 0.328 \\
\hline & DA*Cond & 140.1 & 11.82 & 0 & 1 & 0.120 \\
\hline
\end{tabular}



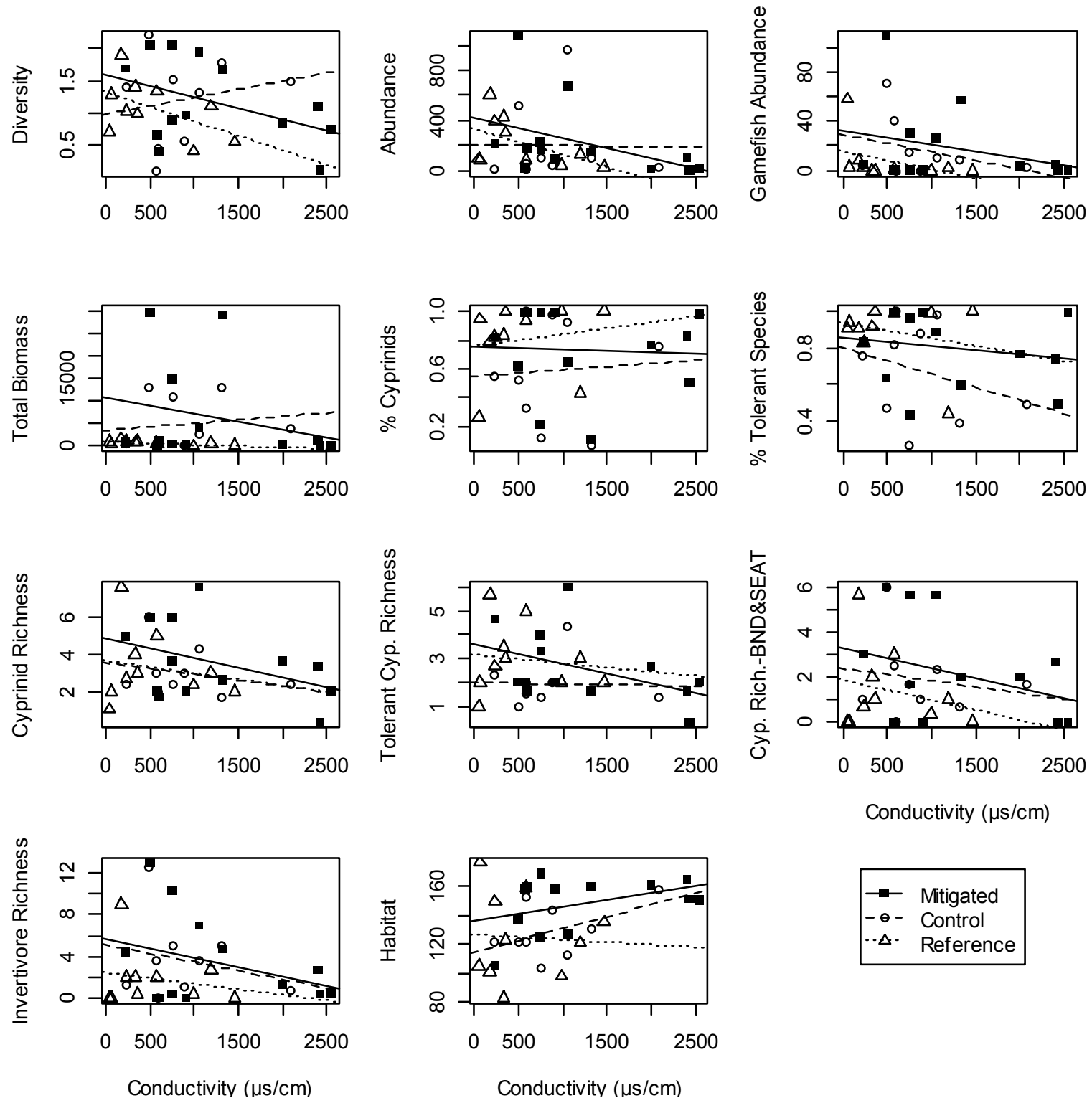

Figure 2. Relationship between site types and significant variables (Table 1) with respect to conductivity. Reference sites included as regional comparisons. 

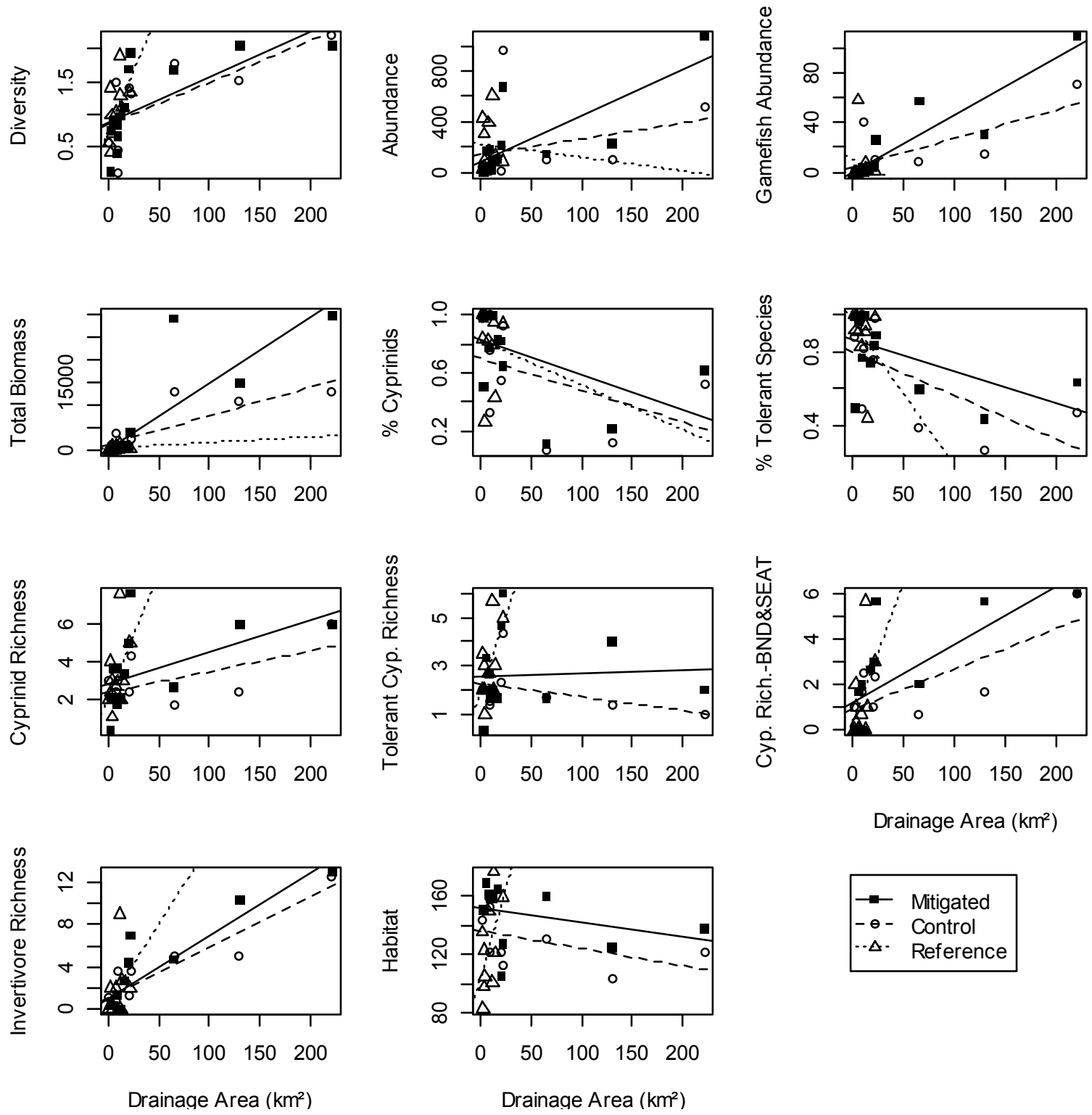

Figure 3. Relationship between site types and significant variables (Table 1) with respect to drainage area. Reference sites included as regional comparisons. 
Table 3. ANCOVA results, only significant variables shown. The first 4 response variables have been adjusted for drainage area, therefore the covariate is conductivity. The second half the covariate is in the response variable column. The + symbol represents significance effects, type effect represent the sites type (i.e. mitigated, control, reference). Cond=Electrical conductivity and DA=Drainage area $\left(\mathrm{km}^{2}\right)$.

\begin{tabular}{|c|c|c|c|c|c|c|c|}
\hline Response Variable & DF & $\mathrm{F}$ & $\mathrm{R}^{2}$ & P-Value & Type effect & Covariate effect & Interaction effect \\
\hline \% Tolerant Species & 5,27 & 2.999 & 0.2372 & 0.02832 & + & + & \\
\hline Cyprinid Richness & 5,27 & 2.626 & 0.2026 & 0.04644 & + & & \\
\hline Tolerant Cyprinid Richness & 5,27 & 2.997 & 0.2378 & 0.02805 & + & & \\
\hline Tolerant Species Richness & 5,27 & 2.324 & 0.1714 & 0.07 & + & & \\
\hline Ephemeroptera Cond & 5,27 & 4.68 & 0.3802 & 0.00375 & + & & \\
\hline Ephemeroptera DA & 5,27 & 2.694 & 0.2093 & 0.04228 & + & & \\
\hline Total Fish Biomass DA & 5,27 & 13.01 & 0.6523 & $<0.001$ & + & + & + \\
\hline Fish Diversity DA & 5,27 & 6.17 & 0.4468 & $<0.001$ & + & + & \\
\hline Game Fish Abundance DA & 5,27 & 10.74 & 0.611 & $<0.001$ & + & + & + \\
\hline Invertivore richness DA & 5,27 & 14.09 & 0.678 & $<0.001$ & & + & \\
\hline Cyprinid Richness -BND\&SEAT DA & 5,27 & 4.59 & 0.367 & 0.003 & & + & \\
\hline
\end{tabular}




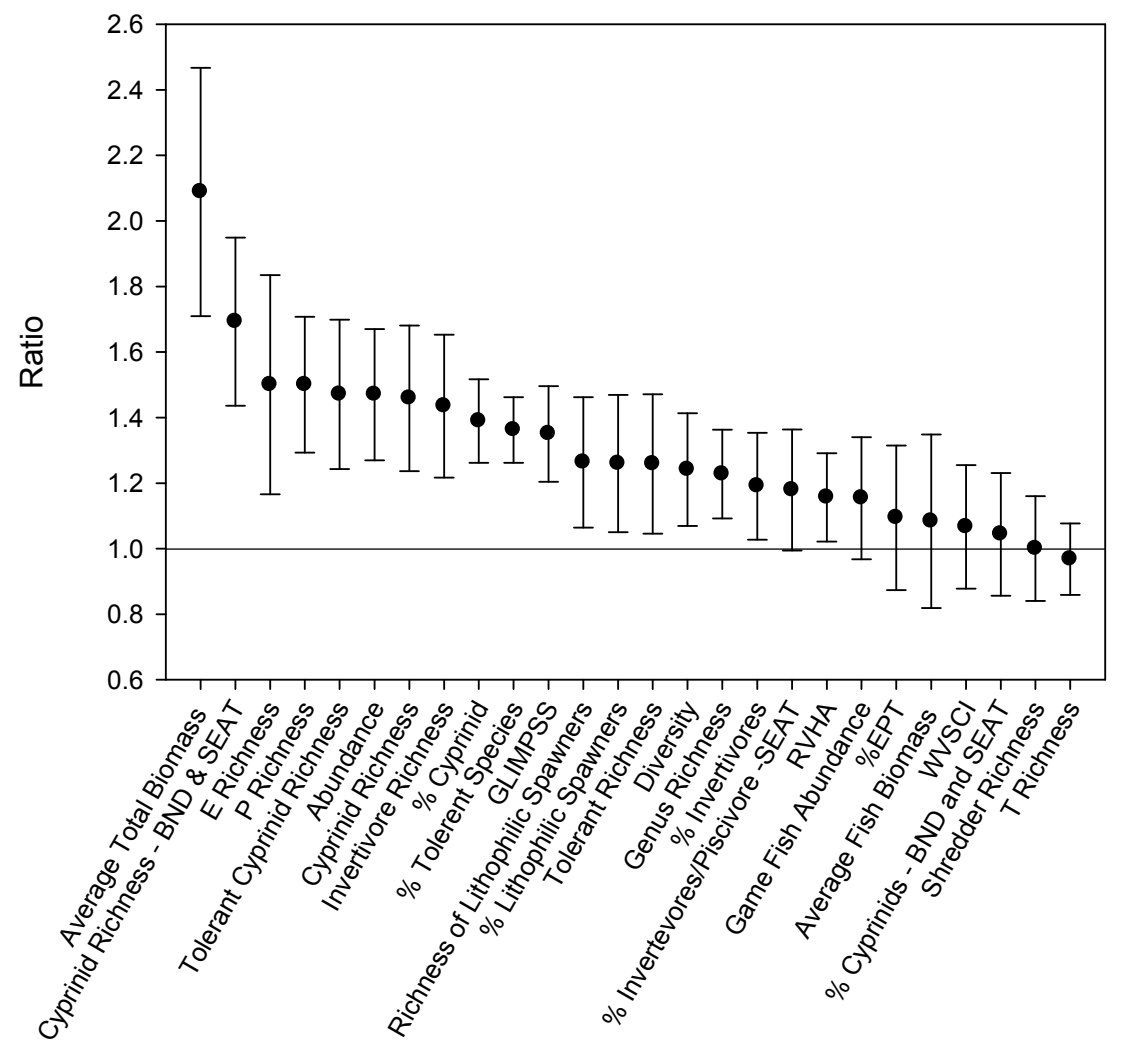

Figure 4. Change in metrics shown as a ratio between mitigated site and control stream with standard errors. 
CHAPTER 4: BENEFITS AND LIMITATION OF STREAM RESTORATION IN THE MOUNTAINTOP MINING REGION OF WEST VIRGINIA

Eric Miller* and J. Todd Petty

School of Natural Resources, West Virginia University, Morgantown, WV 26506

${ }^{*}$ Corresponding Author: Emiller9@mix.wvu.edu 


\section{Abstract}

In southern West Virginia, stream restoration has grown exponentially. This growth is largely due to state and federal requirements to offset impacts from large scale surface mining. Off-site mitigation is extremely common, because most streams within the mine boundaries are buried or severely altered. Currently, little is known about benefits and little is done to help decision makers choose sites for mitigation. Our study examined a large main-stem river and 14 restoration projects across a range of drainage areas and chemical constraints. We found that large rivers successfully increase habitat complexity, fish biomass, and Catastomidae (suckers) abundance. In addition, we found increases in cobble/gravel substrate in a localized $40 \mathrm{~m}$ reach centered on structure construction. However, little change was observed in reach-scale substrate and macroinvertebrates. Sediment aggradation at older structures was also observed, suggesting that continued maintenance of restoration projects may be necessary. Across our 14 sites, regardless of drainage area and chemical context, we found that streams increase in physical habitat. Multimetric fish and macroinvertebrate indexes of biotic integrity (IBI's) were used to determine change in biological community. Our results indicate that sites $<50 \mathrm{~km}^{2}$ in drainage area and $<1000 \mu \mathrm{s} / \mathrm{cm}$ in electrical conductance had the greatest increase in IBI scores. We recommend that, on large rivers, structures be placed closer to one another to potentially create an additive effect and expose more cobble/gravel over a larger reach. We also recommend that smaller scale projects be implemented on streams $<50 \mathrm{~km}^{2}$ in drainage areas and $<1000$ 
$\mu \mathrm{s} / \mathrm{cm}$ in electrical conductivity followed by a site reconnaissance to determine if the site would benefit from physical restoration.

Key words: Stream Restoration, Natural Channel Design, Synthesis, Mountain-top removal and valley fill mining 


\section{Introduction}

In the past few decades, the demand for stream restoration in central Appalachia has increased due to the negative effects of mountain top mining in the region (Palmer and Hondula 2014). Compensatory stream mitigation can be either on-site (within mine permit boundaries) or off-site (removed from the mine), and is used to offset the impacts mining has on aquatic ecosystems (Palmer and Hondula 2014). Despite the growing number of mitigation projects in the southern coalfields of West Virginia, little is known about the success or failure of these projects. Furthermore, permits for mitigation sites are granted with little or no consideration of constraints on the stream (personal correspondence with Dennis Stottlmyer and ACOE). In a region plagued with largescale landscape changes, stream side contained development, and limited restoration funds, using knowledge from previous projects may optimize success rates.

Stream mitigation can be split into two major categories: chemical and physical (Lake et al. 2007). Typically, the goal of physical stream mitigation projects is to improve local ecosystem processes through improved physical habitat stability and complexity, while maintaining the integrity of the system downstream (Giller 2005). Physical stream restoration has become synonymous with natural channel design (NCD) (Simon et al. 2007). NCD structures use engineering, geological, and biological principles to improve the hydrology, habitat, and aesthetics of a stream, while considering current and future conditions of the watershed and its surrounding landscape (Rosgen 1994). The NCD approach uses regional reference streams as a model for restoring and maintaining natural stream functions in degraded reaches (WNRCS 2004). Also, NCD structures 
use bankfull measurements to predict the natural tendencies of the river. Thus, structures designed from natural materials are installed in-stream to stimulate and maintain this behavior. Goals for in-stream NCD structures range greatly, but Rosgen (2001) states that structures should improve streambed complexity, fish habitat, and biodiversity.

Fish and macroinvertebrate communities have been used as bioindicators of disturbance because of their chemical, physical, and biological sensitivities (Holt and Miller 2011, Moerke and Lamberti 2003). The community present is dependent on local and regional scales (Cheek et al. 2015). Local scales, such as channel units, temperature, substrate type, flow regime, etc., are what drive the presence or absence of certain fish species from an available community (Delong et al. 2011). Regional, meta-community processes, such as landuse, swim distance, and physiological constraints affect the community that will be found (Anderson et al. 2015). Stream restoration often works under an assumption that altering local characteristics of a stream will change the fish and macroinvertebrate community, and often neglect the constraints that may be present. Hilderbrand (2005) describes the "field of dreams myth" in which stream restoration will attract fish and macroinvertebrates, just by simply building it. We have worked under this myth for many years and are slowly beginning to take a holistic approach to stream restoration.

Measuring fish and macroinvertebrate response to in-stream structures has had highly variable results (Louhi et al. 2011, Violin et al. 2011, and Koljonen et al. 2013). This 
variability can be caused by many factors; such as poor site selection of the mitigation project. Poor site selection can be described as a site that is impaired chemically, due to local or regional effects, causing physical modification to have no measureable results on the biota. Poor site selection has been seen in West Virginia, Virginia, and Kentucky as mitigation used to offset the impacts of mining (Palmer and Hondula 2014). There has been minimal work done to help decision makers on proper site selection.

Understanding the ecological benefits and the shortcomings of stream mitigation is essential to creating projects with the broadest impacts. Additionally, filling the knowledge gap concerning the effects of large river restoration can lead to more successful reaches on a river with over $40 \mathrm{~km}$, and growing, of restoration efforts. Currently in southern West Virginia, stream mitigation projects are placed at the discretion of government and industry officials and practitioners. Due to the major increase in projects (>100 in 10 years), using prior results to help future site selection has the potential to greatly improve mitigation success. Presently anecdotal evidence is used for site selection (personal correspondence, Dennis Stottlemyer, Chris White, Jason White). Using empirical evidence gained from previous mitigation projects we can maximize the success of future mitigation projects. Hilderbrand et al. (2005) describe two myths associated with restoration ecology that often hinder the success of mitigation activities. First, the "carbon-copy" myth is the idea that we can restore a site to a previous undisturbed state. Second, the "cook book" myth is described as the assumption that if a specific restoration activity works at one site, it will work at another. We are not expecting similar outcomes as other projects; we are using empirical data to 
screen future sites, both on small and large rivers. The objectives of this chapter were: 1- synthesizes major results from previous chapters 2- create simple guidelines for future restoration projects based on these results.

\section{Physical Responses on a Large River}

Little is known about the response of large rivers to in-stream restoration (Roni 2005). Consequently, a large-scale restoration project in the intensively mined, southern West Virginia was studied for five years. The Little Coal River drains $994 \mathrm{~km}^{2}$ of steep forested topography and is mainly comprised of sand bottom. The sandy substrate has been attributed to parent material, legacy activities, road construction, and mountaintop mining. Regardless of the source, the sand has created homogeneous streambed with little exposed boulders, cobble, or gravel. To combat the negative effects of the sand substrate, the West Virginia Department of Environmental Protection (WVDEP) has installed a series of natural channel design structures at a cost exceeding $\$ 3 \mathrm{M}$. The physical goals of the structures were to; reduce sand substrate and increase streambed complexity (Chapter 1$)$.

To assess the goals of reducing sand substrate and increase streambed complexity, we conducted a study that included pre-construction data. Our assessment included extensive sediment mapping, longitudinal profiles, cross-sectional profiles, and thalweg measurements (Chapter 1). The study was conducted for five years with 2009 being 
pre-construction. Our study reach contained three structures and was $\sim 1000 \mathrm{~m}$ in length.

\section{Effects of restoration on depth and river sediment composition is significant at a localized scale, but not at a reach scale.}

We found that substrate did not change over the reach scale. However, we did detect localized shifts in substrate from sand dominated to cobble and gravel. This local shift of exposed cobble/gravel was an area centered on each structure and was $\sim 40 \mathrm{~m}$ in length. Additionally, depth, at the reach scale, was not different compared to preconstruction (Figure 1).

\section{Restoration increases streambed complexity and fish habitat.}

We found newly developed deep scour pools beneath each structure. Based on longitudinal profiles streambed complexity increased by $80 \%$ the first year post construction and has stabilized around $+50 \%$ (Figure 1). Fish habitat has increased in the form of distance to fish cover. Post-construction, a fish would have to travel about half the distance to find cover compared to pre-construction (Figure 1).

One of the main goals of these structures was to reduce the amount of sand. We did not detect a reduction in sand over the reach scale, however there were localized decreases. The $40 \mathrm{~m}$ area of stream may have an additive effect. We suggest placing structures closer to one another so that the decrease in sand is more evident. Discussed in Chapter 1, we found areas that may be aggregating. Older structures may 
require maintenance/monitoring program to expand the life span of structures. Millions of dollars have been spent on this project. For benefits to persist, we suggest maintaining the scour pools in an effort to preserve streambed complexity. A limitation to this study is that we only studied a single river. Projects of that scale do not exist; therefore we cannot say if similar results would be found.

\section{Biological Responses on a Large River}

The science of stream restoration has exponentially grown in the United States since the mid-1980s (Bernhardt et al 2005). Although the number of projects has grown, as well as associated studies, there are still knowledge gaps. Restoration projects on large rivers are rare; therefore, the biological benefits are unknown worldwide. The Little Coal River, in the coalfields of West Virginia, has been the subject of millions of dollars in stream restoration activities. The biological goal of the projects was to increase biodiversity. We performed a 6 year study to assess the effects of in-stream structures on fish and benthic macroinvertebrate assemblages (Chapter 2).

\section{Gamefish abundance decreased, while biomass and Catastomidaes increase.}

The first year of our study was pre-construction; therefore, we were able to make comparisons from pre- to 5 years post-construction. We found that total fish abundance decreased and was consistently lower every year post-construction, except for 2013 , the year after a drought (Figure 2). Gamefish abundance has been lower every year post-construction. Average fish biomass decreased initially post construction and has 
continued to increase every year. Since abundance is decreasing but biomass is increasing, it leads us to believe larger, no gamefish are moving into these newly developed deep pools. Catastomidaes (suckers) have shown an increase post construction (Figure 2).

\section{Restoration had no significant effect on benthic macroinvertebrates}

We found that benthic macroinvertebrates showed little effect to the construction of these structures. The primary habitat used by benthic macroinvertebrates is cobble/gravel and since these structures did not expose more usable substrate, the macroinvertebrates are still habitat limited.

We discovered no new species of fish post-construction. It appears that the structures are re-sorting fish, not attracting new species. The Little Coal River may have chemical stressors present that would not allow more intolerant species to immigrate.

Furthermore, the newly developed deep scour pools seem to be attracting large suckers. Anecdotally, the structures seem to be attracting fishermen. We believe one possible hypothesis for the decrease in gamefish in due to newly founded fishing pressure. Although we have no data to test this hypothesis, there was a clear increase in boating, swimming, and fishing activity on the river, post-construction. Just as in the

physical changes section, a limitation of this project is sample size. Because projects of this size do not exist, we have no comparisons to it; therefore, it is unknown whether these results would be found on other projects of this size. 


\section{Physical Responses Over a Range of Drainage Areas and Water Qualities}

Due to the severe alteration mountaintop mining has on streams, southern West Virginia has become a concentrated area of stream restoration projects. For the amount of projects (>100 in 10 years) there is little known about the benefits. We examined 14 projects ranging in drainage areas $\left(0.8-220 \mathrm{~km}^{2}\right)$ and chemical constraints (electrical conductivity $220-2550 \mu \mathrm{s} / \mathrm{cm}$ ) to determine the physical benefits. We used the Environmental Protection Agency's Rapid Visual Habitat Assessment (RVHA, Barbour et al. 1999) and compared a mitigated reach to an unrestored upstream reach (Chapter 3).

\section{Physical habitat increased despite size and chemical constraints.}

The multimetric scaling system of RVHA found that overall habitat increased, on average by $20 \%$ (Figure 3). On average there were large increases in velocity depth regime, epifaunal substrate and available cover, and channel flow status with restoration activities (Figure 3). However, there were metrics, which on average decreased relative to unrestored reaches. Vegetative protection decreased by $\sim 10 \%$ in restored reaches, due to access roads being cut into the riparian zone. The frequency of riffles in restored reaches decreased by $\sim 20 \%$ because restoration activities typically create deeper pools. Also, not surprisingly, channel alterations are higher in restored reaches as compared to their upstream counterparts (Figure 3).

There seems to be no clear pattern with respect chemical constraints of a stream and the increase in RVHA score (Figure 4). However, there does seem to be a pattern with 
respect to drainage area. We found four sites that the upstream unrestored reach had a higher RVHA score than the restored reach. All of those sites were below $50 \mathrm{~km}^{2}$. Interestingly, three of those sites were below an electrical conductivity of $1000 \mu \mathrm{s} / \mathrm{cm}$ (Figure 4). Since they had relatively decent water quality, they could have been closer to reference stream conditions and didn't need physical habitat restoration.

Although we only studied 14 sites we found that, on average, regardless of size and chemical context, habitat is increased. The act of in-stream restoration uses heavy equipment and greatly modifies the streambed. We have shown that, on average, we can increases stream complexity by $\sim 20 \%$. There are, however, sites that actually decreased in habitat. $30 \%$ of our restored sites had lower RVHA score than upstream; therefore, all streams should be carefully considered when attempting to restore them because it may be more harmful than helpful.

\section{Biological Responses Over a Range of Drainage Areas and Water Qualities}

Prior to this research there had been no systematic study to assess the effects of stream restoration in the southern coalfields of West Virginia. In addition to understanding the physical benefits from stream restoration we examined the biological effects. In order to assess the biological benefits of stream restoration, we used fish and macroinvertebrate indexes of biotic integrity (IBI's). IBl's score streams from 0 100 based on the community assemblages (Anderson 2015). We examined fish and 
macroinvertebrate (WVSCI) IBI's through the same study design at the same sites as the physical metrics (Chapter 3).

\section{Drainage area and chemical context constrain macroinvertebrates and fish response.}

There were minimal changes to WVSCI scores due to in-stream restoration. The average increase in WVSCI was $\sim 10 \%$ and was variable across electrical conductivity (Figure 5). There were sites that had a $>30 \%$ increase in WVSCl score and those sites were below $1000 \mu \mathrm{s} / \mathrm{cm}$ in electrical conductivity (Figure 5). On average, sites with high electrical conductivity ( $>2000 \mu \mathrm{s} / \mathrm{cm}$ ) showed no change in WVSCI score after restoration (two of the points are directly under fish IBI points, Figure 5). Although the majority of our sites were below $50 \mathrm{~km}^{2}$ in drainage area, that is where we saw the greatest increase in fish IBI. The average was $\sim 40 \%$ increase in IBI score with some sites exceeding $70 \%$ in fish IBI score increase (Figure 5).

Based on multimetric fish and macroinvertebrate score IBl's, there are clear limitations to expected benefits based on size and chemical constraints. Our results suggest that sites show the highest benefit when they are less than $1000 \mu \mathrm{s} / \mathrm{cm}$ in electrical conductivity and less than $50 \mathrm{~km}^{2}$ in drainage area. $87 \%$ of the segment level watersheds in the Twelvepole Watershed met the 2 criteria (Figure 6). On average about $80 \%$ of all segment level watersheds met the criteria within each major HUC 8 watershed. Discussed in Chapter 3, we found that most sites increased in tolerant, 
abundant fish. To avoid this and potentially add intolerant fish to the assemblage, we suggest sites be selected based on their current chemical context and size.

\section{Socio-Economic Factor}

Although we measured only the physical and biological responses of stream restoration there was a clear human response that we observed at most projects. The public seems to have embraced stream restoration and most show a real enthusiasm about projects, regardless of biological benefits. During pre-construction sampling of the Little Coal River, not a single person was seen on the water. However, every year postconstruction, the river was filled with, kayakers, swimmers, campers, and fisherman. There are structures that can be accessed via automobile and these structures have become a favorite swimming hole for locals. Fire rings, rope swings, and makeshift log benches are seen at all these structures. At the intersection of Little Coal River Road and Interstate 119 sits a gas station. The owner of that gas station told us how happy he was because the restoration on the Little Coal River brought him costumers. He has even offered to pay for a permeant boat slip at the confluence of the Little and Big Coal Rivers.

We spoke with many land owners and citizens at our sites and not a single negative comment was said about the work. The communities have started to come together and have clean up days for the streams and host events associated with restored streams (i.e. tour de coal, buffalo creek days). Rick Steelhammer, a writer for the 
Charleston Gazette, has documented the Little Coal River many times and brought that information to the masses. The impact these structures have on the small community in Southern West Virginia is anecdotally great. With the continued support of the community, some of the equivocal results we saw in physical and biological results may change.

Madison Middle School is located on the Little Coal River in Boone County, West Virginia. The eighth grade class at the school won a national competition for their involvement on the restoration efforts of the Little Coal River. They won a $\$ 10,000$ grant to buy equipment and continue their research on the river. Graduate students from West Virginia University, volunteers from the Coal River Group, and WVDEP employees assisted students in surveying, fish and macroinvertebrate colleting and identification, computational skills, and many other things to help them in their future research.

\section{Conclusions}

Although we had a small sample size there are some clear patterns that emerged. Large river restoration increase complexity and habitat results in no changes to macroinvertebrates, and seems to re-sort fish communities. The fact that we observed no change in macroinvertebrate metrics suggests to us the system is still macroinvertebrate habitat limited. Macroinvertebrates prefer cobble/gravel substrate and since the structures are only exposing localized amounts of cobble/gravel, no reach 
scale differences are seen in macroinvertebrates. Potentially placing structures closer together may expand the area that decreases in sand substrate, and may lead to an increase in macroinvertebrate metrics. We observed an increase in large suckers with the newly developed pools and a decrease in game fish. The species of suckers that were discovered in the restored reach were also seen elsewhere in the river. The structures are designed to create deep scour pools beneath them, so it's no surprise that pool dwelling species have inhabited them. Expecting new fish species, not found throughout the river, to inhabit structures will only happen if water quality is addressed. The water quality of the Little Coal River may be such that intolerant, sensitive species cannot move into the newly formed habitat.

Smaller projects on average increase habitat, have minimal effect on macroinvertebrates, and increase fish IBI; however, context matters. Sites $<50 \mathrm{~km}^{2}$ and $<1000 \mu \mathrm{s} / \mathrm{cm}$ showed the greatest increase in fish and macroinvertebrate IBI. Our results show that we can increase habitat at most sites; however, there are some sites that simply don't need habitat restoration. We suggest that sites should be $<50 \mathrm{~km}^{2}$ and have an electrical conductivity of $<1000 \mu \mathrm{s} / \mathrm{cm}$ (which can be accurately predicted, Merriam et al. 2015) in order to be selected for restoration. Based on those criteria, after a site is chosen we recommend a reconnaissance to the site to determine if physical restoration is needed. Since the average increase in habitat is $\sim 20 \%$ we recommend that a site range in RVHA score from $50-70 \%$. 
The effects of these structures reach much further than just ecological. The economic, social, and aesthetic impacts seem to be well worth the investment of restoration projects. When public perception is that of southern West Virginians, with respect to restoration it has an additive effect. Educating the children of the region will foster a greater sense of pride and appreciation for the rivers. The public is becoming more involved with stream cleanup and overall stream health awareness; which greatly helps stream restoration. With the increase of public awareness and utilizing the drainage area and electrical conductivity screening process could make Southern West Virginia the example of successful stream restoration. 


\section{Literature Cited}

Anderson, A. 2015. Creating a fish index of biotic integrity for the state of West Virginia. Dissertation submitted to: West Virginia University.

Barbour, M. T., Gerritsen, J., Snyder, B. D., \& Stribling, J. B. (1999). Rapid bioassessment protocols for use in streams and wadeable rivers. USEPA, Washington.

Bernhardt, E. S., M. Palmer, J.D. Allan, G. Alexander, K. Barnas, S. Brooks, S...and E. Sudduth. 2005. Synthesizing U. S. river restoration efforts. Science(Washington), 308(5722):636-637.

Cheek, B. D., T.B. Grabowski, P.T. Bean, J.R. Groeschel, and S.J. Magnelia. 2015. Evaluating habitat associations of a fish assemblage at multiple spatial scales in a minimally disturbed stream using low-cost remote sensing. Aquatic Conservation: Marine and Freshwater Ecosystems.

Delong, M. D., J.H. Thorp, M.C. Thoms, and L.M. McIntosh. 2011. Trophic niche dimensions of fish communities as a function of historical hydrological conditions in a Plains river. River Systems, 19(3):177-187.

Giller, P. S. 2005. River restoration: seeking ecological standards. Editor's introduction. Journal of Applied Ecology 42(2):201-207.

Hilderbrand R.H., A.C. Watts, and A.M. Randle. 2005. The myths of restoration ecology. Ecology and Society, 10, (online) URL: http://www.ecologyandsociety.org/ vol10/iss1/art19/.

Holt, E. A. and S.W. Miller. 2011. Bioindicators: using organisms to measure environmental impacts. Nature Education Knowledge, 3(10):8.

Koljonen, S., A. Huusko, A. Mäki-Petäys, P. Louhi, and T. Muotka. 2013. Assessing Habitat Suitability for Juvenile Atlantic Salmon in Relation to In-Stream Restoration and Discharge Variability. Restoration Ecology, 21(3):344-352.

Lake, P. S., N. Bond, and P. Reich. 2007. Linking ecological theory with stream restoration. Freshwater Biology 52(4):597-615.

Louhi, P., H. Mykrä, R. Paavola, A. Huusko, T. Vehanen, A. Mäki-Petäys, and T. Muotka. 2011. Twenty years of stream restoration in Finland: little response by benthic macroinvertebrate communities. Ecological Applications, 21(6):1950-1961.

Merriam, E. R., J.T. Petty, M.P. Strager, A.E. Maxwell, and P.F. Ziemkiewicz. 2015. Complex contaminant mixtures in multi-stressor Appalachian riverscapes. Environmental Toxicology and Chemistry. 
Moerke, A. H. and G.A. Lamberti. 2003. Responses in fish community structure to restoration of two Indiana streams. North American Journal of Fisheries Management, 23(3):748-759.

Palmer, M. A and K.L. Hondula. 2014. Restoration as mitigation: analysis of stream mitigation for coal mining impacts in southern Appalachia. Environmental science \& technology, 48(18):10552-10560.

Roni, P. and E. Quimby. 2005. Monitoring stream and watershed restoration. CABI. Rosgen, D.L., 1994. A classification of natural rivers. Catena 22:169:199.

Rosgen, D. L. 2001. The cross-vane, w-weir and j-hook vane structures... their description, design and application for stream stabilization and river restoration. Amer. Assoc. Civil Engrs., Restoration Proceedings, Reno, Nevada.

Simon, A., M. Doyle. M. Kondolf, F.D. Shields Jr., B. Rhoads, and M. McPhillips, 2007. Critical Evaluation of How the Rosgen Classification and Associated "Natural Channel Design" Methods Fail to Integrate and Quantify Fluvial Processes and Channel Response. Journal of the American Water Resources Association 43(5):1117-1131.

Violin, C. R., P. Cada, E.B. Sudduth, B.A. Hassett, D.L. Penrose and E.S. Bernhardt. 2011. Effects of urbanization and urban stream restoration on the physical and biological structure of stream ecosystems. Ecological Applications, 21(6):19321949.

West Virginia Department of Environmental Protection, West Virginia Save Our Streams Advanced Stream Assessment Manual (Charleston, WV: West Virginia Department of Environmental Protection, Division of Water and Waste Management, 2004). 
Tables and Figures

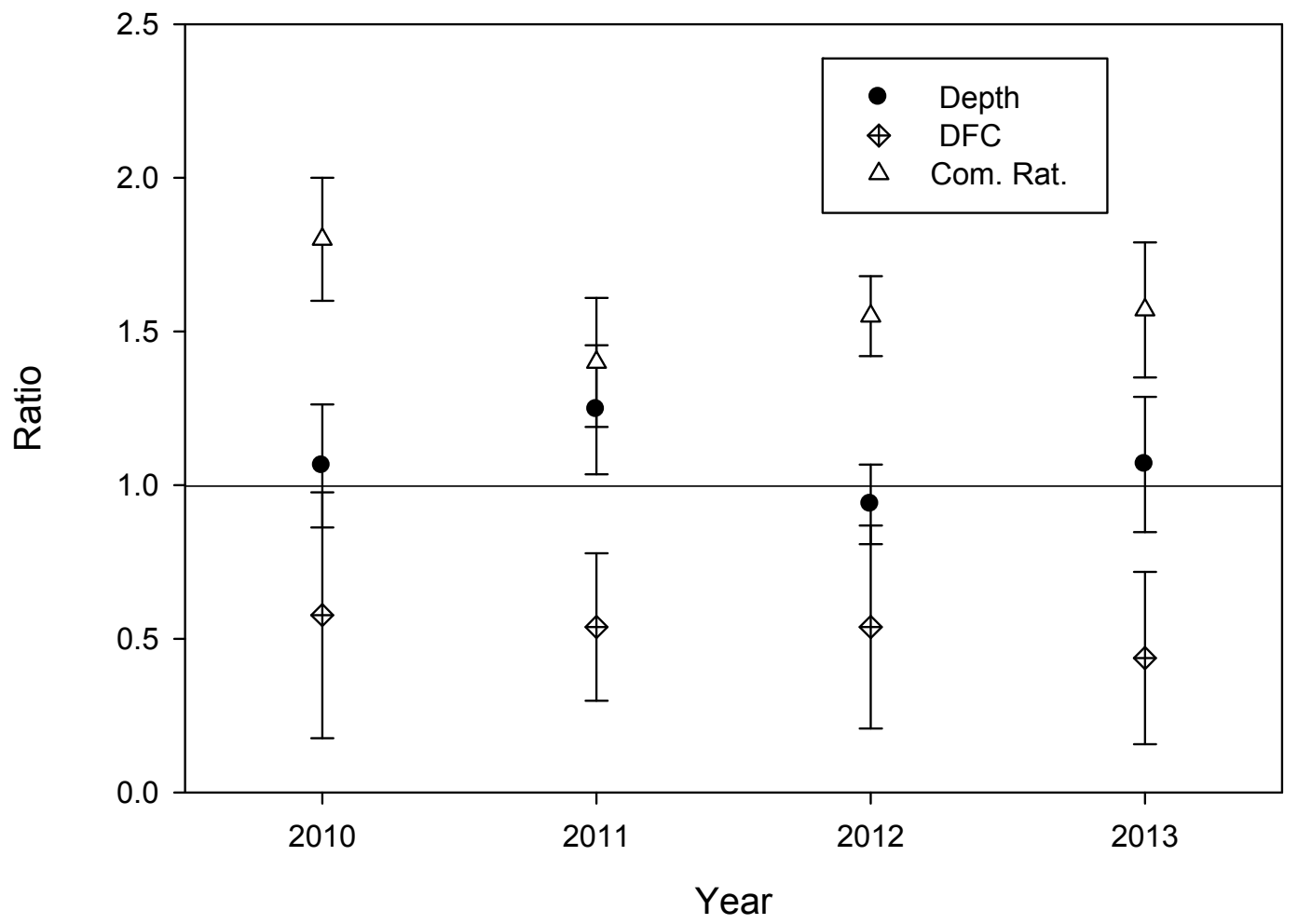

Figure 1. Ratios (SE) comparing physical metrics of each year to pre-construction (2009) on the Little Coal River. Depth = water depth, DFC= Distance to fish Cover, and Com. Rat. $=$ Complexity Ratio. 


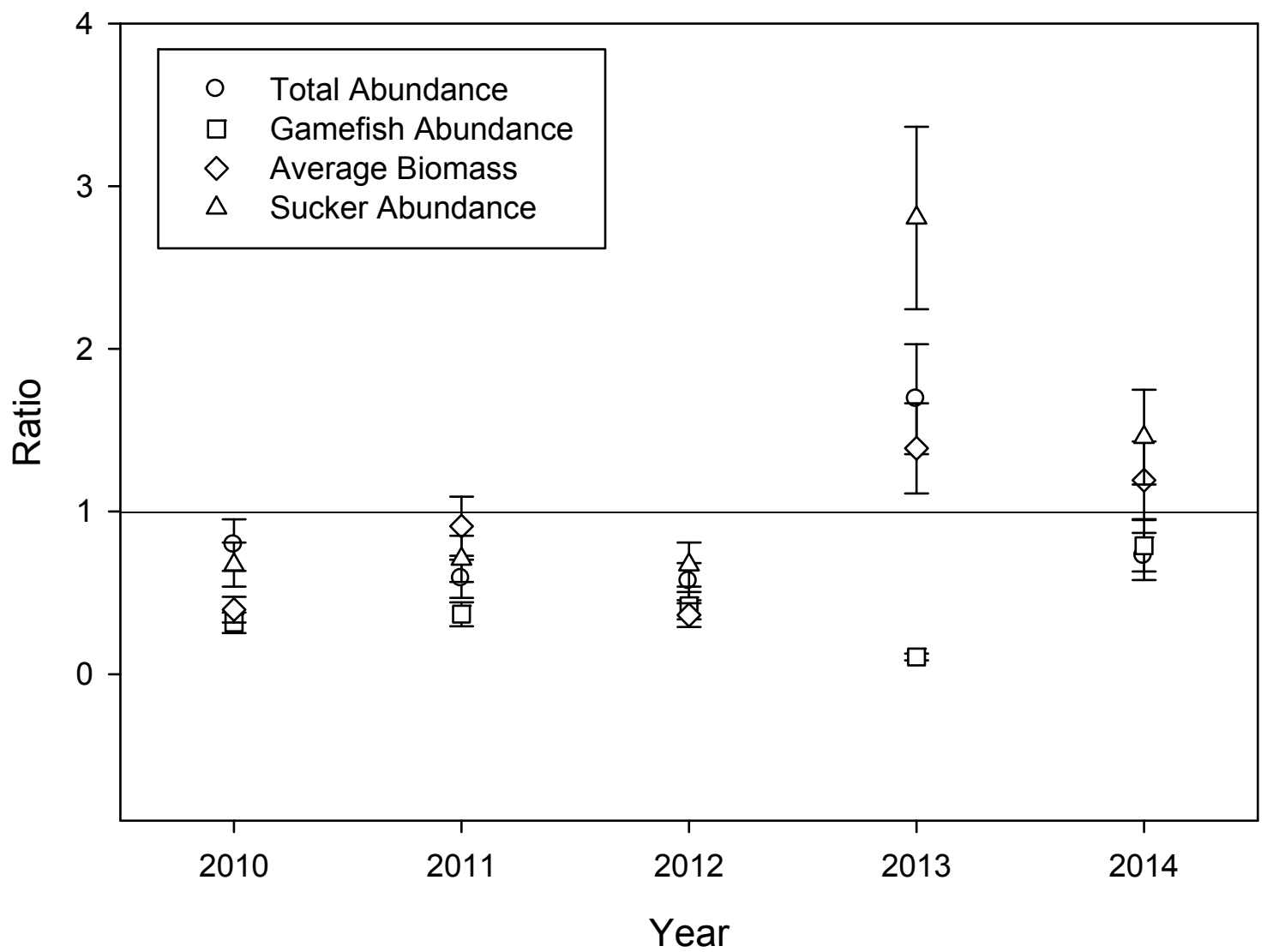

Figure 2. Ratios (SE) comparing fish metrics of each year to pre-construction (2009) on the Little Coal River. 


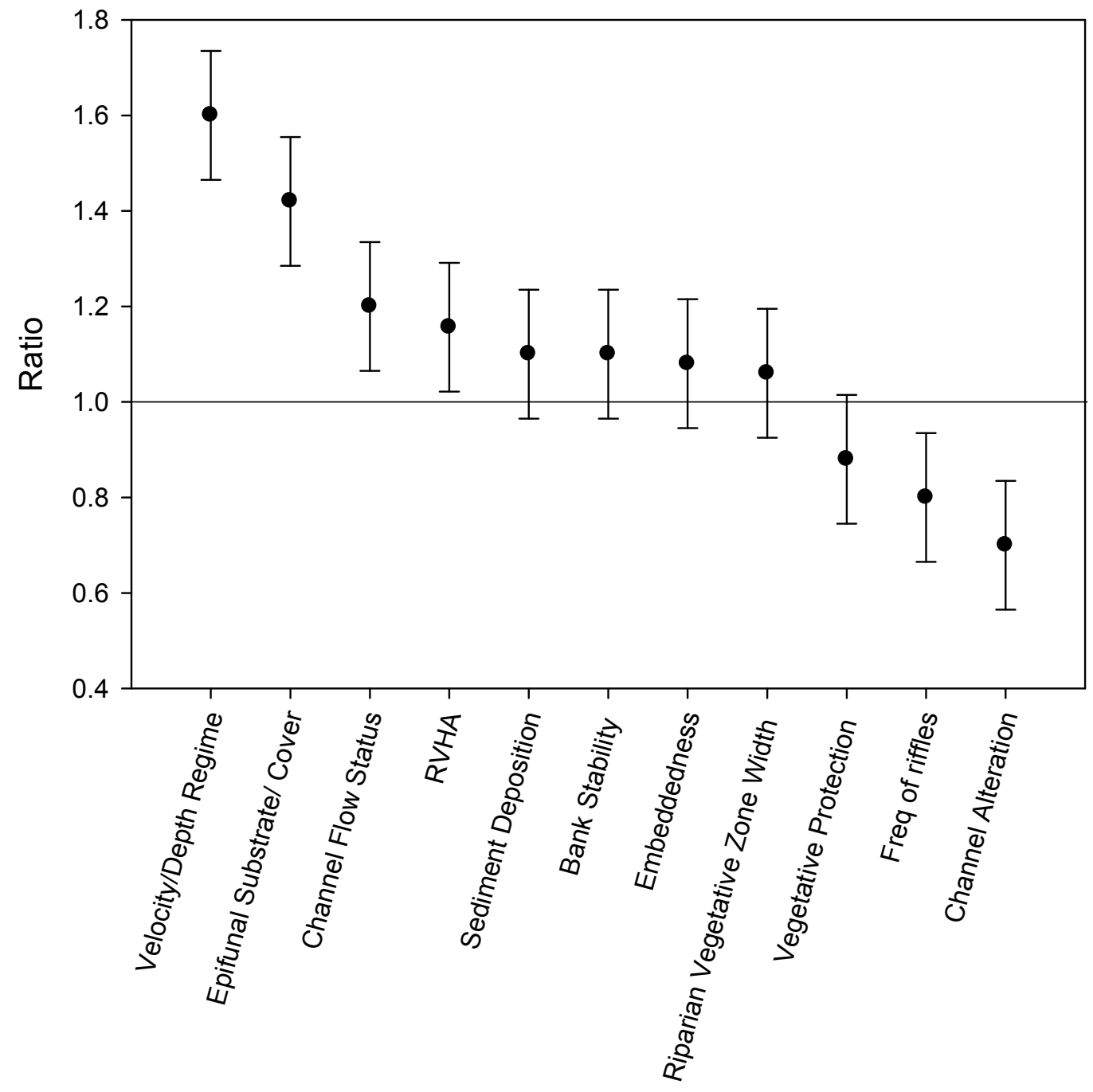

Figure 3. Average ratios (SE) comparing habitat metrics of mitigated reach to upstream control reaches. 
a.
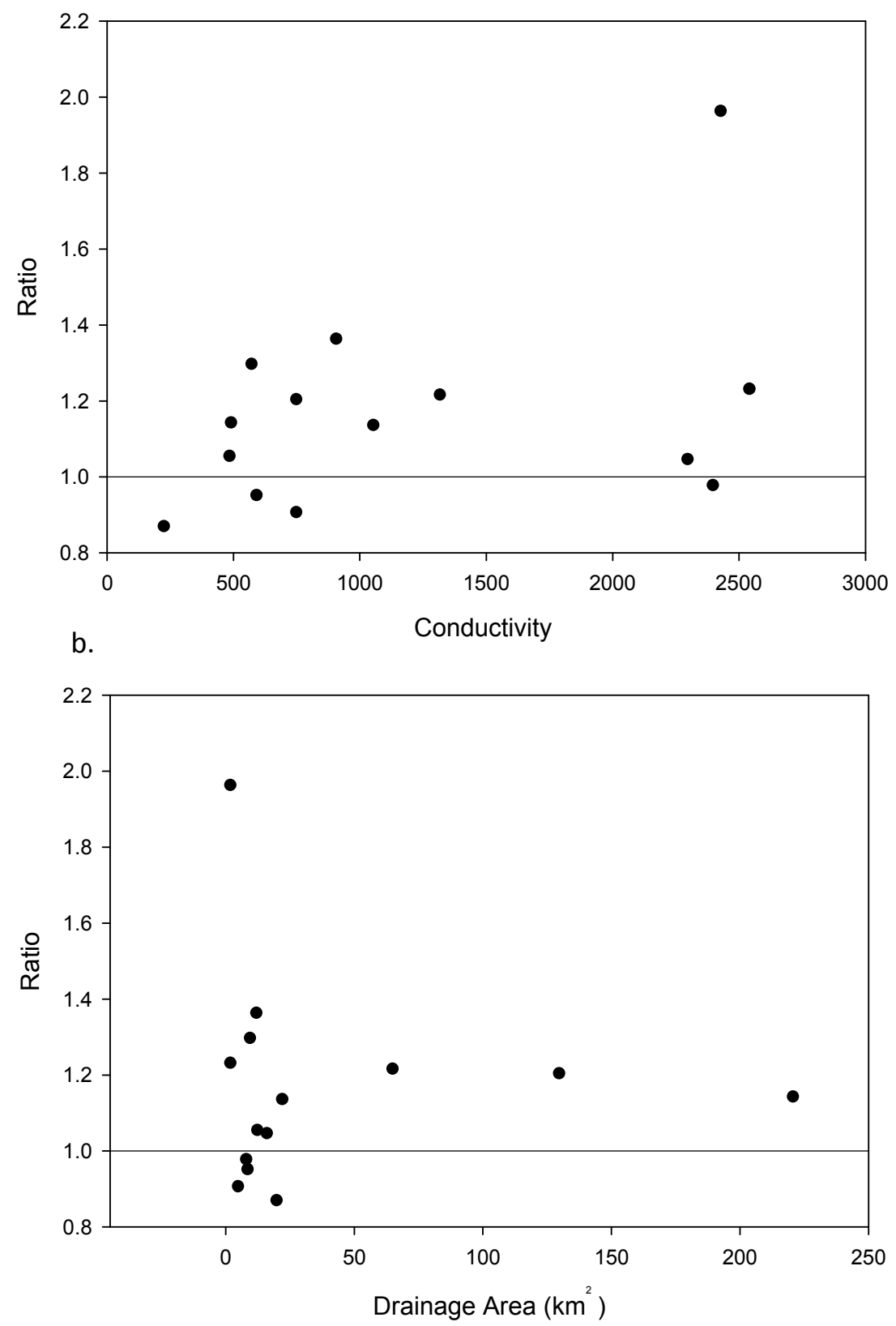

Figure 4. Ratios depicting change in RVHA with respect to a) conductivity and b) drainage area. 
a.

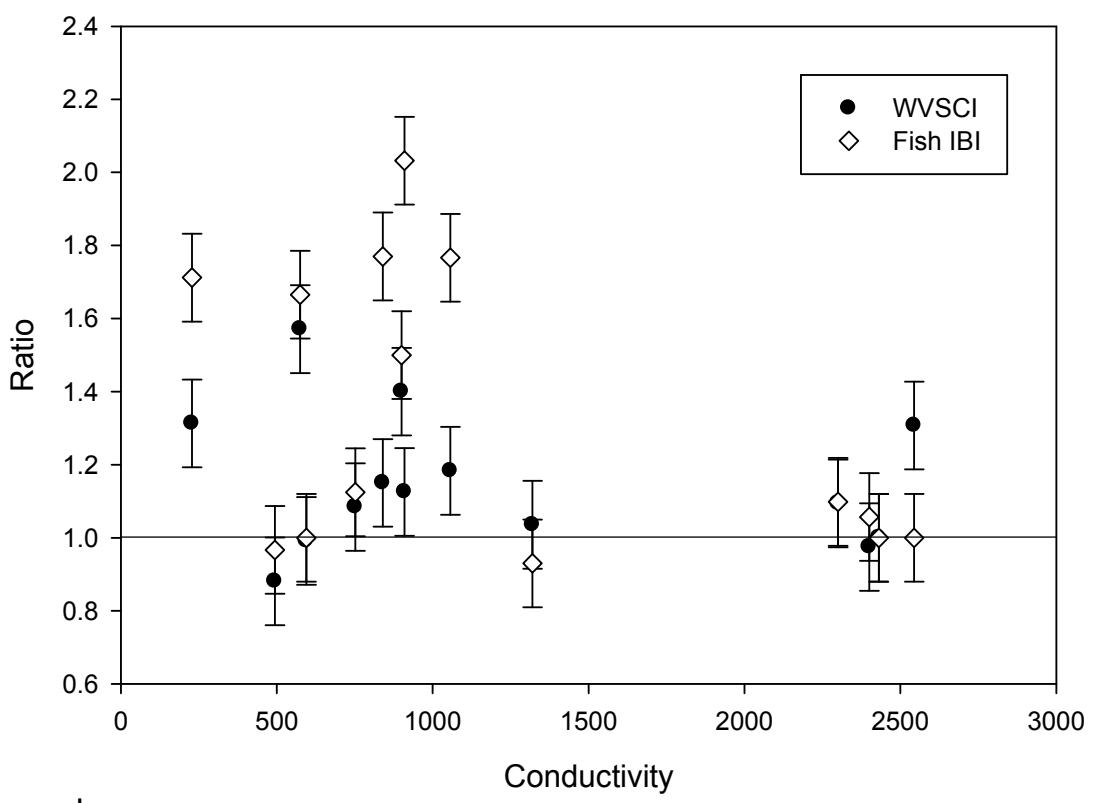

b.

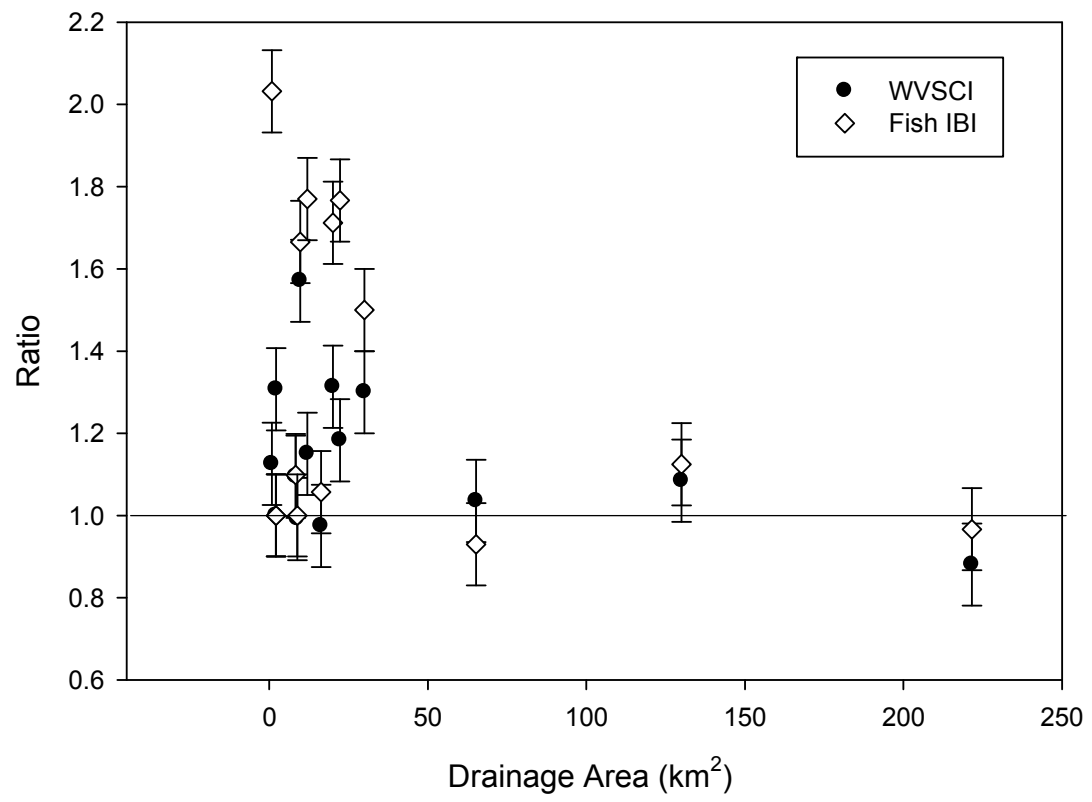

Figure 5. Ratios (SE) depicting change in WVSCl and Fish IBI score with respect to a) electrical conductivity and b) drainage area. 


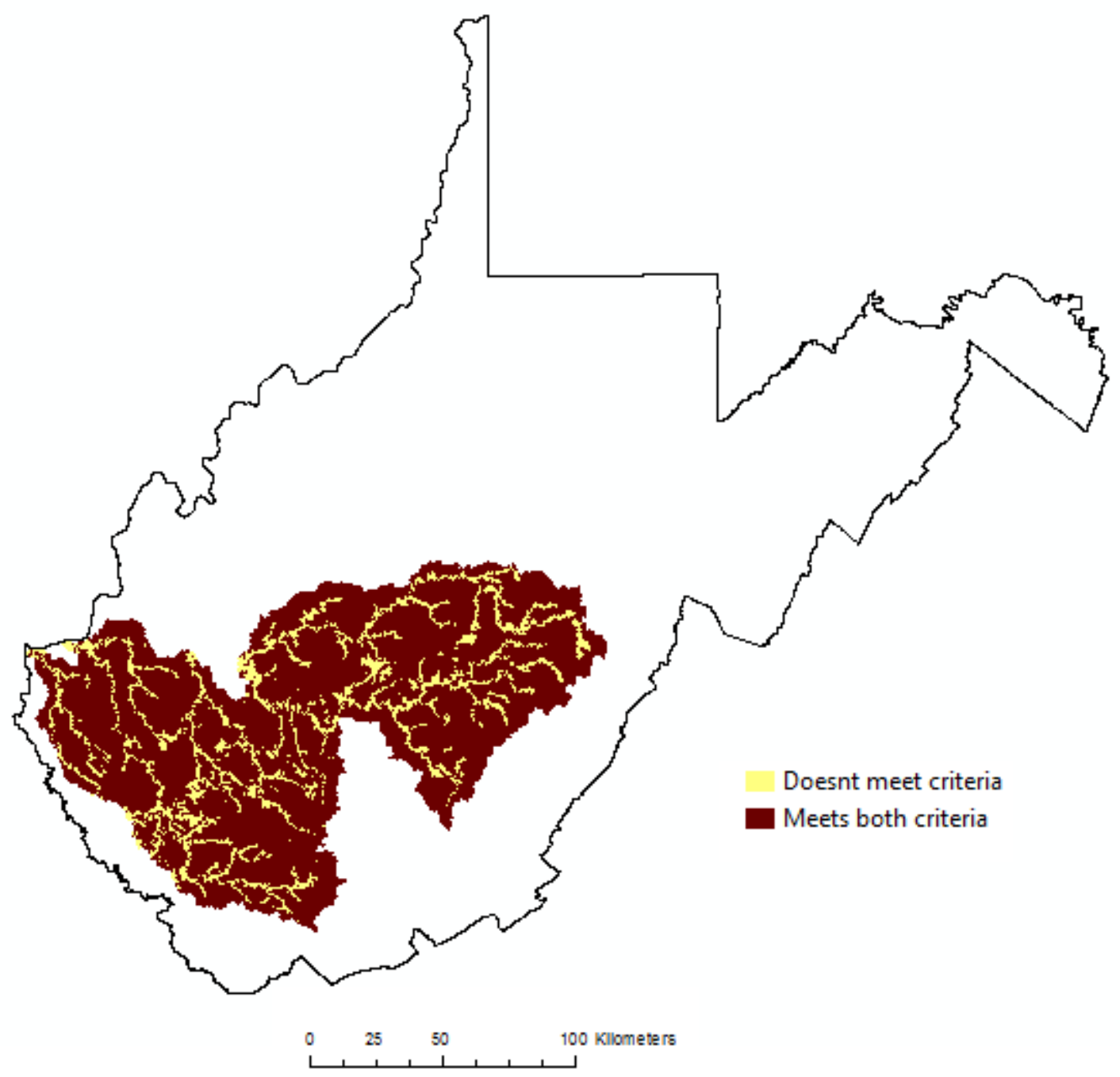

Figure 6. Map showing streams in the HUC12 watershed in the coalfields of West Virginia that meet the $<50 \mathrm{~km}^{2}$ and $<1000 \mu \mathrm{s} / \mathrm{cm}$ criteria. Electrical conductance was predicted based on Merriam et al. (2015). 


\section{Appendix A: Cross sectional surveys of the upper, middle, and lower reaches.}
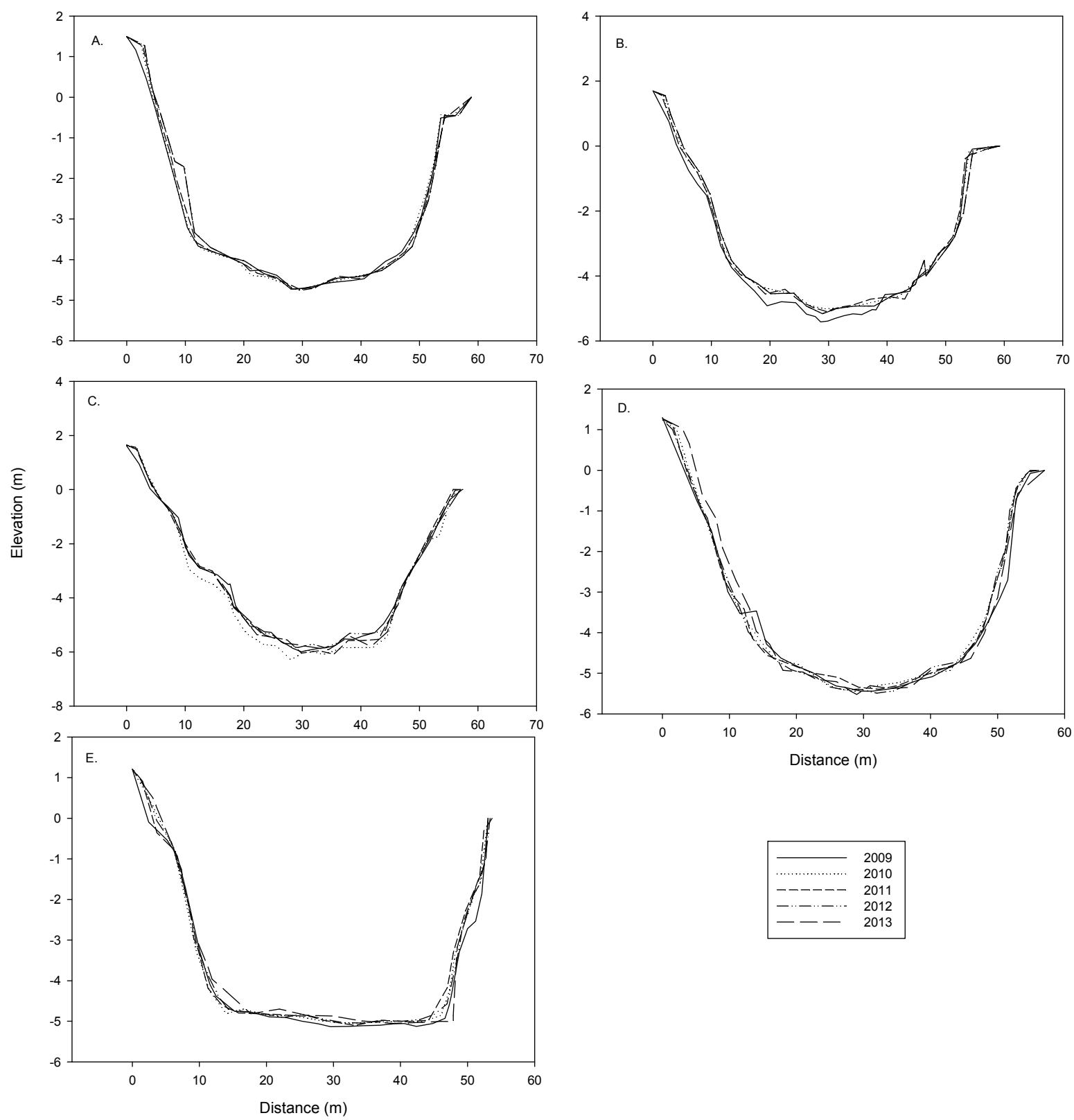

Figure 1. Cross sectional surveys from the $2^{\text {nd }}$ structure in the upper reach. $A$. is 30 meters upstream of the rootwad of the structure, B. is 15 meters upstream of the rootwad of the structure, $C$. is at the rootwad, D. is 15 meters below the rootwad, and $\mathrm{E}$. is 30 meters downstream. 

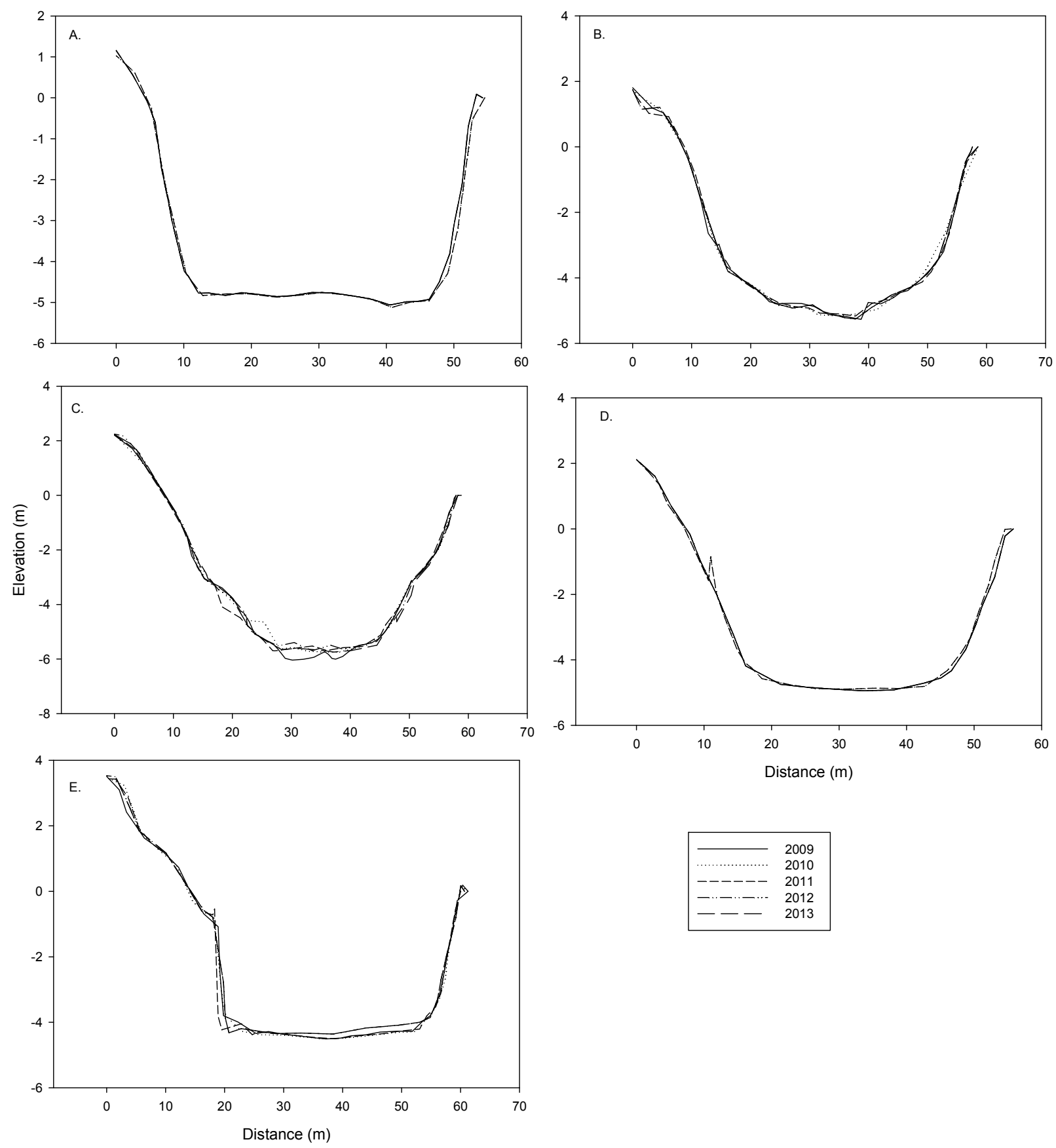

Figure 2. Cross sectional surveys from the $3^{\text {rd }}$ structure in the upper reach. A. is 30 meters upstream of the rootwad of the structure, B. is 15 meters upstream of the rootwad of the structure, $C$. is at the rootwad, D. is 15 meters below the rootwad, and $\mathrm{E}$. is 30 meters downstream. 

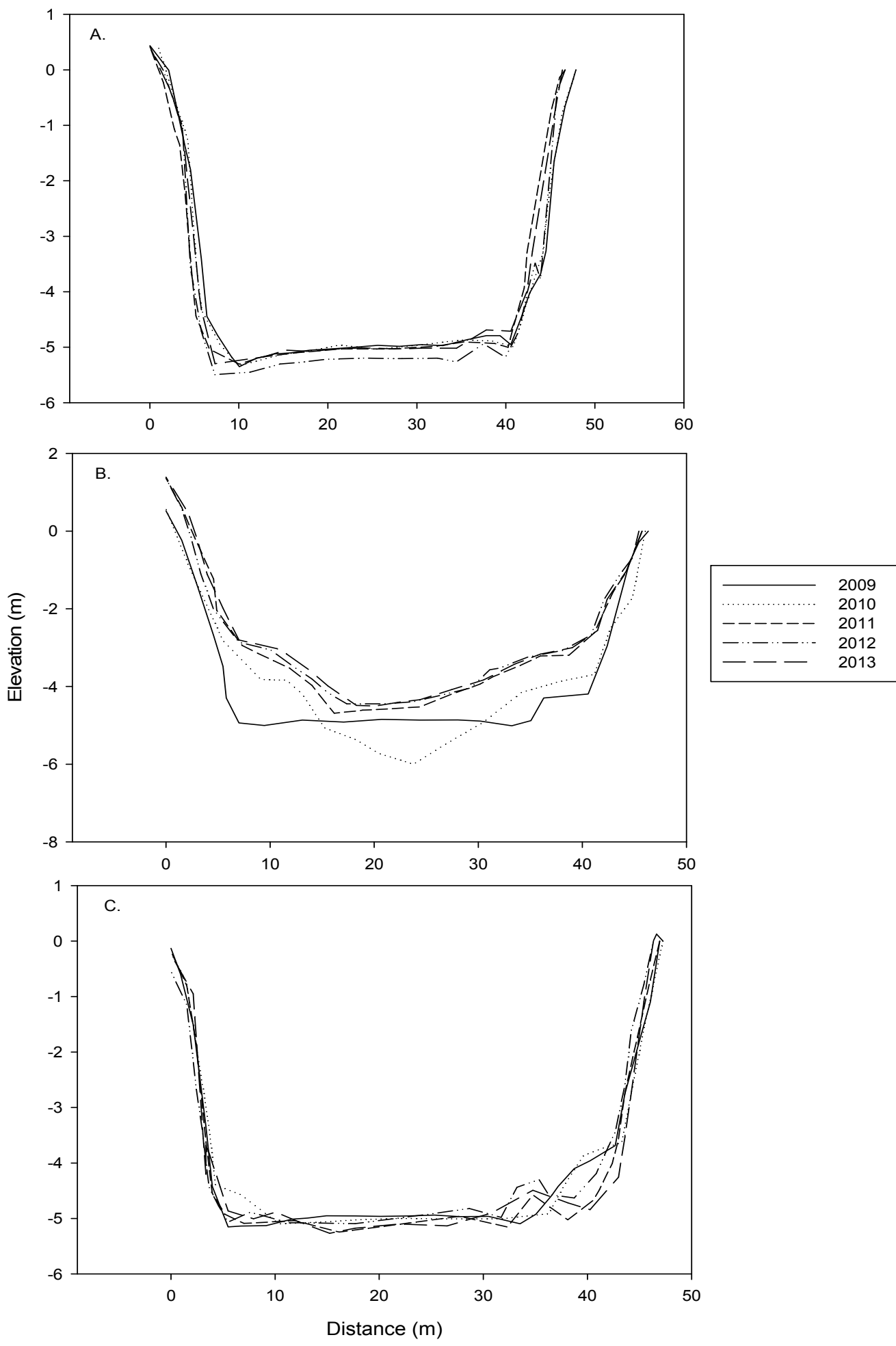

Figure 3. Cross sectional surveys of a structure in the lower reach. A. is 30 meters above the rootwad, $\mathrm{B}$. is at the rootwad, and $\mathrm{C}$. is 30 meters below the rootwad. 

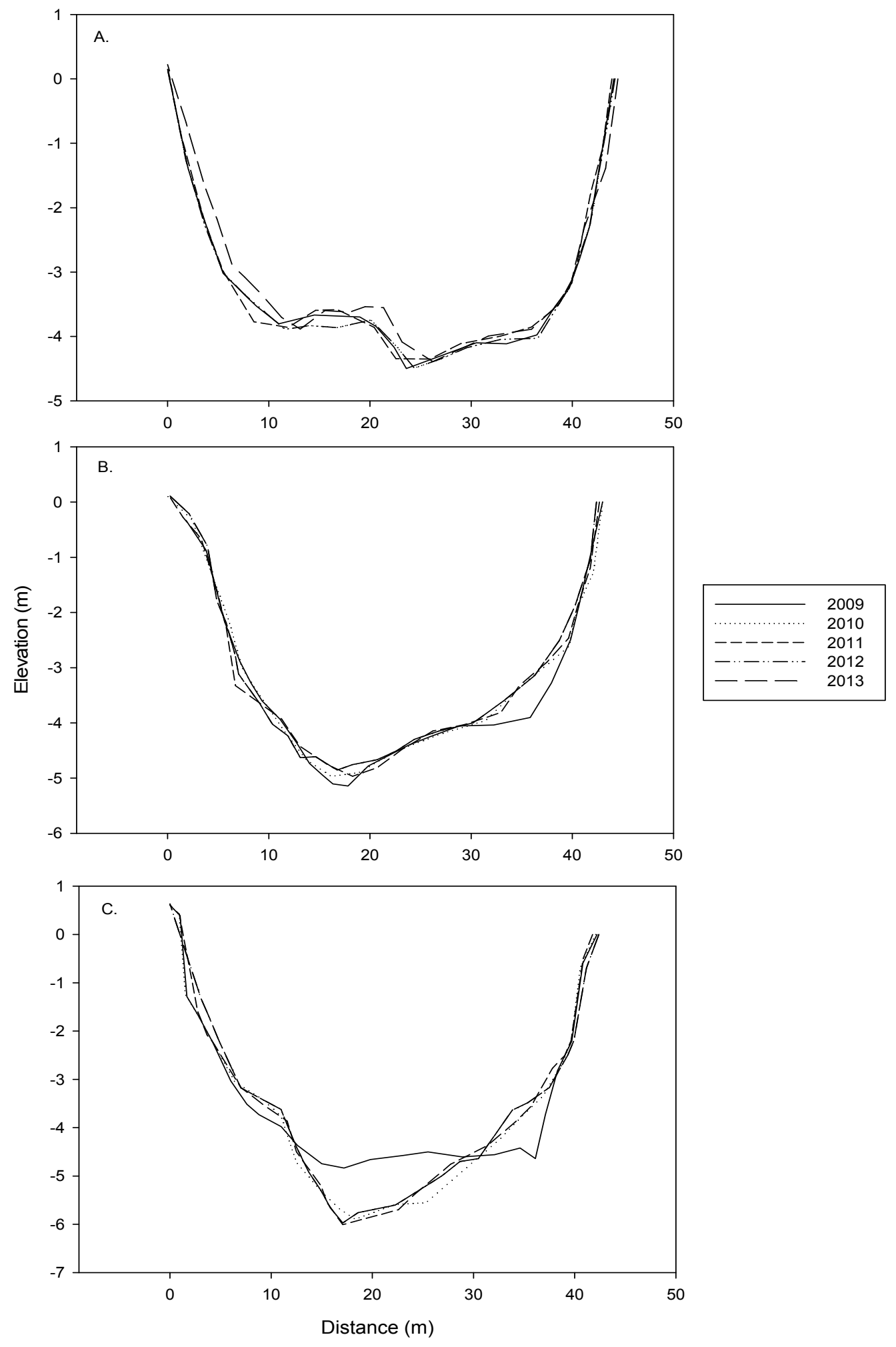

Figure 4. Cross sectional surveys of a structure in the lower reach. A. is 30 meters above the rootwad, $\mathrm{B}$. is at the rootwad, and $\mathrm{C}$. is 30 meters below the rootwad. 

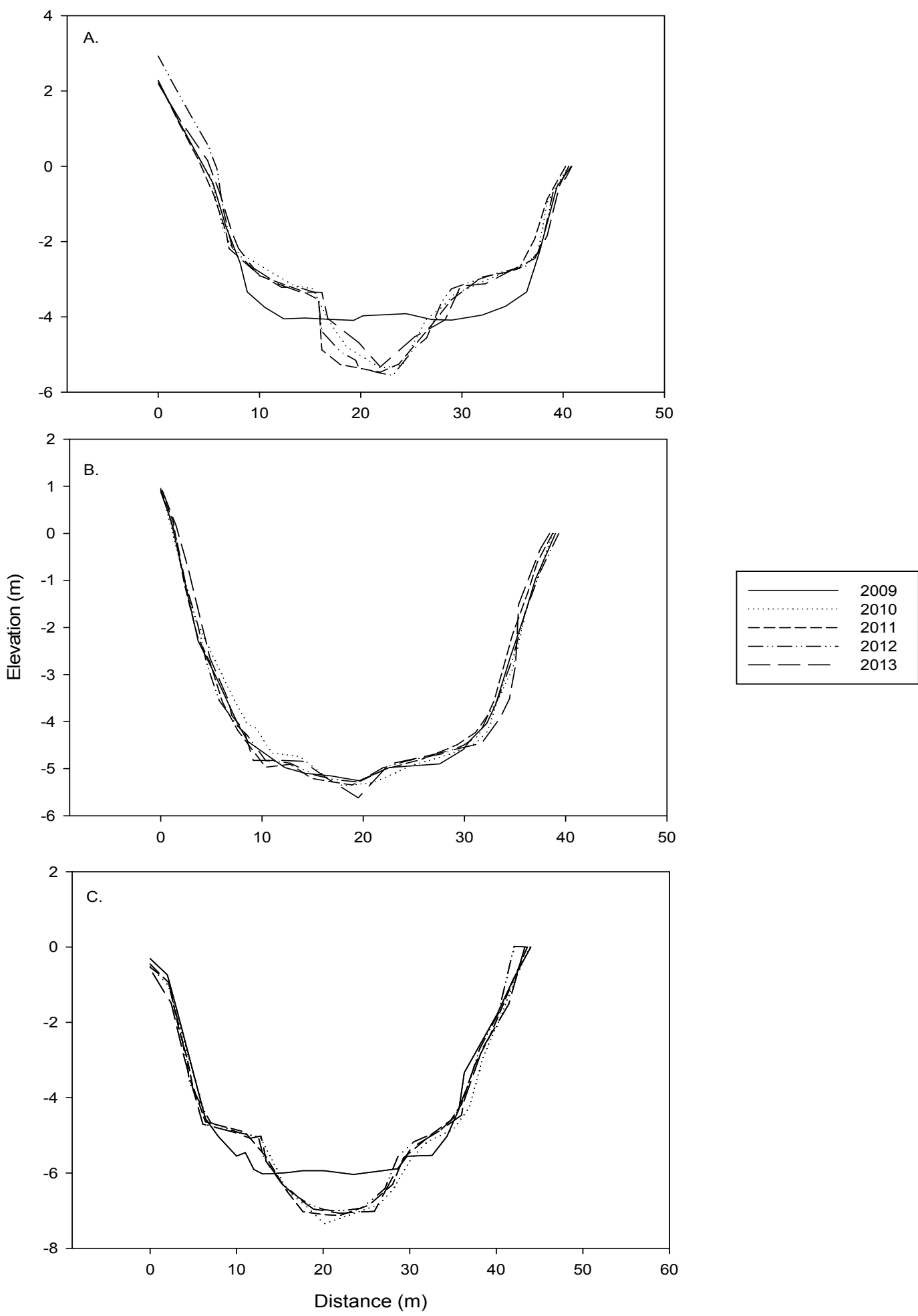

Figure 5. Cross sectional surveys of 2 structures in close proximity in the lower reach.

A. is at a rootwad, $B$. is 30 meters below and 30 meters above a rootwad, and $C$. is 30 at a rootwad. 

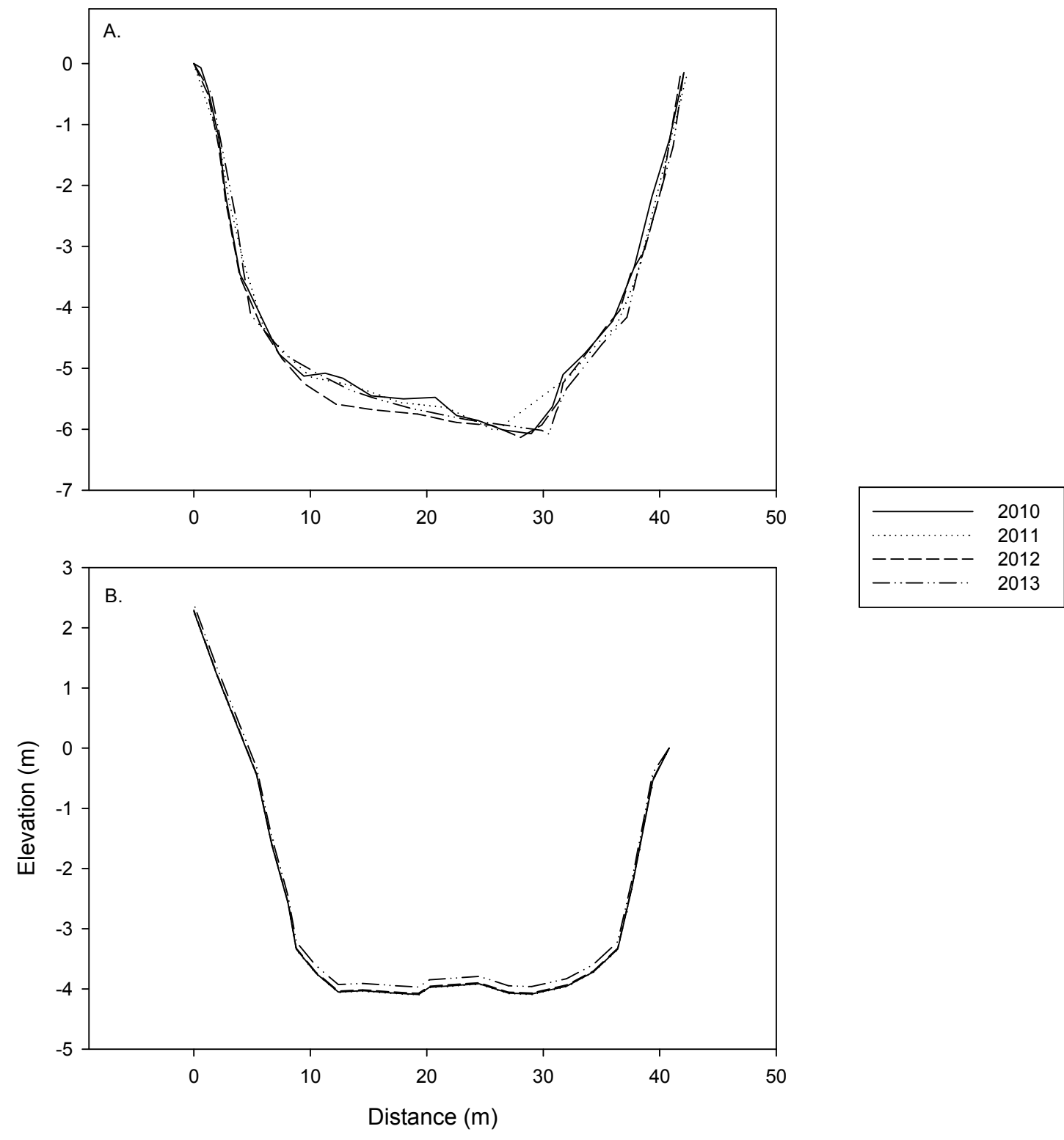

Figure 6. Cross sectional surveys from the middle reach. A. is a reference pool B. is a reference riffle. 